Portland State University

PDXScholar

\title{
A Tale of Three Sisters: Reconstructing the Holocene glacial history and paleoclimate record at Three Sisters Volcanoes, Oregon, United States
}

Shaun Andrew Marcott

Portland State University

Follow this and additional works at: https://pdxscholar.library.pdx.edu/open_access_etds

Part of the Geology Commons, and the Glaciology Commons Let us know how access to this document benefits you.

\section{Recommended Citation}

Marcott, Shaun Andrew, "A Tale of Three Sisters: Reconstructing the Holocene glacial history and paleoclimate record at Three Sisters Volcanoes, Oregon, United States" (2005). Dissertations and Theses. Paper 3386.

https://doi.org/10.15760/etd.5275

This Thesis is brought to you for free and open access. It has been accepted for inclusion in Dissertations and Theses by an authorized administrator of PDXScholar. Please contact us if we can make this document more accessible: pdxscholar@pdx.edu. 


\section{THESIS APPROVAL}

The abstract and thesis of Shaun Andrew Marcott for the Master of Science in

Geology were presented August 11, 2005, and accepted by the thesis committee and the department.

COMMITTEE APPROVALS:

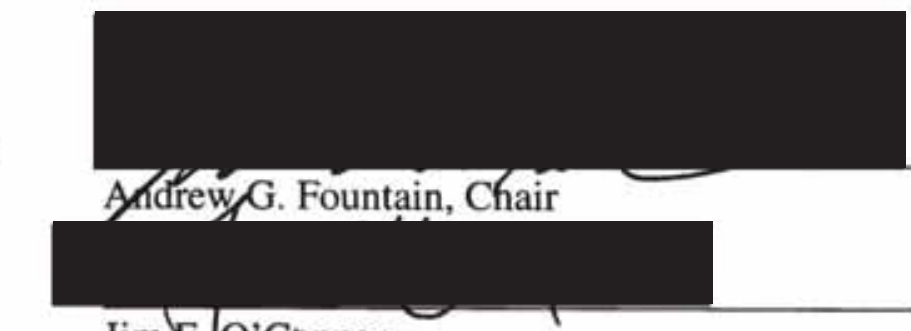

Jimkilo'Connor

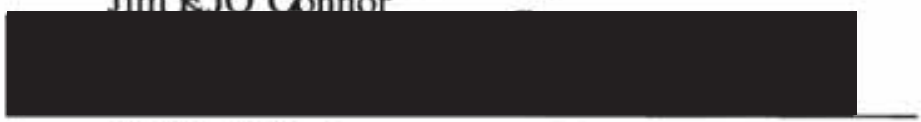

Scott F Burns

J. Aląh Yeakley

Representative of the Office of Graduate Studies

DEPARTMENT APPROVAL:

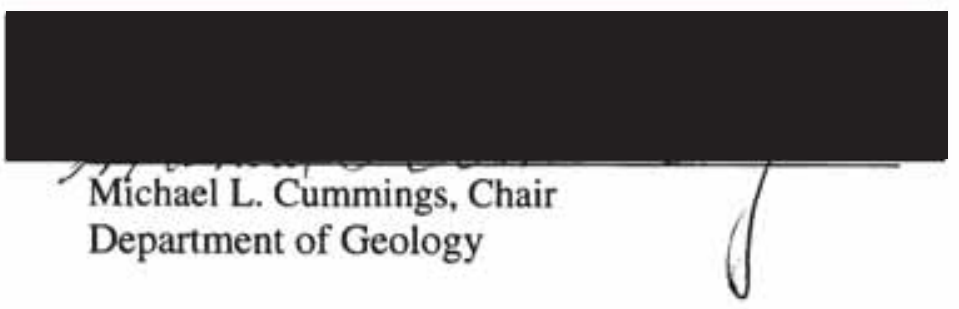




\begin{abstract}
An abstract of the thesis of Shaun Andrew Marcott for the Master of Science in Geology presented August 11, 2005.
\end{abstract}

Title: A Tale of Three Sisters: Reconstructing the Holocene glacial history and paleoclimate record at Three Sisters Volcanoes, Oregon, United States.

At least four glacial stands occurred since 6.5 ka B.P. based on moraines located on the eastern flanks of the Three Sisters Volcanoes and the northern flanks of Broken Top Mountain in the Central Oregon Cascades. The youngest of these advances was the Little Ice Age (LIA) glaciation, which reached its maximum advance $150-200$ yrs. B.P. and is defined by the large sharp crested and unvegetated moraines adjacent to the modern glaciers. In isolated locations less than $100 \mathrm{~m}$ downslope from these moraines, a second set of sparsely vegetated lateral moraines marks the Late-Neoglacial stand of the glaciers between $2.1 \pm 0.4$ and $7.7 \mathrm{ka}$ B.P. A third set of Early-Neoglacial end moraines is $300-700$ meters downslope of the modern glacier termini, and postdates 7.7 ka B.P. From SST temperature data (Barron et al., 2003) and a speleothem record (Vacco, 2003), we infer that this advance occurred between 4.5 and 6.5 ka B.P. Finally, the Fountonnor stand is marked by moraines 500-900 meters downslope of the modern glacier termini, and we infer these are latest Pleistocene or early Holocene. 
Modern equilibrium line altitudes (ELAs) at the Three Sisters and Broken Top are approximately $2500-2600 \mathrm{~m}$. During the LIA, the ELAs were $40-180 \mathrm{~m}$ lower, requiring cooler mean summer temperatures by $0.7-1.0^{\circ} \mathrm{C}$ and winter snowfall to increase by $10-60 \mathrm{~cm}$ water equivalent. The average Early-Neoglacial and Fountonnor ELAs were $130-300 \mathrm{~m}$ and $290-320 \mathrm{~m}$ lower than modern glaciers, respectively, requiring air temperatures to be $0.7-1.6^{\circ} \mathrm{C}$ and $1.5-1.7^{\circ} \mathrm{C}$ cooler during the summer and winter snowfall to be $40-100 \mathrm{~cm}$ water equivalent and $90-$ $100 \mathrm{~cm}$ water equivalent greater. 


\title{
'A TALE OF THREE SISTERS: RECONSTRUCTING THE HOLOCENE GLACIAL HISTORY AND PALEOCLIMATE RECORD AT THREE SISTERS VOLCANOES, OREGON, UNITED STATES.
}

by

SHAUN ANDREW MARCOTT

A thesis submitted in partial fulfillment of the requirements for the degree of

\author{
MASTER OF SCIENCE \\ in \\ GEOLOGY
}

Portland State University

2005 


\section{Acknowledgments}

I would like to express my gratitude to my boss and advisor, Andrew Fountain, for his support throughout this thesis and for protecting me from the glacier database project. Through our stimulating discussions on all varieties of subject matter, I feel that I have learned a great deal about life and science. Thank you. I would like to thank Jim O'Connor for his patience in answering my never-ending emails about the geology of Three Sisters and for all the insight he has given me during this project. Without his help, this project would have never left the ground. I would also like to thank my other committee members, Scott Burns and Alan Yeakley, for their insightful comments that helped improve this thesis.

Because no master's thesis that involves fieldwork is done alone, I would like to thank Matt Brunengo, Jon Ebnet, Ashleigh Fines, Matt Hoffman, Seth Moorehead, Peter Sniffen, and Andy Urich for helping lug all my gear up and down the mountains. Without your assistance, my back would surely be broken and very little fieldwork could have been accomplished. I would also like to thank Dr. Doug Clark and Niki Bowerman of Western Washington University for taking five days out of their busy schedules to help collect the lake cores during the spring of 2005. They, as well as all my field partners, embody the altruistic character that is becoming rare in science today. I am forever grateful to you all.

Thanks to Willie Scott for sharing all of his knowledge about the glacial history of Oregon. Without his comments and suggestions, this thesis would have taken much longer and would have suffered many setbacks. Thanks to David Dethier 
for providing his unpublished field maps of Broken Top and South Sister. They proved most useful and made a large impact on the thesis. Thanks to Peter Sniffen for reading every draft, abstract, grant, field note, and any other piece of paper related to this project. Your friendship has kept me going through this project, and I thank you for your personal support. And most importantly, I would like to thank my wife, Lennie. Your support throughout this project and master's degree have kept me going when, at times, I wanted to stop. I appreciate every sacrifice you have made for us, and I thank you for your patience and willingness to help me continue down the road of science.

Support for this project has come from the following sources: Scott Burns and Michael Cummings have provided support for all the radiocarbon dating, the Portland State Geology Department provided funding to support field expenses through the Howell and Rockie Memorial Scholarship, and both the Mazamas Mountaineering Club and the Geological Society of America have provided funding for future work on this project during the summer of 2005. 


\section{Table of Contents}

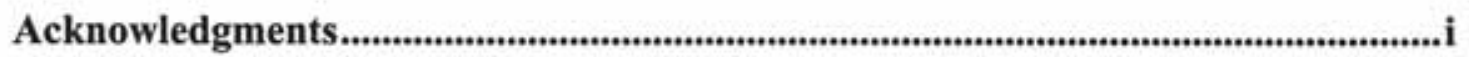

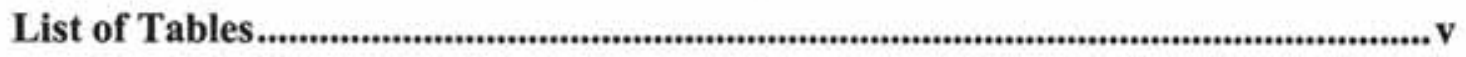

List of Figures ..................................................................................................................vi

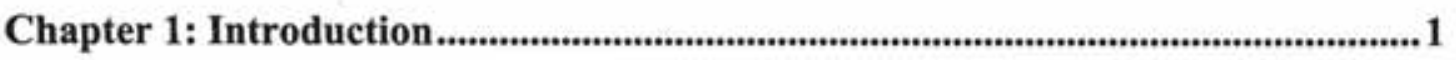

1.1 Timing of late Pleistocene and early Holocene glacial advances in the western

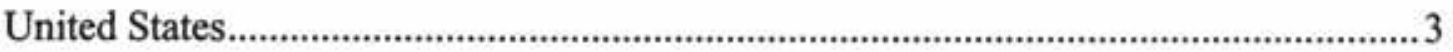

1.2 Field Site

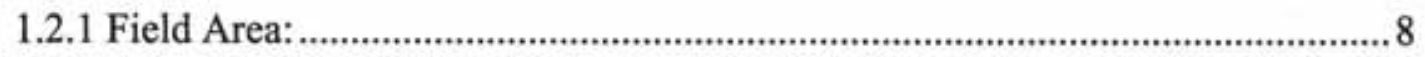

1.2.2 Geologic Setting of Three Sisters Volcanoes:...................................................12

Chapter 2: Glacial Deposits and Stratigraphic Sections.............................................15

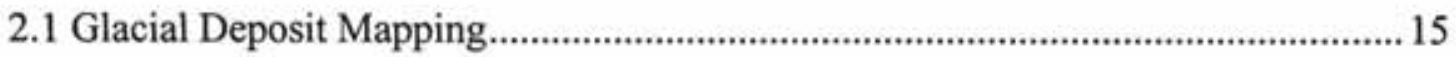

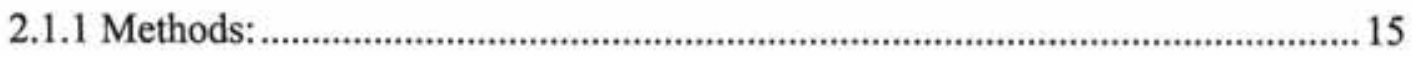

2.1.2 Results: Moraine Deposits: ......................................................................

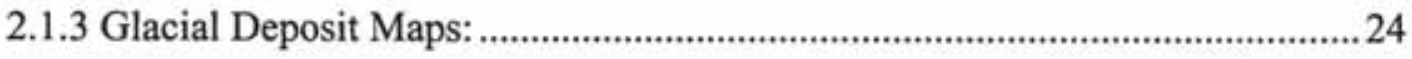

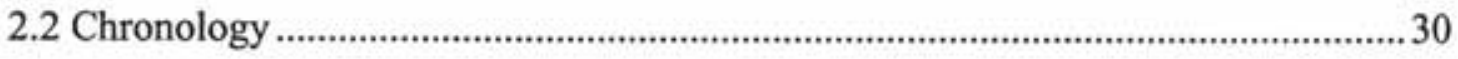

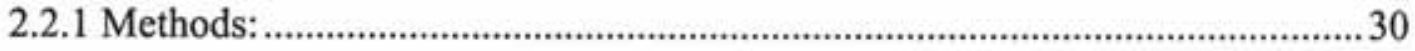


2.2.2 Auger Pit and River Exposure Stratigraphy:....................................................34

2.2.3 Lake Core Stratigraphy: ..................................................................................40

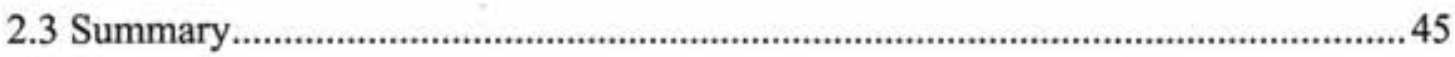

Chapter 3: Equilibrium Line and Paleoclimate Reconstructions...........................49

Chapter 4: Discussion and Conclusions ..................................................................64

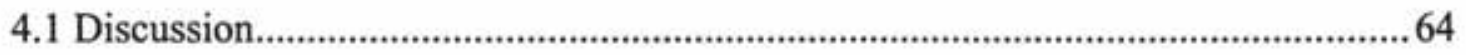

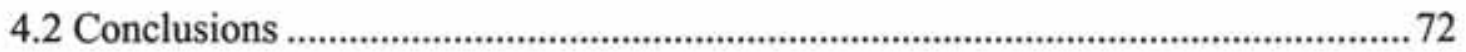

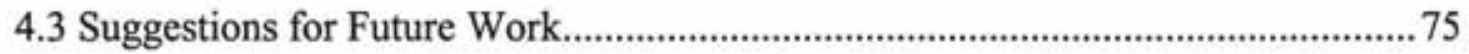

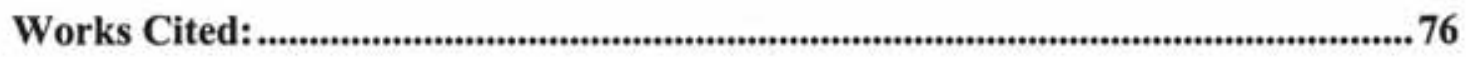

Appendix: Detailed Stratigraphic Sections ...............................................................86 


\section{List of Tables}

Table 1: Summary of glacial advances in western North America. LGM is the Last Glacial Maximum; $\mathrm{H} 1$ is the Heinrich 1 event; YD is the Younger Dryas; and

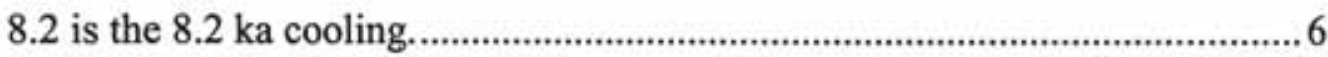

Table 2: Moraine characteristics on the eastern slopes of the Three Sisters and the northern slope of Broken Top mountain. DHRM is Devil's Hill / Rock Mesa tephra. MZ is Mazama tephra......................................................................... 16

Table 3: Equilibrium line altitudes (BR method) for the glaciers at Three Sisters and Broken Top during the modern, Little Ice Age, Early-Neoglacial, and Fountonnor glacial periods. 54

Table 4: Equilibrium line altitudes (AAR method) for the glaciers at Three Sisters and Broken Top during the modern, Little Ice Age, Early-Neoglacial, and

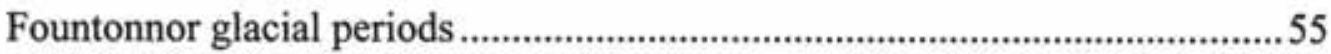

Table 5: Meteorological stations used to calculate linear regression line for mean summer temperature (1971-2001) (WRCC, 2005). 58

Table 6: Meteorological stations used to calculate linear regression line for mean winter accumulation (1971-2000) (NRCS, 2005). .59

Table 7: Estimated modern climate conditions at present and past glacier equilibrium lines (balance ratio). 60 


\section{List of Figures}

Figure 1: Distribution of recent research on dated glacial maxima in the western United States. The dotted oval represents a geographical hole in glacial database. Numbers at each specific location are dates of glacial extents and are measured in thousands of years before present. .................................................

Figure 2: Comparison of glacial advances in the western United States with inferred global air temperatures based on the oxygen isotope curve from the Greenland Ice Sheet Project 2 (GISP2) ice core (Stuiver and Grootes, 2000) and the deuterium curve from the Lake Vostok ice core from Antarctica (Lorius et al., 1985; Sowers et al., 1993). The darkened bars represent global cooling events from the GISP2s ice core (LGM = Last Glacial Maximum, H1 = Heinrich 1 event, $\mathrm{YD}=$ Younger Dryas, and $8.2=8.2 \mathrm{ka}$ cooling event)........................... 5

Figure 3: Location map of Three Sisters volcanic center and Broken Top mountain.

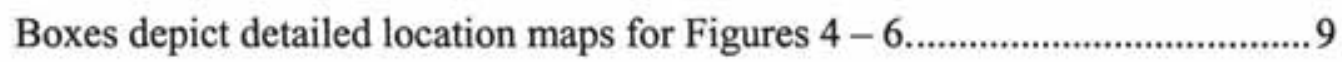

Figure 4: Digital elevation map with $100 \mathrm{~m}$ contours displaying present glaciers, snowfields and notable topographic features at North and Middle Sister, Oregon Cascades. 10

Figure 5: Digital elevation map with $100 \mathrm{~m}$ contours displaying present glaciers, snowfields and notable topographic features at South Sister, Oregon Cascades. 
Figure 6: Digital elevation map with $100 \mathrm{~m}$ contours displaying present glaciers, snowfields and notable topographic features at Broken Top mountain located approximately $3 \mathrm{~km}$ east of South Sister

Figure 7: Aerial photograph of North Sister. The black lines outline the area of the photograph from Figure 8. The camera symbol indicates the location of the picture and the arrows depict moraines crests downslope of Linn glacier........17

Figure 8: Northeast flank of North Sister with LIA moraines from Linn glacier. For scale, the moraines are approximately $60 \mathrm{~m}$ in height. Arrows depict the moraine crests. Picture in upper right-hand corner is a close-up of a LIA moraine. Andy Urich in foreground. 18

Figure 9: Aerial photograph between Middle and South Sister. The black lines outline the area of the photograph from Figure 10. The camera symbol indicates the location of the picture and the dashed lines depict moraines crests. 19

Figure 10: Camp Lake between South and Middle Sisters with LIA, Late-Neoglacial, and Fountonnor moraines extending down the slopes from Carver glacier. Notice differences in vegetation cover and moraine positions. Also, notice that Early-Neoglacial moraines are absent in this moraine set. For scale, the LIA moraines are $60 \mathrm{~m}$ high and the Fountonnor moraines are $\sim 5 \mathrm{~m}$. Picture in upper right-hand corner is a close-up of a Late-Neoglacial moraine. 20

Figure 11: Aerial photograph for Middle Sister. The black lines outline the area of the photograph from Figure 12 and 13. The camera symbol indicates the location of the picture and the dashed lines depict moraines crests. 
Figure 12: East flank of Middle Sister displaying an Early-Neoglacial end moraine. Notice vegetation cover on moraine flanks and crest. For scale, the moraine is approximately $30 \mathrm{~m}$ high. Pictures in upper right-hand corner are close-ups of an Early-Neoglacial moraine. 22

Figure 13: East flank of Middle Sister with LIA, Fountonnor, and pre-Fountonnor moraines extending down the slopes from Diller Glacier. Notice the difference in vegetation cover and deflated moraine heights between the three moraine sets. For scale, the LIA moraines are $60 \mathrm{~m}$ high while the Fountonnor moraine is $\sim 20 \mathrm{~m}$. Picture in upper right-hand corner is a close-up of a Fountonnor moraine.

Figure 14: Geomorphologic map of glacial deposits and timing of glacial advances/stands for the Three Sisters and Broken Top mountain. .25

Figure 15: Geomorphologic map of South Sister including current glaciers and snowfields, glacial deposits, and moraine crests on the south, east, and north flanks. Contour interval is $50 \mathrm{~m}$. .26

Figure 16: Geomorphologic map of Middle Sister including current glaciers and snowfields, glacial deposits, and moraine crests on the south and east flanks. Contour interval is $50 \mathrm{~m}$. 27

Figure 17: Geomorphologic map of North Sister including current glaciers and snowfields, glacial deposits, and moraine crests on the east and north flanks. Contour interval is $50 \mathrm{~m}$. 28 
Figure 18: Geomorphologic map of Broken Top including current glaciers and snowfields, glacial deposits, and moraine crests on the north and south flanks. Contour interval is $50 \mathrm{~m}$. 29

Figure 19: Schematic of two scenarios of a simplified depositional environment associated with two moraine-dammed lakes \{adapted from (Heine, 1997)\}. In the left scenario, lake sediments that are directly upslope of the moraines are at or near the surface. Lake sediment collected behind moraines B and C are easily obtained and a minimum date of the moraine's deposition can be established. Lake sediments upslope of moraine $\mathrm{C}$ can also give bracketing dates of moraine B's deposition, assuming the glacial outwash associated with moraine B can be penetrated. In the right scenario, outwash and morainal material directly upslope of the moraines is at or near the surface. In this situation, lake sediment samples collected behind both moraine B and C cannot be obtained because outwash from the upslope moraines is typically too coarse to penetrate. 31

Figure 20: Lake coring photographs from Camp Lake during April of 2005. Doug Clark and Niki Bowerman of Western Washington University shown operating

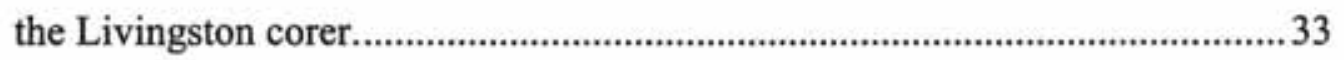

Figure 21: Stratigraphic columns from six auger cores recorded near South and Middle Sisters. No organic rich lake deposits were found in these cores. Detailed stratigraphic sections of these cores are in Appendix. .35 
Figure 22: Stratigraphic columns from two auger cores (Sites $16 \& 43$ ) and river exposures (Sites 05 \& 15) recorded near Middle Sister and Broken Top Mountain. The only organic rich lake sediments were found at Site 43 . Detailed stratigraphic sections of these cores are in Appendix. 37

Figure 23: Photograph of Fountonnor till directly overlain with Mazama tephra (arrow). 39

Figure 24: Geomorphologic map of glacial deposits and moraine crests near Camp and Chamber Lakes between Middle and South Sisters. The black dot is where the sediment core for Camp Lake was collected. Contour interval is $50 \mathrm{~m}$. 41

Figure 25: Diagram of Camp Lake core with magnetic susceptibility and generalized particle sizes. 42

Figure 26: Photo of alternating colors in lake muds in upper section of core (33-41 $\mathrm{cm})$. 43

Figure 27: Photo of Collier Cone tephra deposit underlying lake muds $(45-50 \mathrm{~cm}) \ldots 43$

Figure 28: Photos of Devil's Hill / Rock Mesa rhyolitic tephra. Photo A is of the first $10 \mathrm{~cm}$ of the tephra and photo B (with the red sinters) is part of the lower section of the tephra $(75-82 \mathrm{~cm})$.

Figure 29: Oxidized lower mud layer with basalt pebble $(118-128 \mathrm{~cm})$. Notice rusty color of the mud layer. .44

Figure 30: Shape profile used to calculate the area for modern, Little Ice Age, and Early-Neoglacial at Diller and Hayden glaciers (top), Prouty glacier (middle), and Bend glacier (bottom). 52 
Figure 31: Shape profile used to calculate the area for modern and Little Ice Age at Lewis glacier (top) and Linn glacier (bottom). .53

Figure 32: Winter accumulation versus mean summer temperature (June - August) at the equilibrium lines of 32 glaciers with worldwide distribution (Leonard, 1989) 56

Figure 33: Linear regression line for mean summer temperature $\left({ }^{\circ} \mathrm{C}\right)$ versus elevation (m) for six meteorological stations near the Three Sisters Volcanoes. .57

Figure 34: Linear regression line for highest monthly mean winter accumulation $(\mathrm{cm}$ weq.) versus elevation (m) for four meteorological stations east of the Three Sisters Volcanoes. .59

Figure 35: Estimated modern climates at present, LIA, Early-Neoglacial and Fountonnor glacier equilibrium lines (adapted from Leonard, 1989). Black lines are climate envelope defined by Kotlyakov and Krenke (1982) and illustrated in Leonard (1989). 61

Figure 36: Winter accumulation versus mean summer temperature at the equilibrium lines of glaciers throughout the world (Leonard, 1989). Arrows and numbers indicate minimum and maximum summer temperature depressions and winter accumulation increases needed to shift the paleo-ELAs into modern glacier conditions 62

Figure 37: Reconstructed temperature and precipitation data from tree ring-widths and latewood density chronologies for the Pacific Northwest (1760-1980). Bold lines are 7-year moving average of temperature and precipitation data. The 
upper graph is the reconstructed mean temperature $\left({ }^{\circ} \mathrm{C}\right)$ from April to September (Wiles et al., 1996). The lower graph is the reconstructed annual precipitation $(\mathrm{mm})$ for several sites near $43^{\circ} 40^{\prime} \mathrm{N}, 119^{\circ} 48^{\prime} \mathrm{W}$ in Eastern

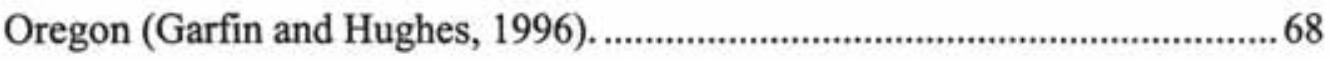

Figure 38: Reconstructed oxygen isotope curve from the GISP2 Ice Core record (top) (Stuiver and Grootes, 2000) and the reconstructed sea surface temperature (SST) from alkenones at Site 1019 in the Pacific Ocean just off the northern coast of California and southern coast of Oregon (bottom) (Barron et al., 2003)

Figure 39: Oxygen-18 record from a stalagmite record (OCNM8-02A) collected from Oregon Caves National Monument in southwestern Oregon (Vacco, 2003). The bold line represents a 10-point running mean of the oxygen-18 data. It is apparent that a large cooling event took place during the Younger Dryas time intervals $(13.0-12.0$ ka B.P.) followed by a brief warming $(12.0-10.8 \mathrm{ka}$ B.P.) and cooling (10.8 -10.0 ka B.P. $)$ event. 71

Figure 40: Comparison of glacial advances and stands in the Three Sisters Wilderness with inferred global air temperatures based on the oxygen isotope curve from the Greenland Ice Sheet Project 2 (GISP2) ice core (Stuiver and Grootes, 2000) and the deuterium curve from the Lake Vostok ice core from Antarctica (Lorius et al., 1985; Sowers et al., 1993) 71

Figure 41: Detailed stratigraphic section of river exposure along the North Fork of Squaw Creek (Site 05) .86 
Figure 42: Detailed stratigraphic section of auger pit near Camp Lake between South and Middle Sisters (Site 16). Radiocarbon dates of $230 \pm 10 \mathrm{yrs} \mathrm{B.P.} \mathrm{and} 80 \pm$ 60 yrs. B.P. correspond to Beta numbers 203136 and 200871 , respectively... 87

Figure 43: Detailed stratigraphic section of auger pit downslope of Carver Lake on South Sister (Site 18). 88

Figure 44: Detailed stratigraphic section of auger pit near Green Lake between South Sister and Broken Top Mountain (Site 20). 89

Figure 45: Detailed stratigraphic section of auger pit downslope of Prouty Glacier on South Sister (Site 24). 89

Figure 46: Detailed stratigraphic section of auger pit on saddle north of Green Lake (Site 27). .90

Figure 47: Detailed stratigraphic section of auger pit upslope of an apparent preFountonnor moraine on Middle Sister (Site 32). Radiocarbon dates of $<50 \mathrm{yrs}$ B.P. corresponds to Beta numbers 200872. 90

Figure 48: Detailed stratigraphic section of soil pit dug overlying a Fountonnor till or outwash deposit downslope of Broken Top (Site 41). 91

Figure 49: Detailed stratigraphic section of auger pit downslope of Bend Glacier on Broken Top (Site 43). Radiocarbon dates of $875 \pm 85$ yrs. B.P. and $<50$ yrs. B.P. correspond to Beta numbers 200873 and 203137, respectively. 92 


\section{Chapter 1: Introduction}

Small mountain glaciers respond sensitively to climate (Lowe and Walker, 1997; Owen et al., 2003), thus determining the timing and extent of past glaciation can lead to inferences of past climate. Recent research on glacial activity during the last deglaciation has identified several late Pleistocene and early Holocene glacial advances in Washington, Idaho, Montana, California, and northeastern Oregon (Clark, 1997; Clark and Gillespie, 1997; Heine, 1997; Licciardi et al., 2004; Owen et al., 2003; Phillips et al., 1996; Porter and Swanson, 1998; Thackray et al., 2004) (Figure 1). These advances occured at $17 \mathrm{ka}, 14 \mathrm{ka}$, and $10 \mathrm{ka}$ before present (B.P.) and are peculiar because of their timing relative to dated advances elsewhere. The glacial advance at 17 ka B.P. was 4,000 years after the "accepted" Last Glacial Maximum (LGM) at $21 \pm 2$ ka B.P. (Licciardi et al., 2004) and was followed by two smaller advances at $14 \mathrm{ka}$ and $10 \mathrm{ka}$ B.P. that apparently culminated before and just after the well-documented Younger Dryas world-cooling event at $12.9 \mathrm{ka}-11.6 \mathrm{ka}$ B.P. These advances may be associated with reinvigorated precipitation activity, resulting from increased advection from the Pacific Ocean as the ice sheet retreated north (Thackray et al., 2004) and/or with global cooling triggered by the disruption of the marine thermohaline circulation in the ocean caused by a large discharge of fresh water into the North Atlantic (Heinrich events) (Clark and Bartlein, 1995; Hostetler et al., 2000; Licciardi et al., 2004). 


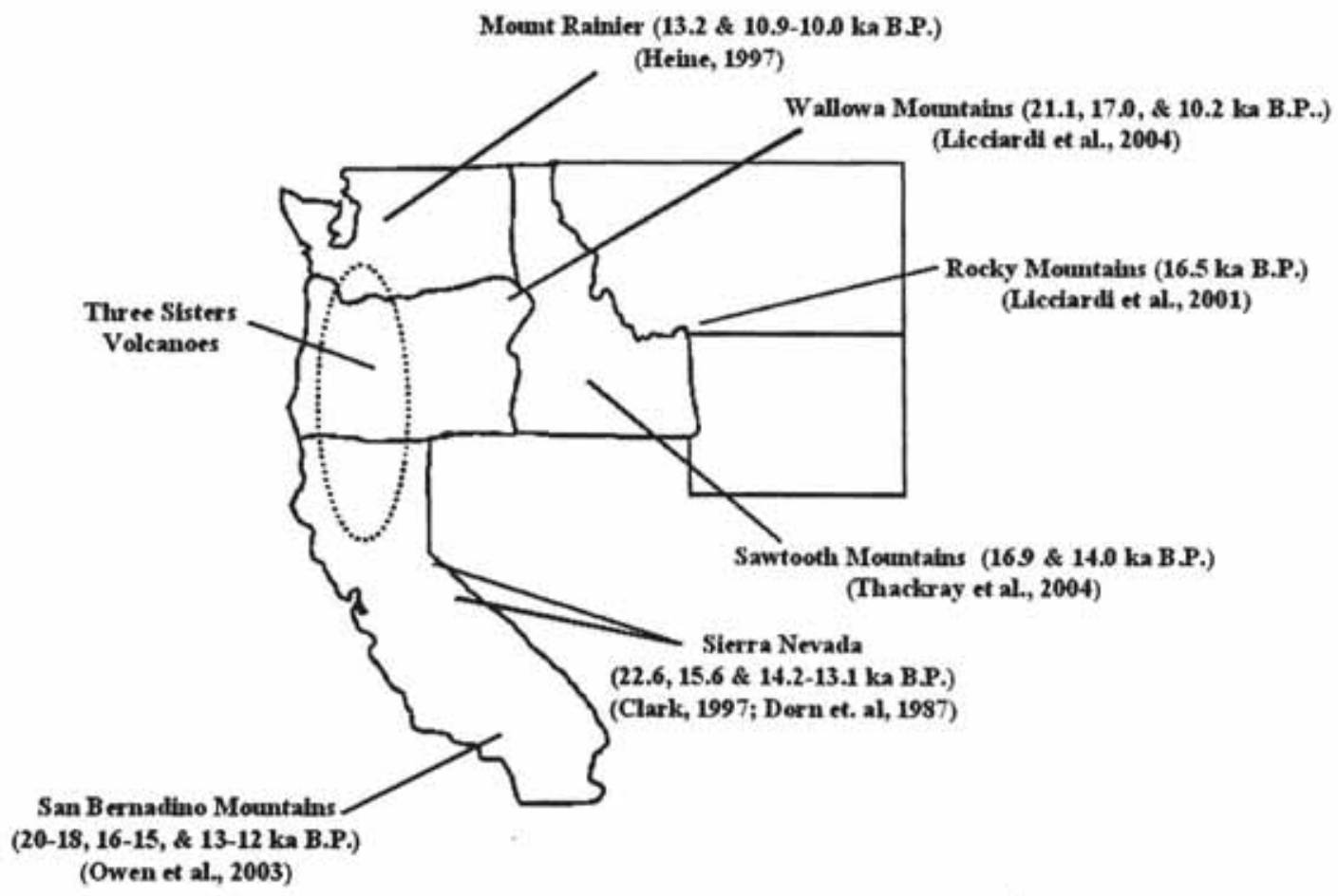

Figure 1: Distribution of recent research on dated glacial maxima in the western United States. The dotted oval represents a geographical hole in glacial database. Numbers at each specific location are dates of glacial extents and are measured in thousands of years before present.

Despite extensive research in the western United States, particularly in the North Cascades and the Sierra Nevada, the glacial record has been studied very little in the Oregon Cascades. Defining the timing and extent of past glacier change in Oregon will help assess if the late Pleistocene to Holocene glaciations were synchronous or varied throughout the western United States. This information can then be used to define the regional pattern of climate change of western North America during the last $\sim 17,000$ years.

The Three Sisters volcanoes, including Broken Top mountain, of Central Oregon contain numerous well-preserved lateral and end moraines on their eastern slopes and are considered to be Pleistocene and Holocene in age (Dethier, 1980a, b; 
O'Connor et al., 2001; Scott and Gardner, 1992; Scott et al., 1990; Sherrod et al., in press). Access to the eastern side of the mountains and the sparse vegetation cover, relative to the western flanks, makes the area an ideal field site for mapping the glacial features. The work at Three Sisters will contribute to our understanding of the glacial record in the western U.S., particularly at the Pleistocene/Holocene boundary, and will assist in our understanding of both regional and paleoclimate patterns and perhaps global paleoclimate systems.

The goals of this thesis are three fold: to map in detail the glacial deposits at Three Sisters, which will help determine the magnitude of past glacial extents, to date the glacial deposits and place their timing in the context of other advances in the western United States, and to infer past climatic conditions required for the past extents. I will attempt to show that four glacial advances and/or stands occurred at Three Sisters and that some correlate with other advances in the Pacific Northwest while others do not.

\subsection{Timing of late Pleistocene and early Holocene glacial advances in the western United States}

For consistency, all age dates listed in this thesis are reported in calibrated years before present, whenever possible. If radiocarbon dates from other journals or

reports were given in radiocarbon year $\left({ }^{14} \mathrm{C}\right)$, they were calibrated to years before present with the CALIB program (Stuiver and Reimer, 1993) using the $2 \sigma$ confidence interval. These dates are listed with both the calibrated years before present (B.P.) and 
the radiocarbon dates $\left({ }^{14} \mathrm{C}\right)$ \{i.e. 21.5 ka B.P. $\left(18{ }^{14} \mathrm{C}\right.$ ka B.P. $\left.)\right\}$. Surface exposure dates, such as ${ }^{10} \mathrm{Be}$ and ${ }^{36} \mathrm{Cl}$, are listed in the text as cosmogenic years before present (i.e. $22.2 \mathrm{ka}^{36} \mathrm{Cl}$ ) but are assumed to be equivalent to calibrated years before present (B.P.).

Previous work of glacial advances in the western U.S. shows that alpine glaciers advanced during five or six different time intervals between the late Pleistocene ( 25 ka B.P.) and early Holocene ( 8 ka B.P.) (Figure 2). The largest and oldest advance considered in this analysis is the last glacial maximum (LGM) at approximately $19 \pm 1$ ka B.P., based on ${ }^{10} \mathrm{Be}$ and ${ }^{36} \mathrm{Cl}$ radiometric dates, collected from boulders of lateral and end moraines in California and Washington (Table 1) (Owen et al., 2003; Phillips et al., 1996; Porter, 2004). Two dates differ from the $19 \pm$ 1 ka B.P. date, one from organic matter removed from rock varnishes of several moraine boulders at Pine Creek in the eastern Sierra Nevada (22.6 \pm 1.1 ka B.P.) $\left(19,050 \pm 420{ }^{14} \mathrm{C}\right.$ yrs B.P.) (Dorn et al., 1987) and the other from surface exposure dates from moraine boulders taken elsewhere in the Sierras $\left(25 \pm 1 \mathrm{ka}{ }^{36} \mathrm{Cl}\right)$ (Phillips et al., 1996). 


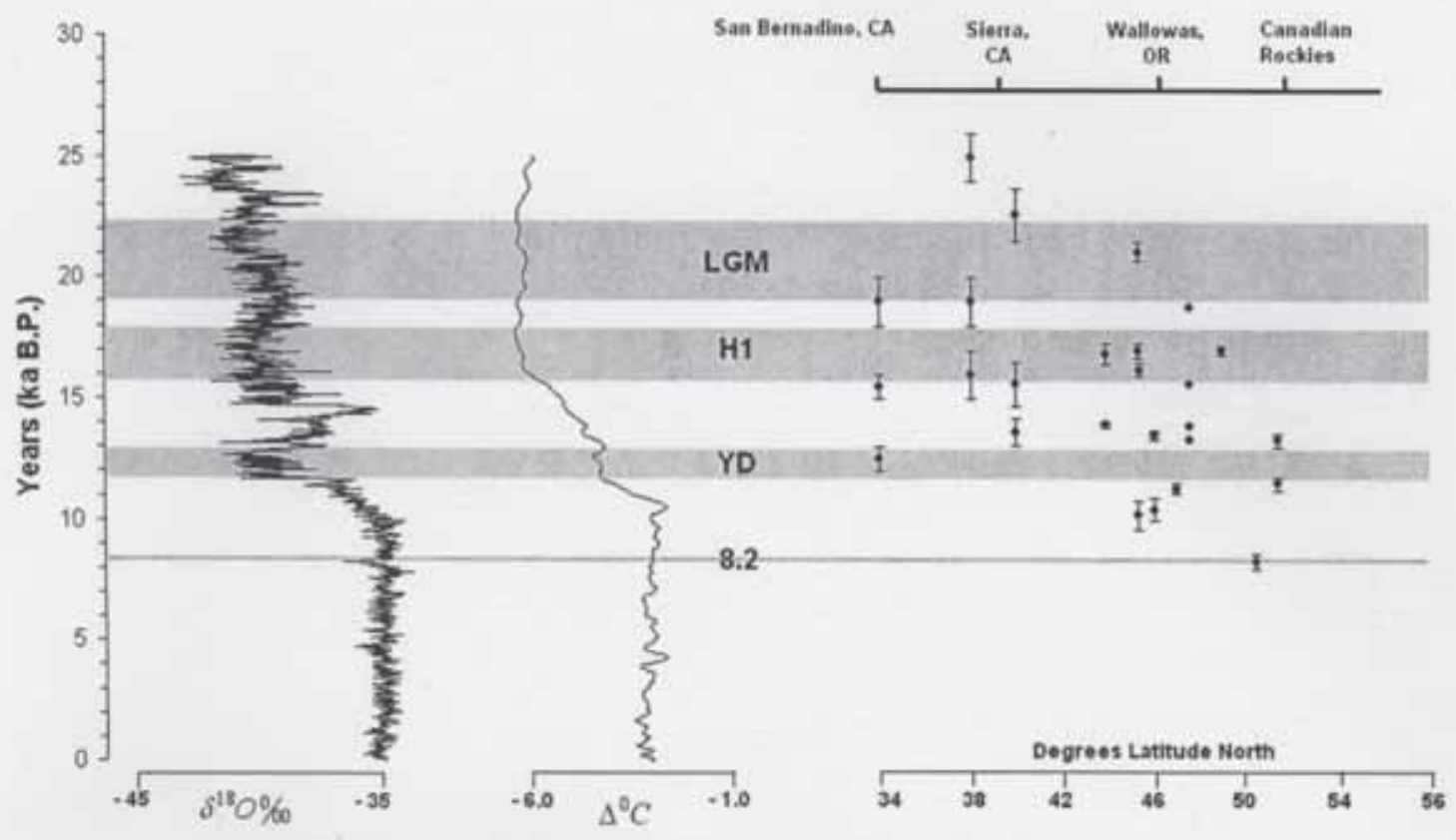

Figure 2: Comparison of glacial advances in the western United States with inferred global air temperatures based on the oxygen isotope curve from the Greenland Ice Sheet Project 2 (GISP2) ice core (Stuiver and Grootes, 2000) and the deuterium curve from the Lake Vostok ice core from Antarctica (Lorius et al., 1985; Sowers et al., 1993). The darkened bars represent global cooling events from the GISP2s ice core (LGM = Last Glacial Maximum, H1 = Heinrich 1 event, YD = Younger Dryas, and $8.2=8.2$ ka cooling event). 


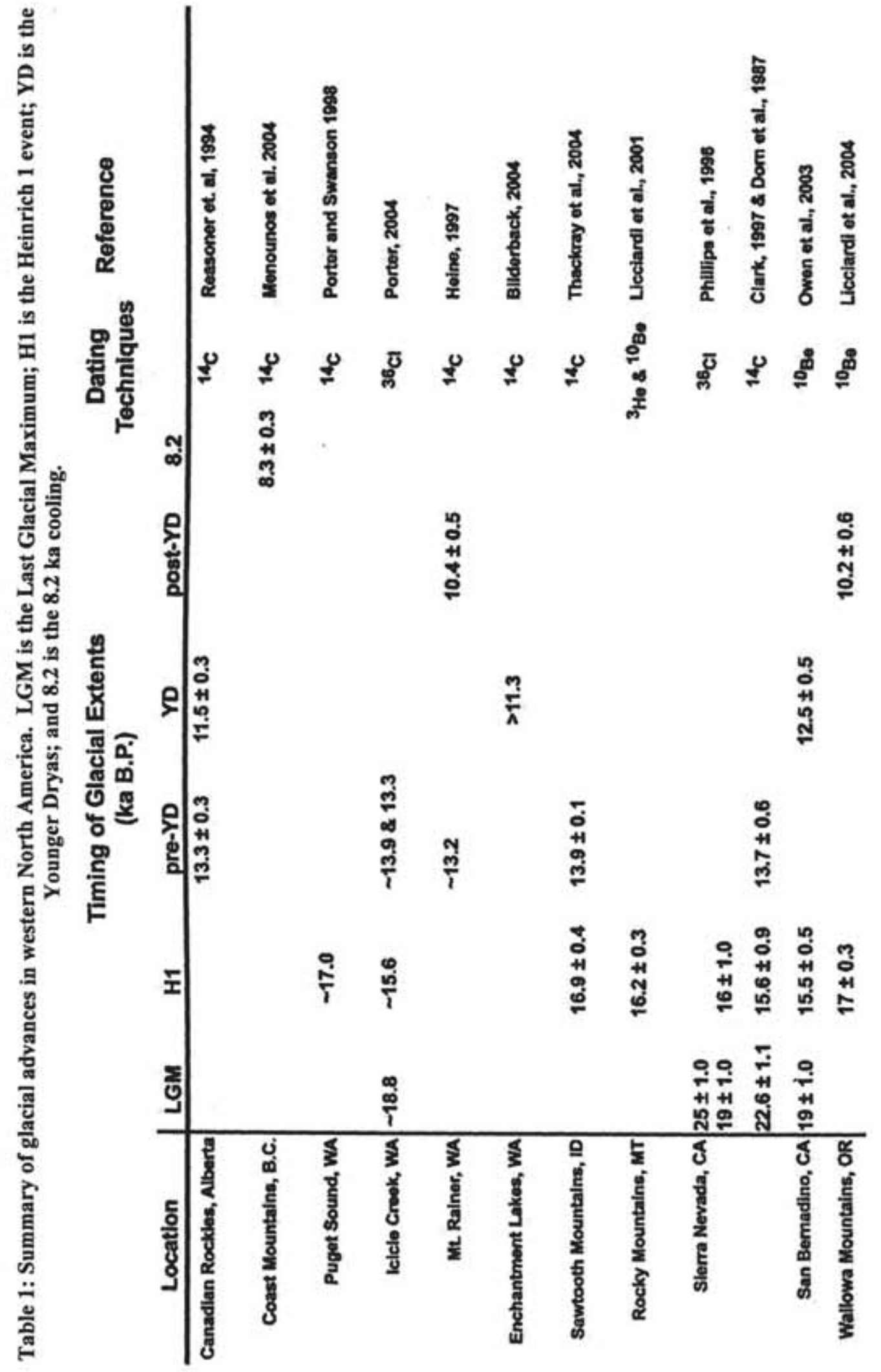


A second alpine advance followed 3,500 years later during the break up of the Laurentide Ice Sheet in the North Atlantic. This second advance, at $\sim 16.5 \pm 1$ ka B.P., has been linked to global cooling associated with the Heinrich I event ( 17 ka B.P.) in the North Atlantic that weakened thermohaline circulation in the world's oceans (Clark and Bartlein, 1995; Licciardi et al., 2004). Porter and Swanson (1998) and Thackray et al. (2004) suggested that reinvigorated moisture transport from the Pacific Ocean that was previously weakened by the Cordilleran and Laurentide ice sheets could have also caused this advance. Evidence of the Heinrich I advance has come from lake cores and cosmogenic dates from moraine boulders collected in Washington, Oregon, Montana, and California (Table 1) (Dorn et al., 1987; Licciardi et al., 2004; Licciardi et al., 2001; Owen et al., 2003; Phillips et al., 1996; Porter, 2004; Thackray et al., 2004).

The next three glacial advances occurred at the end of the Pleistocene or early Holocene. Lake cores and cosmogenic dates from Canada, Washington, Idaho, and California (Clark, 1997; Clark and Gillespie, 1997; Porter, 2004; Stuiver and Reimer, 1993; Thackray et al., 2004) stand as lines of evidence of the pre-YD advances, while a lake core in Washington (Heine, 1997) and cosmogenic dates from Oregon (Licciardi et al., 2004) infer a post-YD advance of the alpine glaciers (Table 1). However, despite the majority of the advances occurring pre- or post- YD, other advances in Canada, Washington, and California (Bilderback, 2004; Owen et al., 2003; Stuiver and Reimer, 1993) suggest a YD advance (Table 1), thus implying synchroneity with glacial advances recorded in Europe (Berglund, 1979; Larsen et al., 
1984; Mangerud, 1987) and Greenland (Stuiver and Grootes, 2000). The final advance during the early Holocene occurred near 8,200 years B.P. and was recorded in the Coast Mountains of British Columbia (Menounos et al., 2004). Whether this advance is exclusive to this single locality in Canada or appears elsewhere in western North America still remains to be tested.

\subsection{Field Site}

\subsubsection{Field Area:}

The Three Sisters mountains are composite lava cones located in the Southern Cascades of central Oregon $\left(44^{\circ} 08^{\prime} \mathrm{N}, 121^{\circ} 47^{\prime} \mathrm{W}\right)$ (Figure 3 - Figure 6). With a maximum elevation of nearly $3150 \mathrm{~m}$, six major glaciers (Collier, Diller, Hayden, Lost Creek, Prouty, and Renfew) currently survive on the mountains. These glaciers cover an area of $4.5 \mathrm{~km}^{2}$ with a total volume of $0.09 \mathrm{~km}^{3}$ (Driedger and Kennard, 1986). Separation and White Branch creeks drain the majority of the glaciers on the west side (e.g. Collier, Lost Creek, and Renfew) into the McKenzie River. Glaciers on the eastern side (e.g. Diller, Hayden, and Prouty) drain to Squaw and Fall creeks, empty into Sparks Lake, and, eventually, run into the Deschutes River (Driedger and Kennard, 1986). 


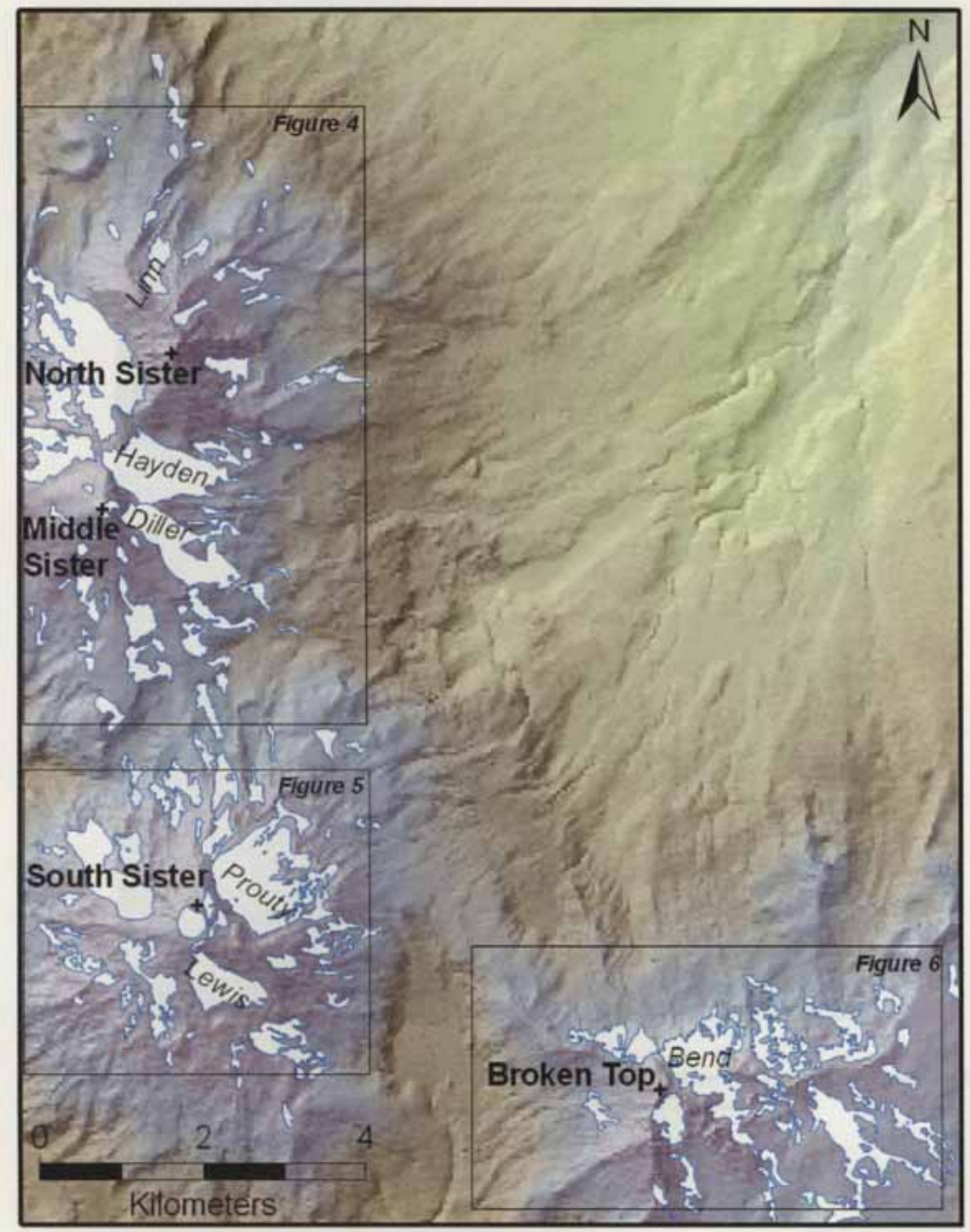

Figure 3: Location map of Three Sisters volcanic center and Broken Top mountain. Boxes depict detailed location maps for Figures 4-6. 


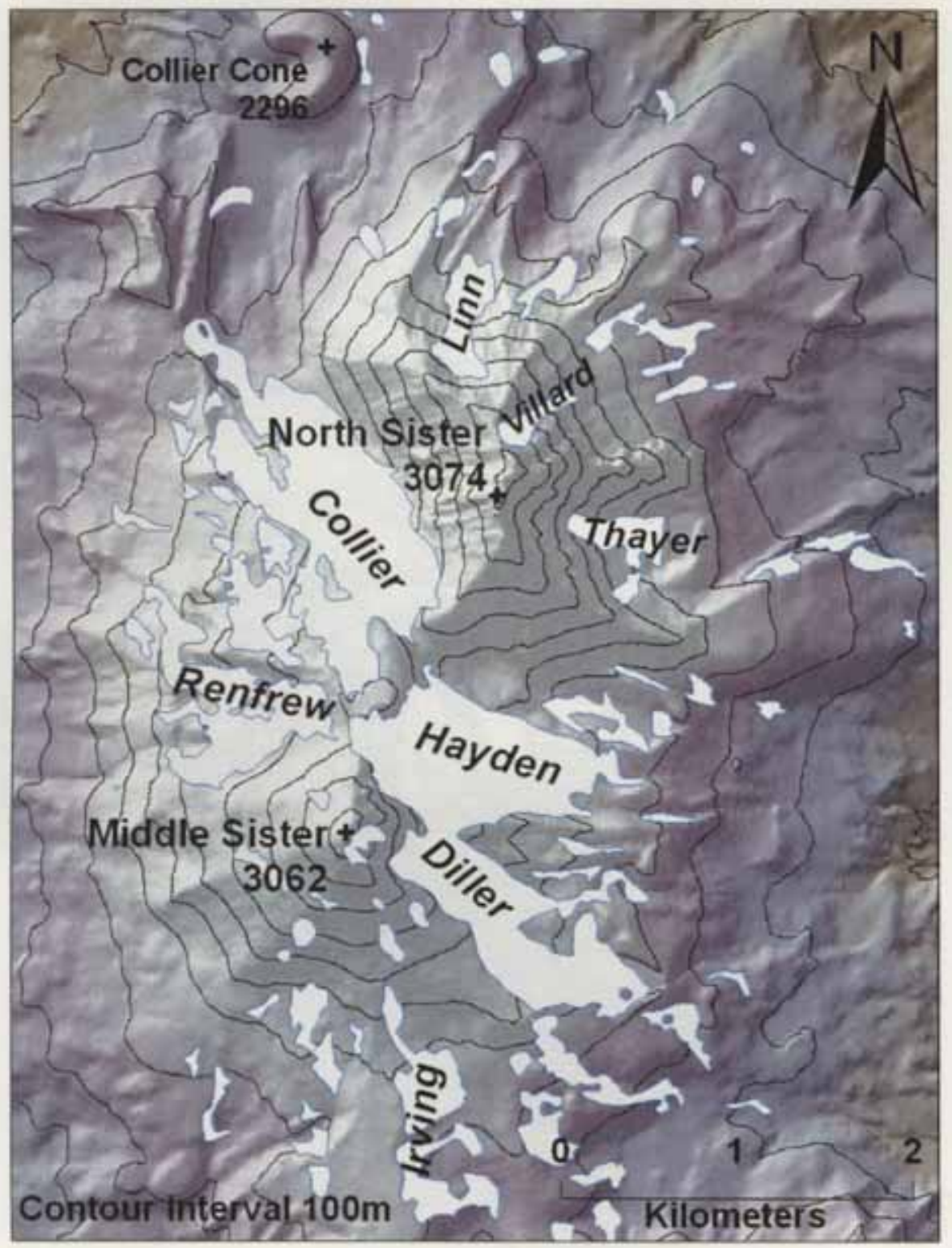

Figure 4: Digital elevation map with $100 \mathrm{~m}$ contours displaying present glaciers, snowfields and notable topographic features at North and Middle Sister, Oregon Cascades. 


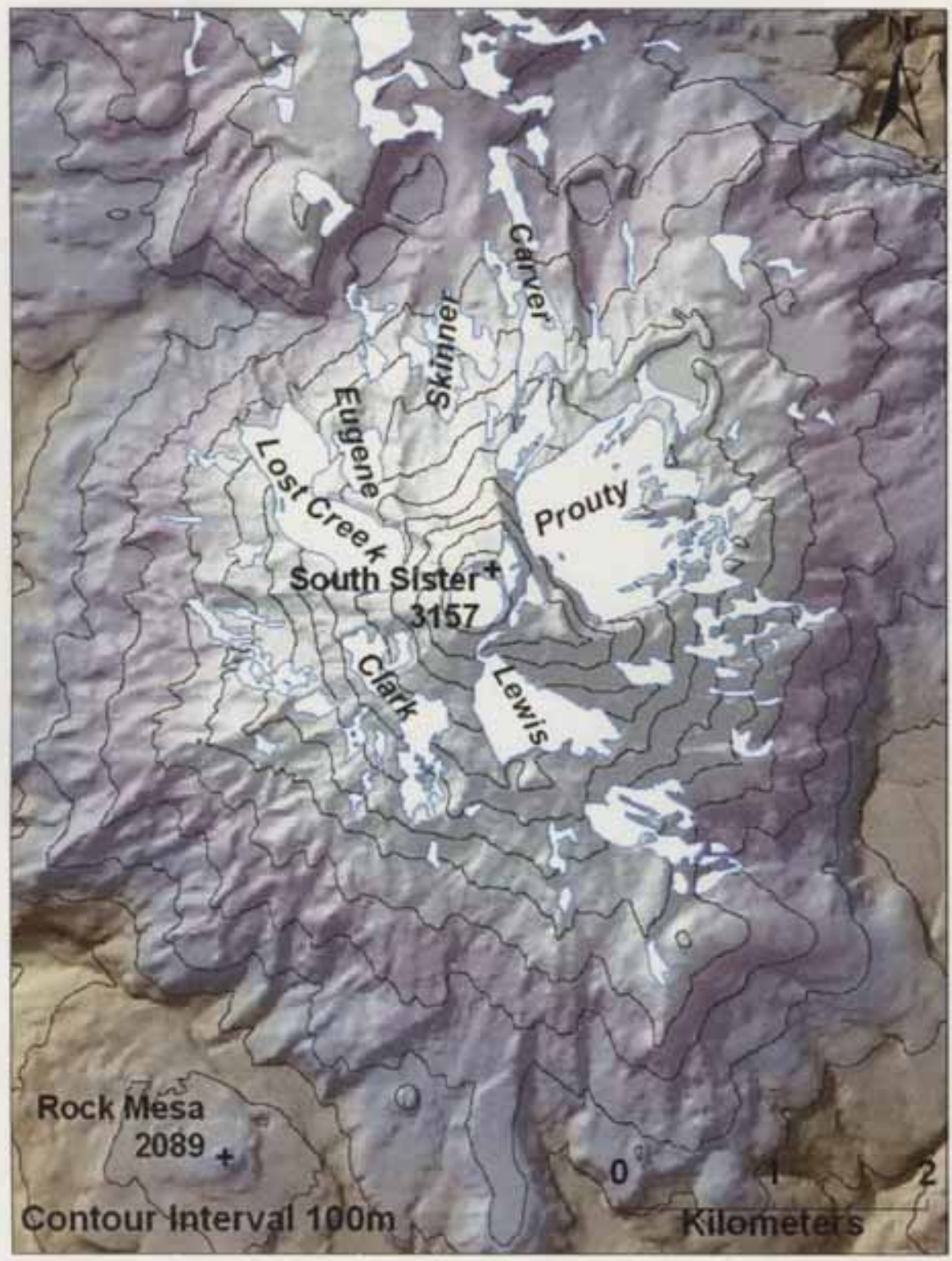

Figure 5: Digital elevation map with $100 \mathrm{~m}$ contours displaying present glaciers, snowfields and notable topographic features at South Sister, Oregon Cascades. 


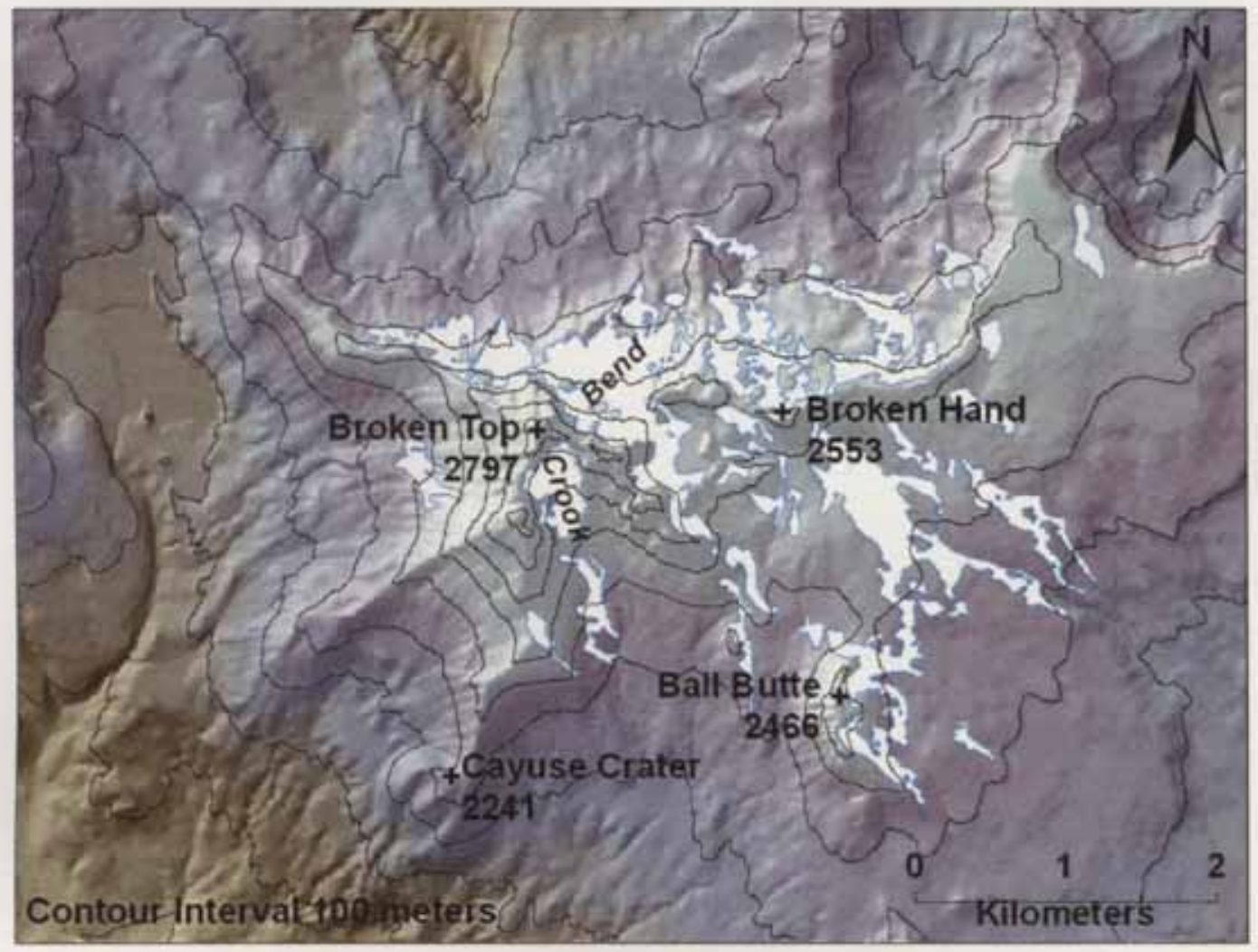

Figure 6: Digital elevation map with $100 \mathrm{~m}$ contours displaying present glaciers, snowfields and notable topographic features at Broken Top mountain located approximately $\mathbf{3} \mathrm{km}$ east of South Sister.

\subsubsection{Geologic Setting of Three Sisters Volcanoes:}

The age of the Three Sisters volcanic center is not well constrained, but its formation is thought to be restricted to the Pleistocene (Scott and Gardner, 1992). North Sister is the oldest volcano of the Three Sisters and is a basaltic-andesite lava cone overlying an older, basaltic shield volcano. South Sister is the youngest of the three composite volcanoes and is composed of andesite, dacite, and small rhyodacite flows (Taylor, 1990). The most recent summit eruption on South Sister occurred during the latest Pleistocene, when the mountain was still covered by a regional ice 
cap (Driedger and Kennard, 1986; Scott, 1977). Flank eruptions of basaltic-andesite have occurred on South Sister between 6 and 15 ka B.P. and rhyodacite approximately 1,700 to $2,100\left(2,000\right.$ to $2,300{ }^{14} \mathrm{C}$ yr B.P.) years ago on both the south and northeast sides (Scott, 1987; Scott and Gardner, 1992). The age of Middle Sister is between its two "siblings" and has a diverse composition similar to both South and North Sisters, ranging from basaltic-andesite to rhyolite (Scott and Gardner, 1992; Taylor, 1990).

Because there has been little detailed mapping of the glacial deposits at Three Sisters, the glacial history has been inferred based on work by Scott $(1974 ; 1977)$ in the adjacent Metolius River area. On the eastern slopes of Mount Jefferson, Mount Washington and Three Finger Jack, Scott $(1974 ; 1977)$ mapped glacial deposits of the late Pleistocene and Holocene. These deposits are separated into the Abbott Butte, Jack Creek, Cabot Creek and Jefferson Park Formations, which represent five glacial advances. The oldest formation is the Abbott Butte, which consists of weathered till and thick, well-developed soils, and is thought to characterize several glacial advances between 200 and 900 ka B.P. (Scott, 1977). The Jack Creek glaciation is the oldest glacial event with preserved moraines and may be correlative with the Hayden Creek glaciation in Washington, which occurred approximately 140,000 years ago (Sherrod et al., in press). The Cabot Creek glaciation followed during the latest Pleistocene (Scott, 1977) and is divided into the older Suttle Lake and younger Canyon Creek advances. The Suttle Lake advance may be correlative with the Evans Creek stade of the Fraser glaciation in Washington ( 20 ka B.P.), while the Canyon Creek stade may be correlative with the Hyak advance (11.0 - 12.5 ka B.P.) (Porter et al., 1983). The 
Jefferson Park event is separated into two phases and is the youngest advance described by Scott (1977). The two glacial advances were restricted to cirques valleys on both Mount Jefferson and Three Finger Jack and are most likely Neoglacial advances, based on their sharp moraine crests and lack of soil development (Scott, 1977).

Work at the Three Sisters by Dethier (1980a; 1980b) and O'Connor et al. (2001) have differentiated at least three Neoglacial age deposits. O'Connor et al. (2001) describes a Little Ice Age advance at Three Sisters that reached its maximum extent roughly $100-300$ yrs. B.P. while the reconnaissance study at South Sister and Broken Top by Dethier (1980a; 1980b) revealed two minor Neoglacial advances or stands occurring between 2.1 and 7.7 ka B.P., which may correlate with the advances in the Metolius River area. Additional work by Sherrod et al. (in press) and Scott and Gardner (1990) have differentiated some late Pleistocene and Holocene deposits that also seem to correlate with the drifts at Mount Jefferson and Washington. My remapping of the glacial deposits at Three Sisters and Broken Top will help refine previous work by Dethier (1980a; 1980b), Taylor et al. (1987), Taylor (1990), Scott and Gardner (1992), O'Connor et al. (2001), and Sherrod et al. (in press). 


\section{Chapter 2: Glacial Deposits and Stratigraphic Sections}

\subsection{Glacial Deposit Mapping}

\subsubsection{Methods:}

To better identify the glacial deposits and associated glacial landforms on the eastern flanks of the Three Sisters volcanoes and the northern flank of Broken Top mountain in the Three Sisters Wilderness area of central Oregon, I focused my mapping efforts on the deposits associated with Linn, Hayden, Diller, Prouty, Lewis, and Bend glaciers. Field mapping was compiled on 1:24,000 scale USGS topographic quadrangle maps, and refined in the office using aerial photographs and digital pictures from the field. To temporally separate the moraine deposits, I used their stratigraphic position, plant/tree/lichen cover, shape and sharpness of crests, height, and surface deposits of tephra. The four most prominent tephra encountered were the Collier Cone, Devil's Hill, Rock Mesa, and Mount Mazama deposits. The Collier Cone tephra is a basaltic tephra, which erupted from Collier Cone (on the nothern flank of North Sister) approximately 1300 to $1700 \mathrm{yrs}$. B.P. $\left(1600 \pm 100{ }^{14} \mathrm{C}\right.$ yr B.P.) (Sherrod et al., in press). Both the Devil's Hill and the Rock Mesa are local rhyolitic tephra from numerous vents on South Sister that were deposited in two episodes between 1700 and 2500 yrs B.P. $\left(2000-2300{ }^{14} \mathrm{C}\right.$ yrs B.P.) (Scott, 1987). Because the Rock Mesa and Devil's Hill tephra are so similar in appearance and mineralogy, as well as age, I did not try to differentiate between the two. The Mazama tephra originated from Mount Mazama, the volcanic peak that once occupied present-day 
Crater Lake ( $\sim 120 \mathrm{~km}$ southeast of the Three Sisters). The Mazama tephra is approximately $7.7 \mathrm{ka}$ yrs B.P. $\left(6845 \pm 50{ }^{14} \mathrm{C}\right.$ yrs B.P.) $($ Bacon, 1983$)$ and provides a good age marker because of its regional extent and distinctive character of coarse, yellow ash with fine lapilli (Scott et al., 1990).

\subsubsection{Results: Moraine Deposits:}

Four or five moraine sets off of the eastern flanks of the Three Sisters record varying positions of the glaciers during the last 14 ka B.P. (Table 2). The innermost moraines are approximately $60 \mathrm{~m}$ high and are sharp-crested with little to no vegetation on their slopes (Figure 7 and Figure 8). Moraine material ranges from coarse silt $(0.02 \mathrm{~mm})$ to boulders $(3 \mathrm{~m})$, has nearly no soil development, and exhibit high erosion rates at the crests and along the flanks. These moraines likely record a Little Ice Age (LIA) advance (150-250 yrs. B.P.) of the glaciers, based on local tree ring chronologies and their stratigraphic position and morphology (O'Connor et al., 2001).

Table 2: Moraine characteristics on the eastern slopes of the Three Sisters and the northern slope of Broken Top mountain. DHRM is Devil's Hill / Rock Mesa tephra. MZ is Mazama tephra.

\begin{tabular}{lccccc} 
& Morphology & Soil Thickness & $\begin{array}{c}\text { Vegetation } \\
\text { Cover }\end{array}$ & Elevation & $\begin{array}{c}\text { Tephra } \\
\text { Cover }\end{array}$ \\
\cline { 2 - 6 } Little Ice Age & $60 \mathrm{~m}$ tall & $0-5 \mathrm{~cm}$ & $<5 \%$ & $2200-2600 \mathrm{~m}$ & None \\
Late-Neoglacial & $20-30 \mathrm{~m}$ tall & $0-5 \mathrm{~cm}$ & $5-10 \%$ & $2200-2300 \mathrm{~m}$ & DHRM \\
Early-Neoglacial & $15-30 \mathrm{~m}$ tall & $30-45 \mathrm{~cm}$ & $10-25 \%$ & $2100-2300 \mathrm{~m}$ & DHRM \\
Fountonnor & $10-20 \mathrm{~m}$ tall & $>45 \mathrm{~cm}$ & $>25 \%$ & $2000-2100 \mathrm{~m}$ & DHRM, MZ \\
\hline
\end{tabular}




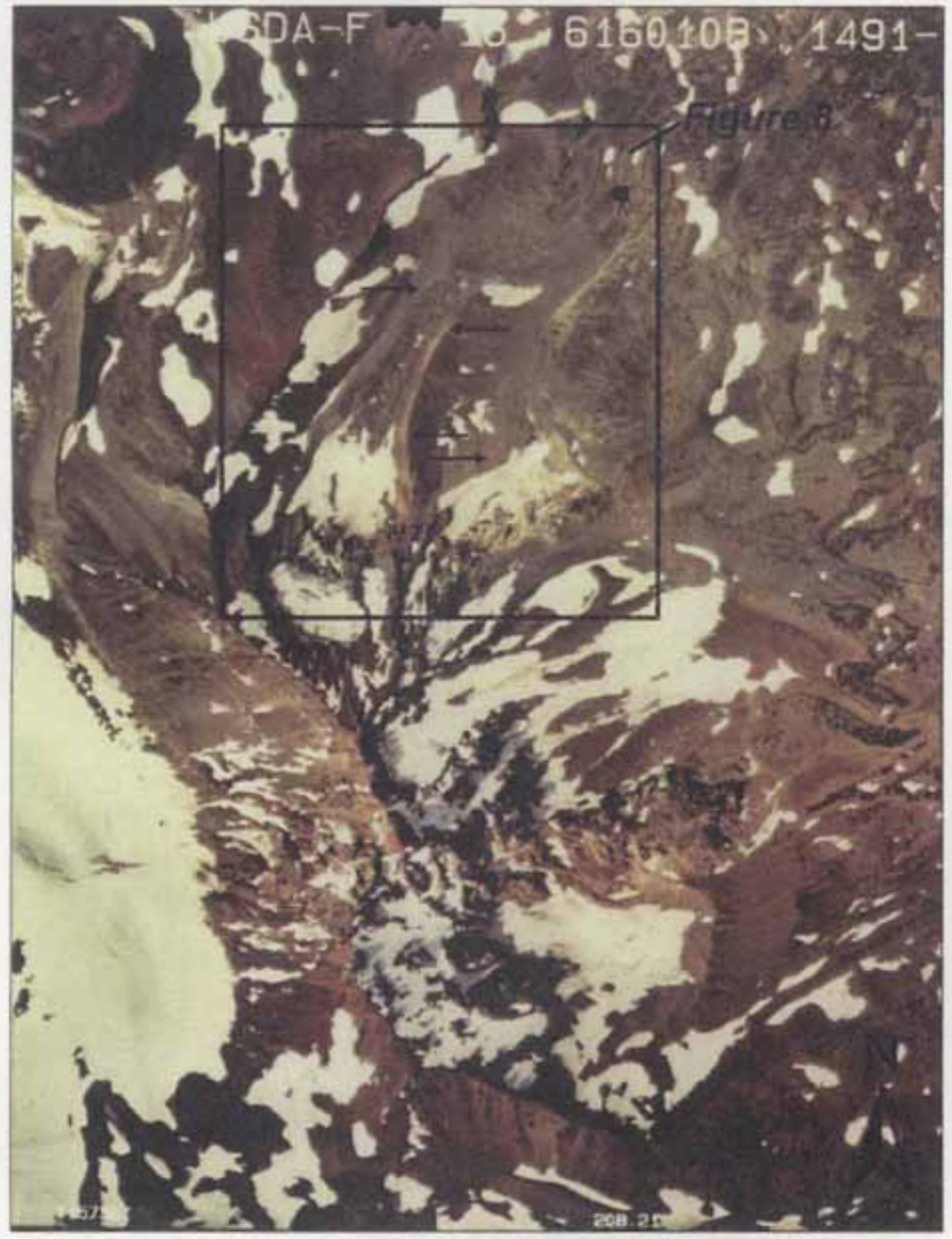

Figure 7: Aerial photograph of North Sister. The black lines outline the area of the photograph from Figure 8. The camera symbol indicates the location of the picture and the arrows depict moraines crests downslope of Linn glacier. 


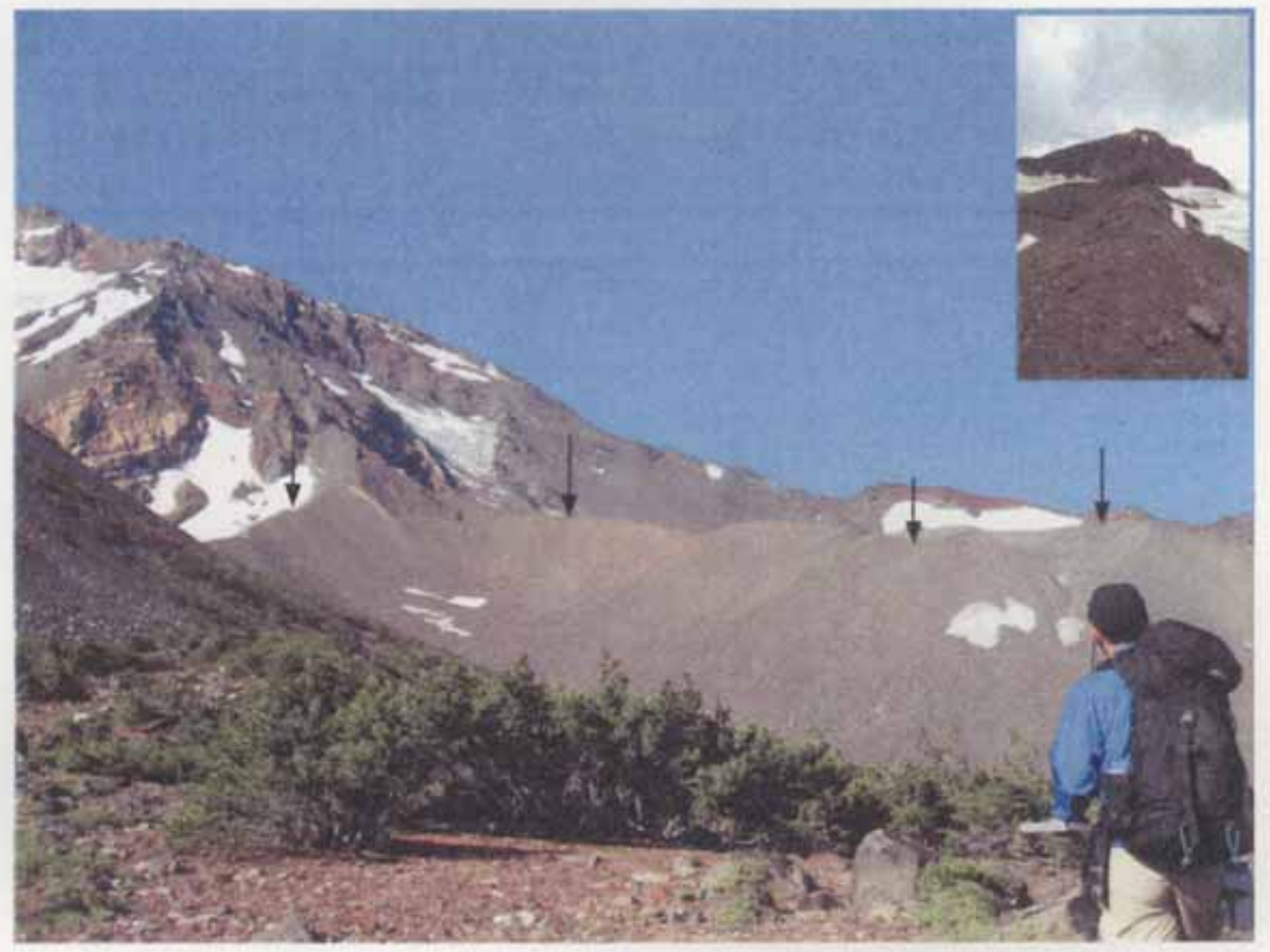

Figure 8: Northeast flank of North Sister with LLA moraines from Linn glacier. For scale, the moraines are approximately $60 \mathrm{~m}$ in height. Arrows depict the moraine crests. Picture in upper right-hand corner is a close-up of a LIA moraine. Andy Urich in foreground.

Locally, less than $100 \mathrm{~m}$ downslope from these moraines, a second set of mostly lateral moraines are found at South and Middle Sister and Broken Top. These moraines are $20-30 \mathrm{~m}$ tall and have steep rounded crests with small shrubs and lichen growing on their slopes (Figure 9 and Figure 10). The moraine material ranges from coarse silt $(0.02 \mathrm{~mm})$ to boulders $(4 \mathrm{~m})$, has some soil development $(<5 \mathrm{~cm})$, and is generally stable along the crests but unstable along the steeper flanks. These LateNeoglacial moraines are blanketed with the Devil's Hill / Rock Mesa tephra on their 
slopes $(\sim 2100 \pm 400$ yrs. B.P.) but are not covered with the Mazama tephra $(\sim 7.7 \mathrm{ka}$ yrs. B.P.).

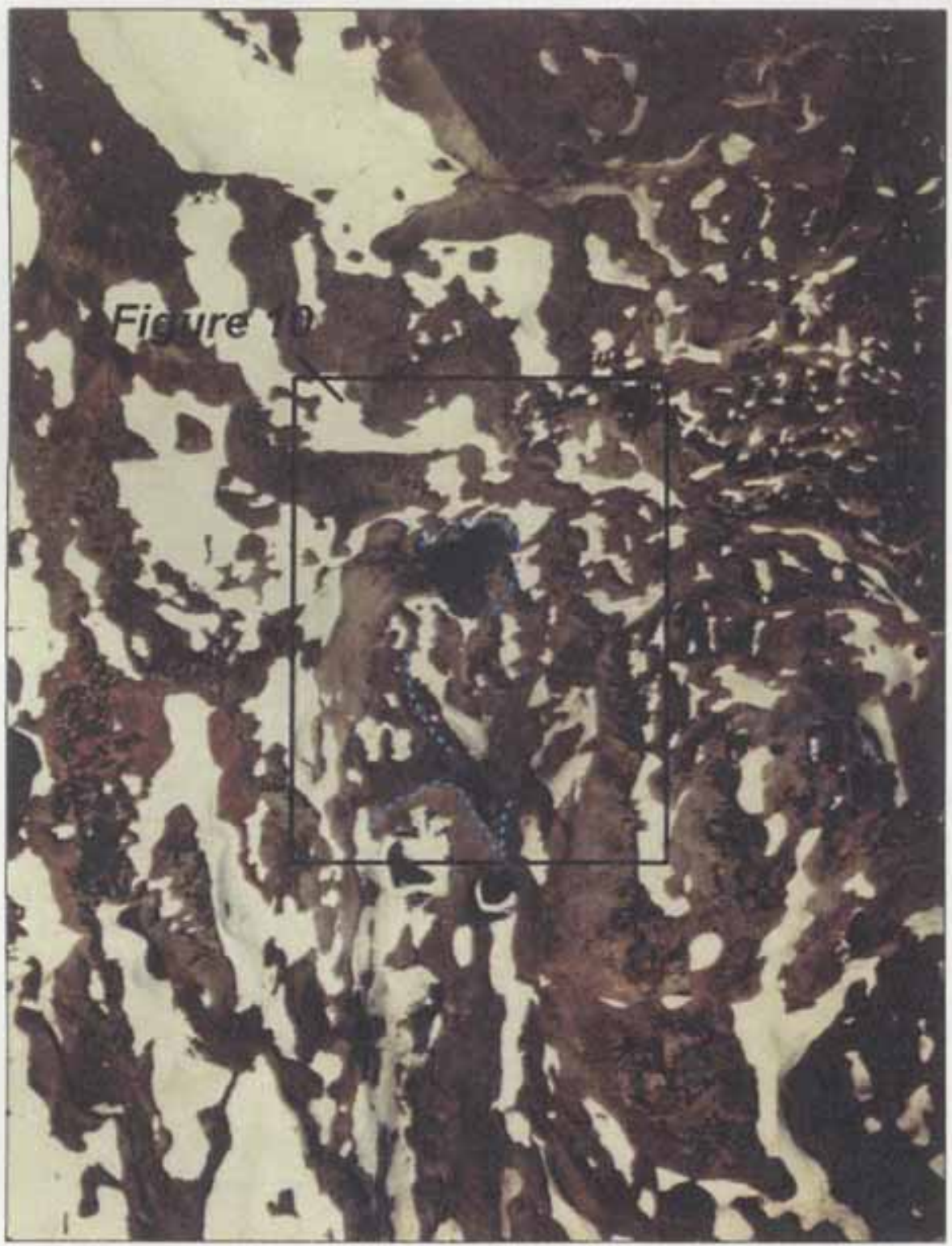

Figure 9: Aerial photograph between Middle and South Sister. The black lines outline the area of the photograph from Figure 10. The camera symbol indicates the location of the picture and the dashed lines depict moraines crests. 


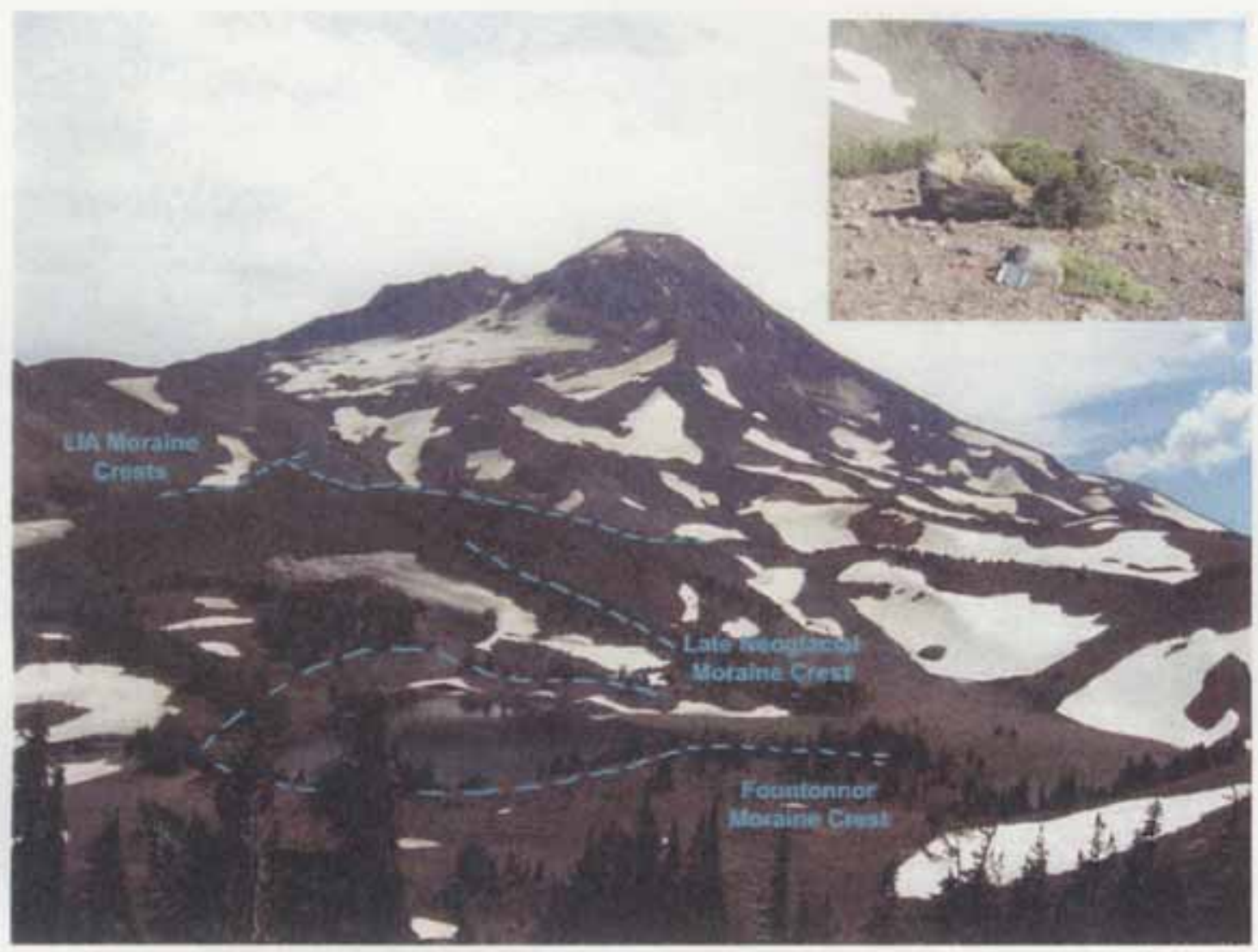

Figure 10: Camp Lake between South and Middle Sisters with LIA, Late-Neoglacial, and Fountonnor moraines extending down the slopes from Carver glacier. Notice differences in vegetation cover and moraine positions. Also, notice that Early-Neoglacial moraines are absent in this moraine set. For scale, the LIA moraines are $60 \mathrm{~m}$ high and the Fountonnor moraines are $\sim 5$ $\mathrm{m}$. Picture in upper right-hand corner is a close-up of a Late-Neoglacial moraine.

Beyond these moraines, a third set exists that is $200-600 \mathrm{~m}$ downslope of the modern glacier termini. This set is $15-30 \mathrm{~m}$ tall and the moraines are nearly flatcrested, with small trees/shrubs and lichen growing on their slopes (Figure 11 and Figure 12). Moraine material ranges from fine silt $(0.01 \mathrm{~mm})$ to boulder $(1 \mathrm{~m})$, has more soil development than the younger moraines $(30-45 \mathrm{~cm})$, and is more stable than the younger moraines along the crests and flanks. These Early-Neoglacial moraines 
are also blanketed with the Devil's Hill / Rock Mesa tephra on their slopes $(\sim 2100 \pm$ 400 yrs. B.P.) and lack Mazama tephra (7.7 ka yrs. B.P.) (Dethier, $1980 \mathrm{a}, \mathrm{b})$.

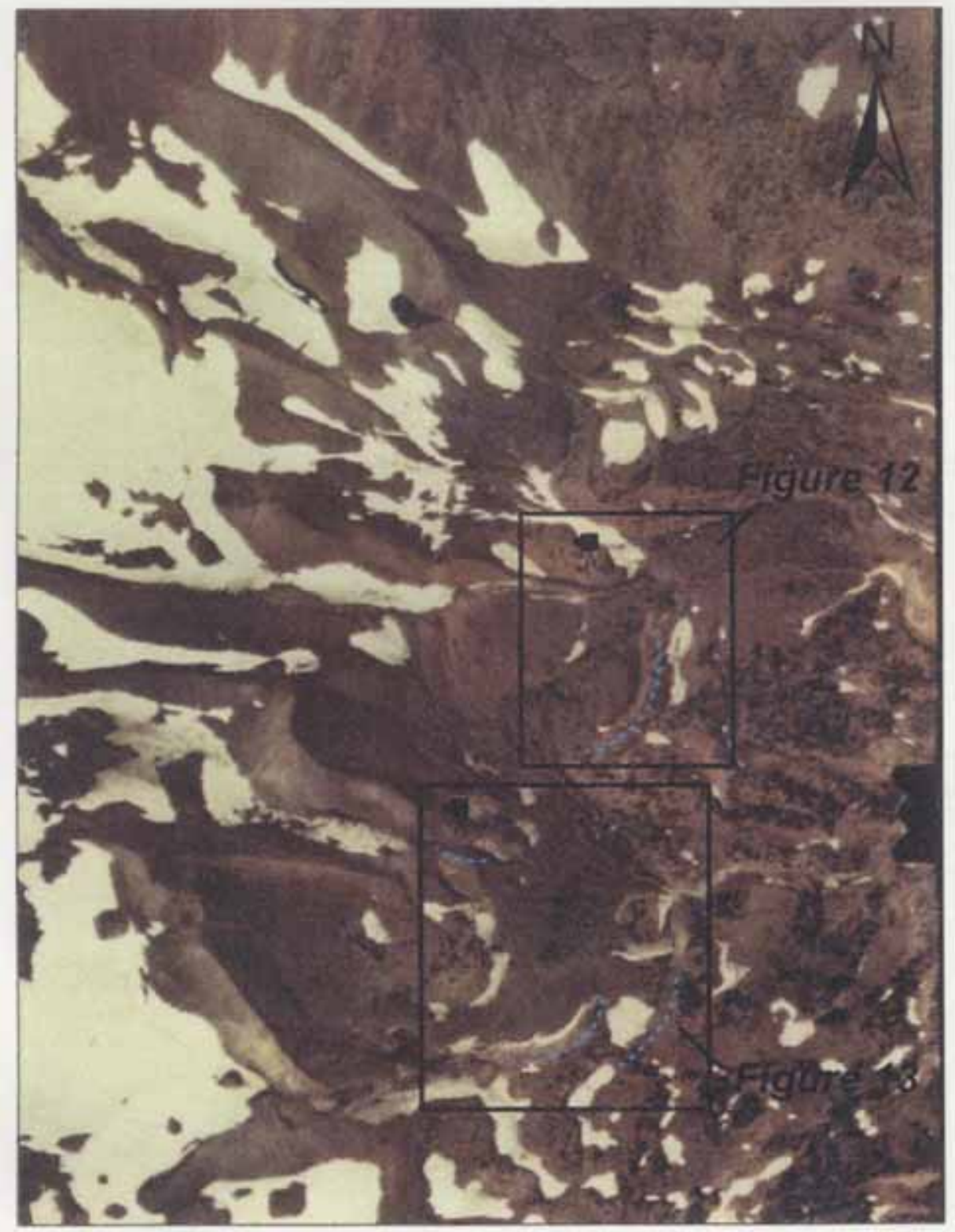

Figure 11: Aerial photograph for Middle Sister. The black lines outline the area of the photograph from Figure 12 and 13. The camera symbol indicates the location of the picture and the dashed lines depiet moraines crests. 


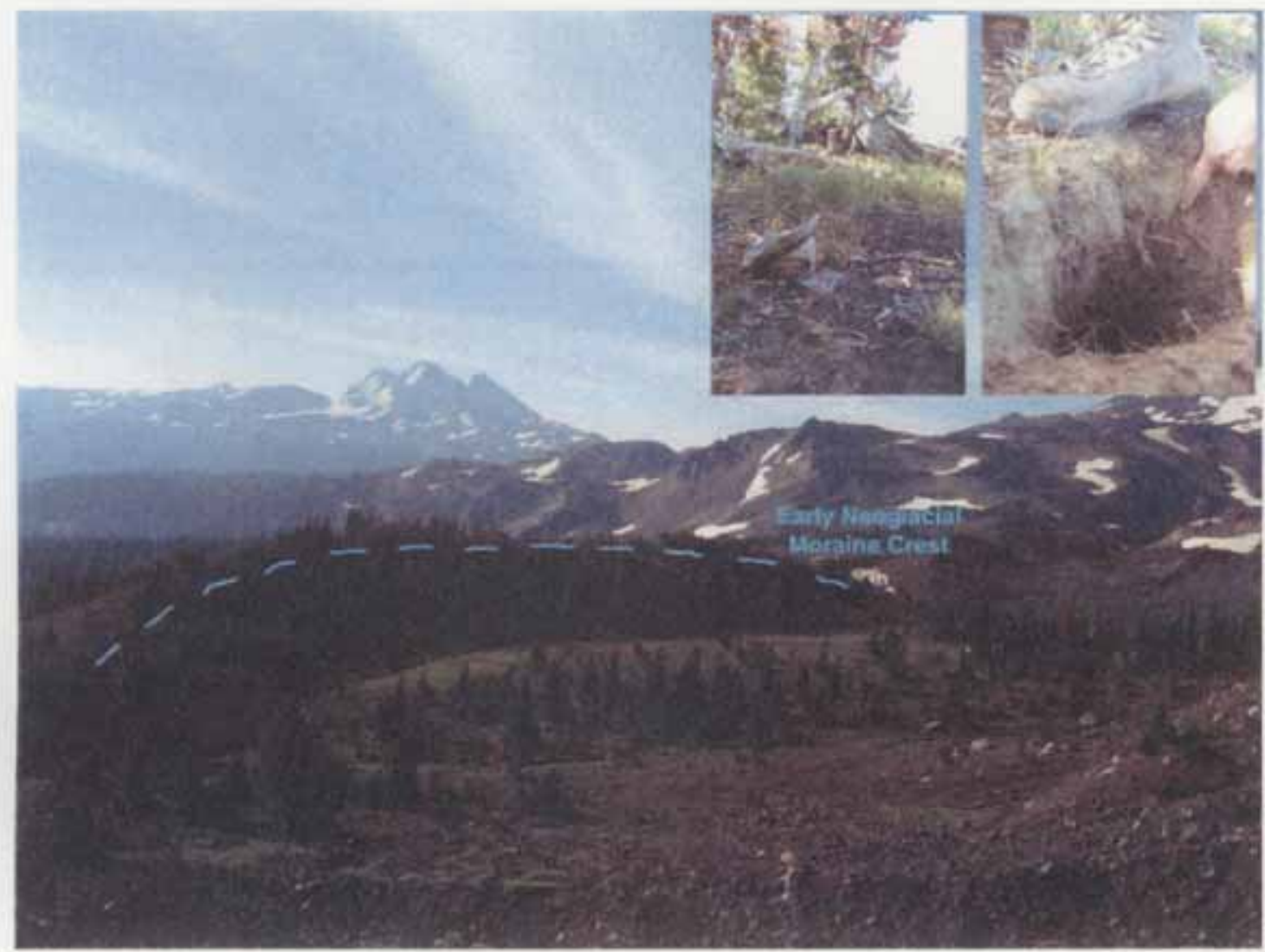

Figure 12: East flank of Middle Sister displaying an Early-Neoglacial end moraine. Notice vegetation cover on moraine flanks and crest. For scale, the moraine is approximately $30 \mathrm{~m}$ high. Pictures in upper right-hand corner are close-ups of an Early-Neoglacial moraine.

A fourth set of moraines $400-900 \mathrm{~m}$ downslope of the modern glacier termini pre-date $\sim 7.7$ ka yrs. B.P., based on the surficial Mazama ash deposit. Devil's Hill / Rock Mesa tephra $(\sim 2100 \pm 400$ yrs. B.P. $)$ was also present on the surface of the moraines. These moraines are more weathered and have more soil development $(>45$ $\mathrm{cm}$ ) than the moraines previously described. These moraines are 10-20 m tall, with nearly flat crests and $1-3 \mathrm{~m}$ tall shrubs and trees on their crests and flanks (Figure 10, Figure 11 and Figure 13). The moraine material ranges from fine silt $(0.01 \mathrm{~mm})$ to boulders $(1 \mathrm{~m})$, has medium soil development $(5-35 \mathrm{~cm})$, and is generally stable along 
crests and slopes. In the following text, I refer to these moraines as the Fountonnor (fown-tōn-er) moraine set, to simplify writing within this paper.

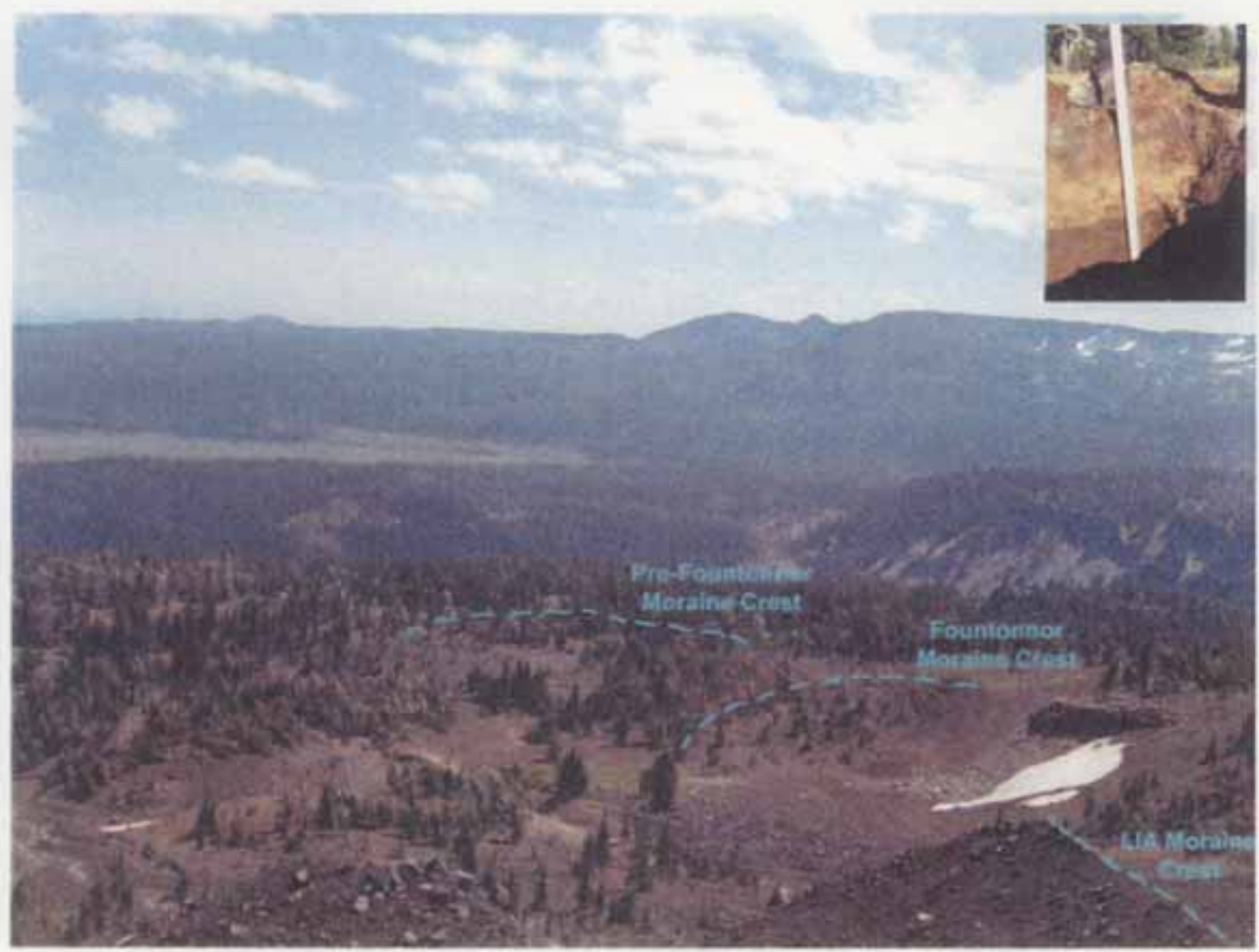

Figure 13: East flank of Middle Sister with LIA, Fountonnor, and pre-Fountonnor moraines extending down the slopes from Diller Glacier. Notice the difference in vegetation cover and deflated moraine heights between the three moraine sets. For scale, the LIA moraines are $60 \mathrm{~m}$ high while the Fountonnor moraine is $\sim 20 \mathrm{~m}$. Picture in upper right-hand corner is a close-up of a Fountonnor moraine.

A fifth and perhaps sixth set of moraines exists $700-1500 \mathrm{~m}$ downslope of the modern glacier termini. These moraines are more weathered than all the previous moraines, with more forest cover on their slopes. Their crests are $<5 \mathrm{~m}$ tall and are subtle in both the field and aerial photographs (Figure 11 and Figure 13). The moraine 
material ranges from clay $(0.05 \mathrm{~mm})$ to boulder $(4 \mathrm{~m})$ in size, has substantial soil development $(>50 \mathrm{~cm})$, and is the most stabilized, due to the abundant tree and vegetation cover. These moraines are overlain by Mazama and Devil's Hill / Rock Mesa tephra. Because detailed mapping and stratigraphic analysis of these moraines is incomplete, and are not a major focus in this thesis, they will not be discussed in detail within this thesis.

\subsubsection{Glacial Deposit Maps:}

The glacial deposits corresponding to the LIA, Late- and Early-Neoglacial (pre-LIA and post-Mazama) and Fountonnor (pre-Mazama) moraines were mapped for the eastern flanks of the Three Sisters and the north flank of Broken Top Mountain (Figure 15 - Figure 18). The LIA and some Late-Neoglacial moraines were originally mapped by O'Connor et al. (2001). The Early-Neoglacial and Fountonnor moraines, which were crudely mapped and not separated into distinct glacial advances/stands by Taylor (1987), Scott and Gardner (1992), and Sherrod et al. (in press) but mapped in detail at Broken Top and parts of South Sister by Dethier (1980a; 1980b), were also further revised. The Fountonnor and Early-Neoglacial deposits corresponding to present Hayden, Diller, Prouty, and Bend glaciers were mapped more completely than the other glaciers on the eastern flanks and have been used to infer the glacial advances/stands for other locations in the Three Sisters study area. 


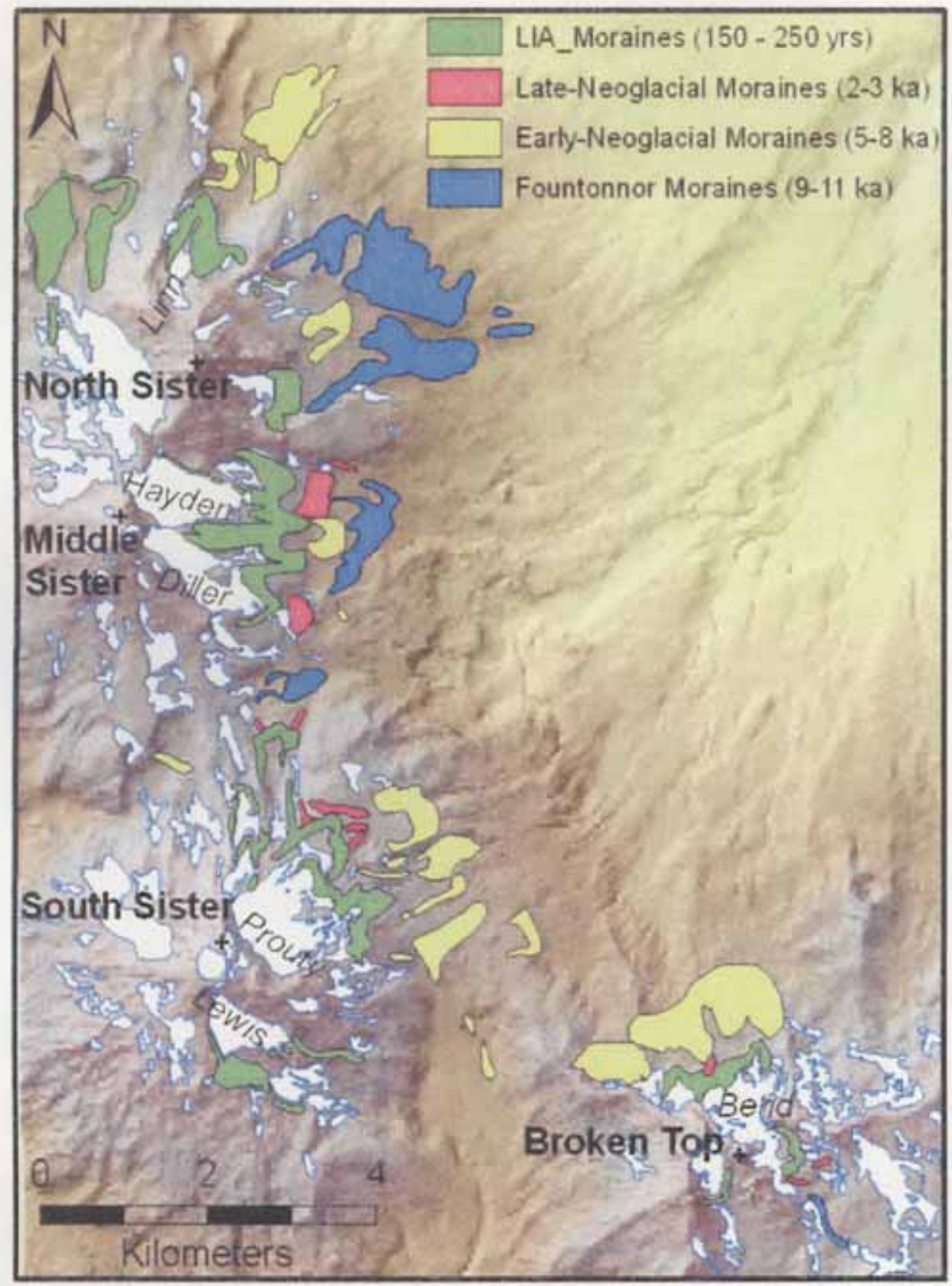

Figure 14: Geomorphologic map of glacial deposits and timing of glacial advances/stands for the Three Sisters and Broken Top mountain. 


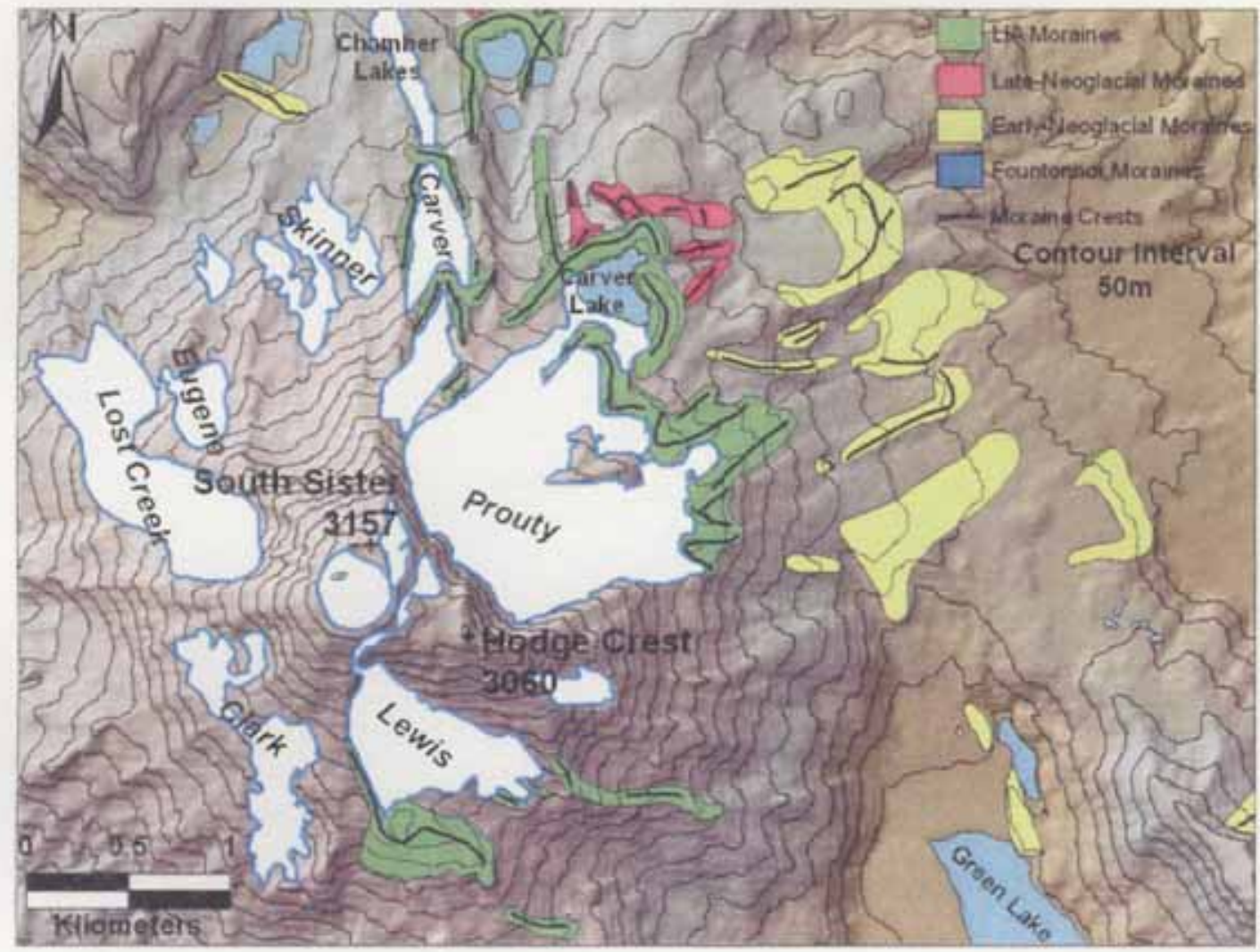

Figure 15: Geomorphologic map of South Sister including current glaciers and snowfields, glacial deposits, and moraine crests on the south, east, and north flanks. Contour interval is $50 \mathbf{m}$. 


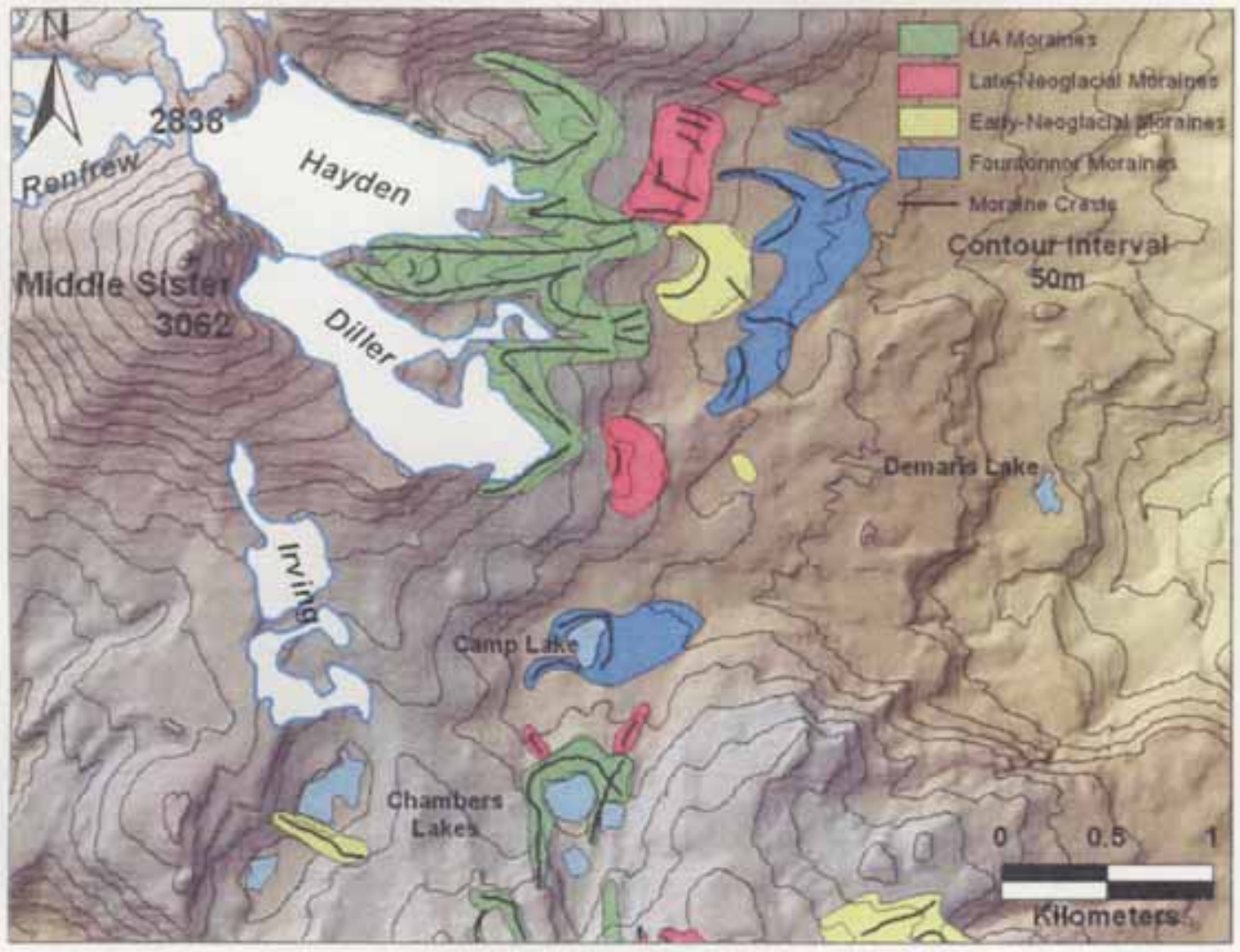

Figure 16: Geomorphologic map of Middle Sister including current glaciers and snowfields, glacial deposits, and moraine crests on the south and east flanks. Contour interval is $50 \mathbf{~ m}$. 


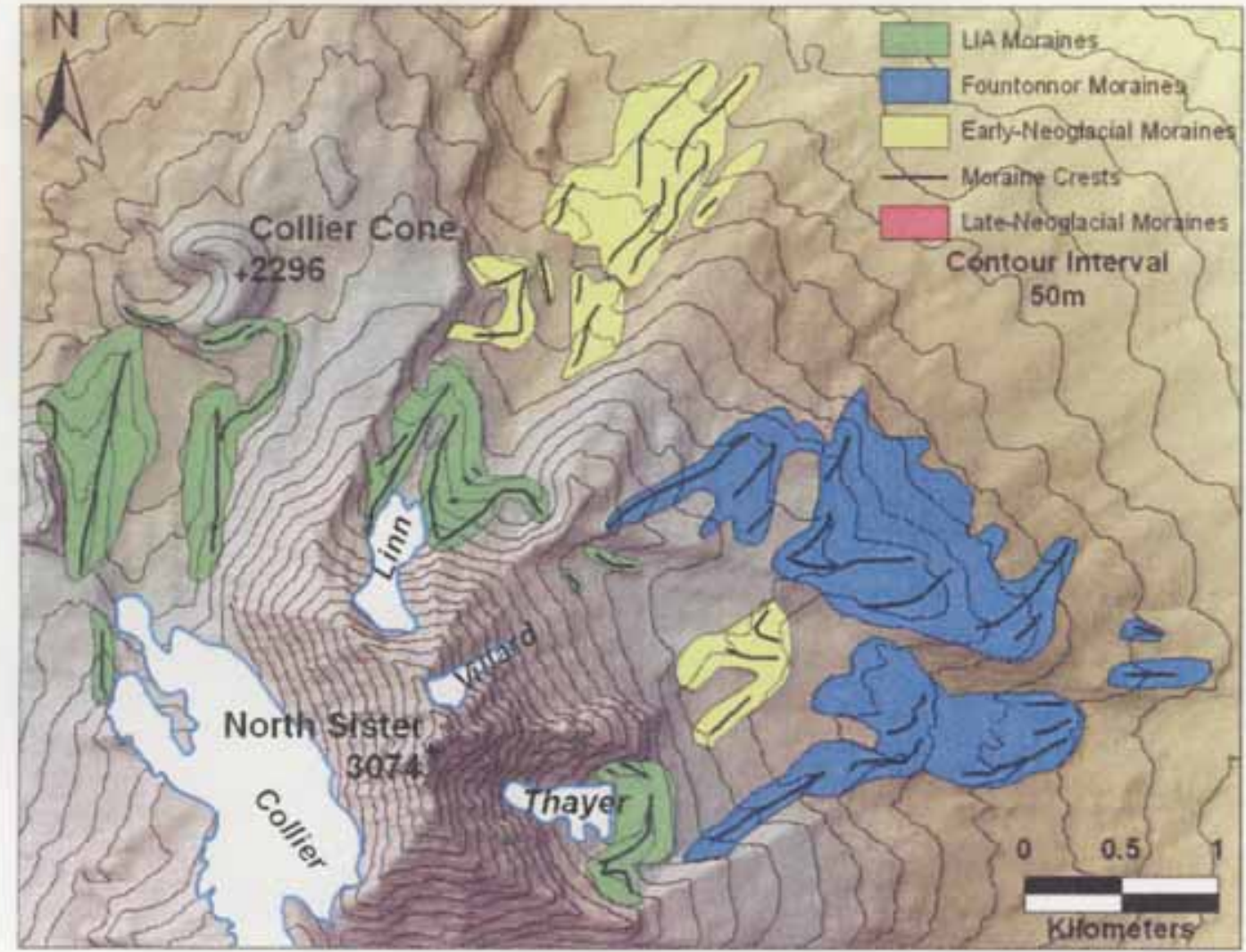

Figure 17: Geomorphologic map of North Sister including current glaciers and snowfields, glacial deposits, and moraine crests on the east and north flanks. Contour interval is $50 \mathrm{~m}$. 


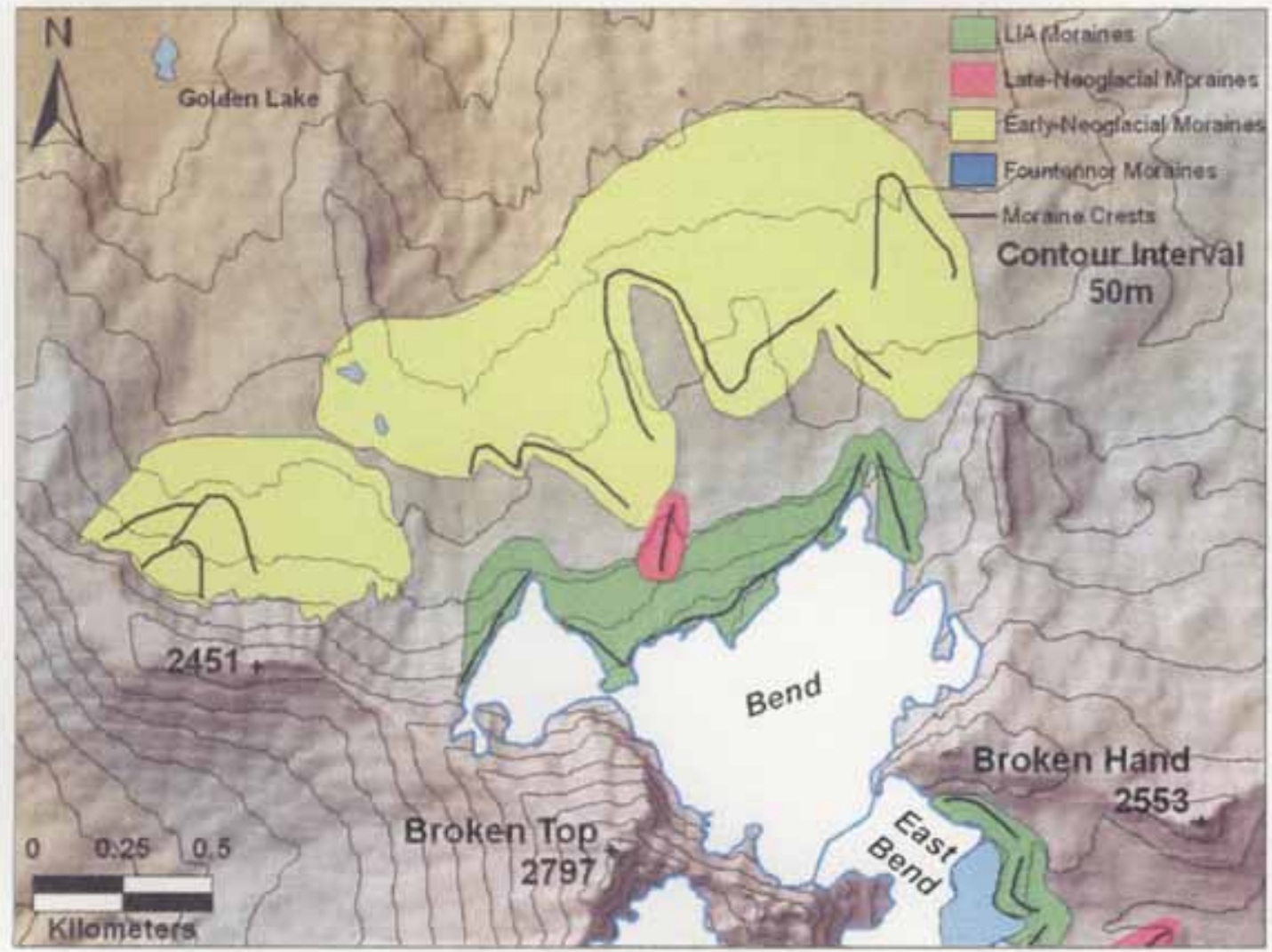

Figure 18: Geomorphologic map of Broken Top including current glaciers and snowfields, glacial deposits, and moraine crests on the north and south flanks. Contour interval is $50 \mathrm{~m}$. 


\subsection{Chronology}

\subsubsection{Methods:}

The stratigraphy and sedimentology of the glacial deposits at the Three Sisters and Broken Top were interpreted from 8 auger holes, from stream cutbank exposures along the North Fork of Squaw Creek, and from a sediment core from Camp Lake, located between Middle and South Sisters. The collection sites were recorded on USGS topographic 7.5' quadrangle maps and the auger holes were located with a Garmin $^{8}$ global positioning system (eTrex Legend), with an error of $\pm 15 \mathrm{~m}$. The stratigraphy was described in the field, and samples were collected and stored in cotton bags labeled with site location, sample number, date, and a brief description of notable, nearby landmarks. Organic material and organic-rich deposits collected at the sites were stored in plastic sample bags in the field, frozen or refrigerated upon return to the laboratory, and finally thawed, dried, and analyzed. Lake sediment cores were collected and stored in steel tubes in the field. After returning from the field, the lake cores were removed from the metal tubes, encased in plastic kitchen wrap, and placed into split PVC pipes for storage. The cores were then refrigerated at $4-8^{\circ} \mathrm{C}$ until they were finally split, photographed, analyzed, and sampled. Half of each core was archived and stored in a refrigerator at the same temperature.

Auger sites were chosen to maximize the likelihood of obtaining dateable material. The majority of the sites chosen for augering were in bogs, meadows, and other flat areas adjacent to the glacial deposits. These bogs and meadows probably are remaines of former moraine-dammed lakes directly fed by the pre-existing glaciers, 
similar to present day Camp Lake, where the lake core was recovered (Figure 16). By assuming a simplified depositional environment at these moraine-dammed lakes (Figure 19), I could infer a minimum and maximum age of the glacial deposits.

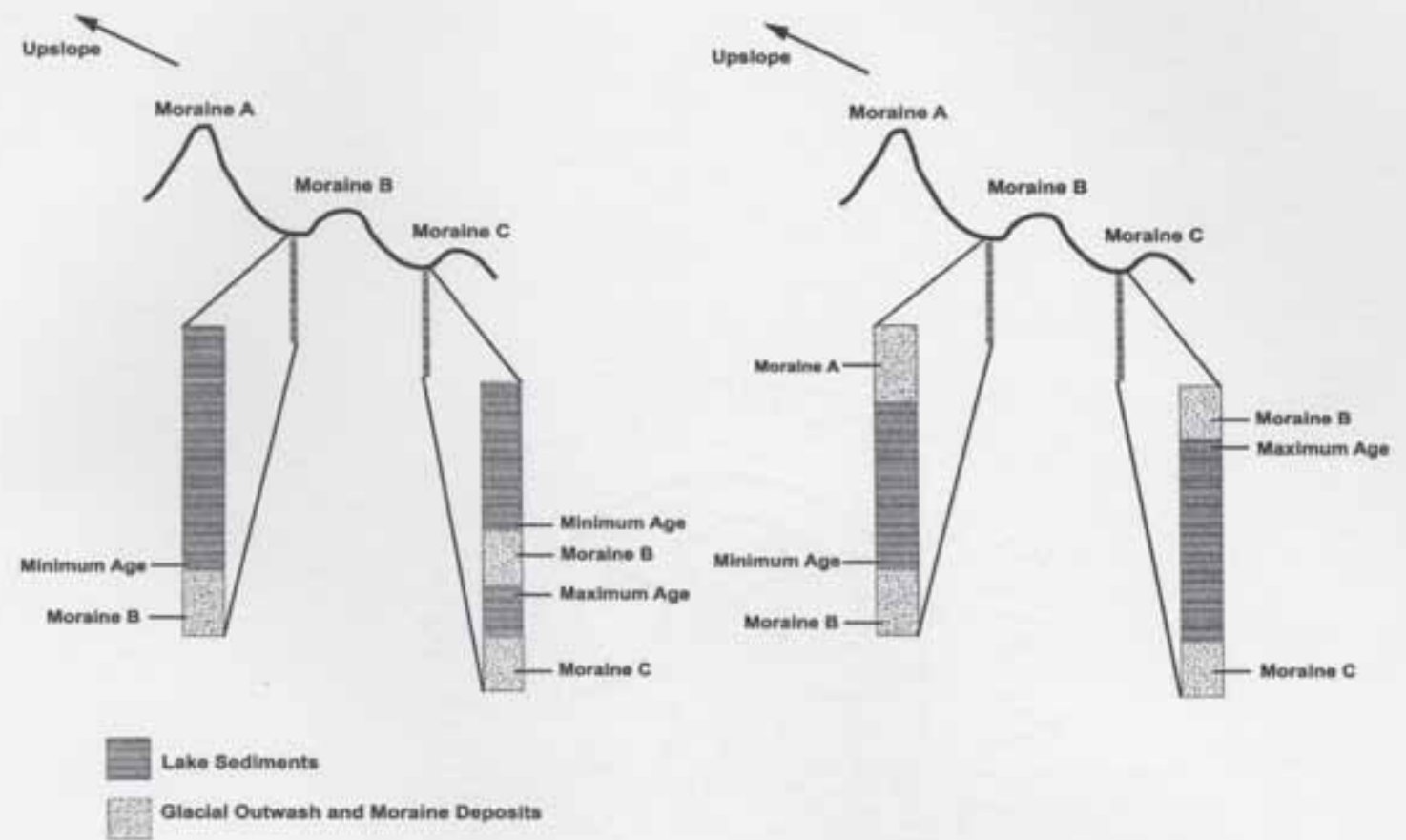

Figure 19: Schematic of two scenarios of a simplified depositional environment associated with two moraine-dammed lakes (adapted from Heine, 1997). In the left scenario, lake sediments that are directly upslope of the moraines are at or near the surface. Lake sediment collected behind moraines $B$ and $C$ are easily obtained and a minimum date of the moraine's deposition can be established. Lake sediments upslope of moraine $\mathrm{C}$ can also give bracketing dates of moraine B's deposition, assuming the glacial outwash associated with moraine B can be penetrated. In the right scenario, outwash and morainal material directly upslope of the moraines is at or near the surface. In this situation, lake sediment samples collected behind both moraine $B$ and $\mathbf{C}$ cannot be obtained because outwash from the upslope moraines is typically too coarse to penetrate.

Sediment cores were collected from Camp Lake during April of 2005, while the lake was still frozen, so the ice could act as a platform for coring. The cores were obtained using a Livingston Corer, provided and operated by Dr. Doug Clark and Ms. Niki Bowerman of Western Washington University (Figure 20). The corer had a $1 \mathrm{~m}$ 
long, $5 \mathrm{~cm}$ diameter, stainless steel core barrel with a piston inside. The corer was connected to the surface by a series of magnesium-zircon core rods and the piston was connected with a thin steel cable. The magnesium-zircon core rods were used to drive the core barrels into the sediment in $1 \mathrm{~m}$ increments. As the corers were driven into the lake sediments, the piston was held in place at the top of the barrel by the steel cable. This created a vacuum in the barrel and held the sediments in place during extraction. Once the steel barrel was full, the core barrel was brought to the surface, switched with a new barrel, and the procedure was repeated until the corer hit refusal within the sediments. 

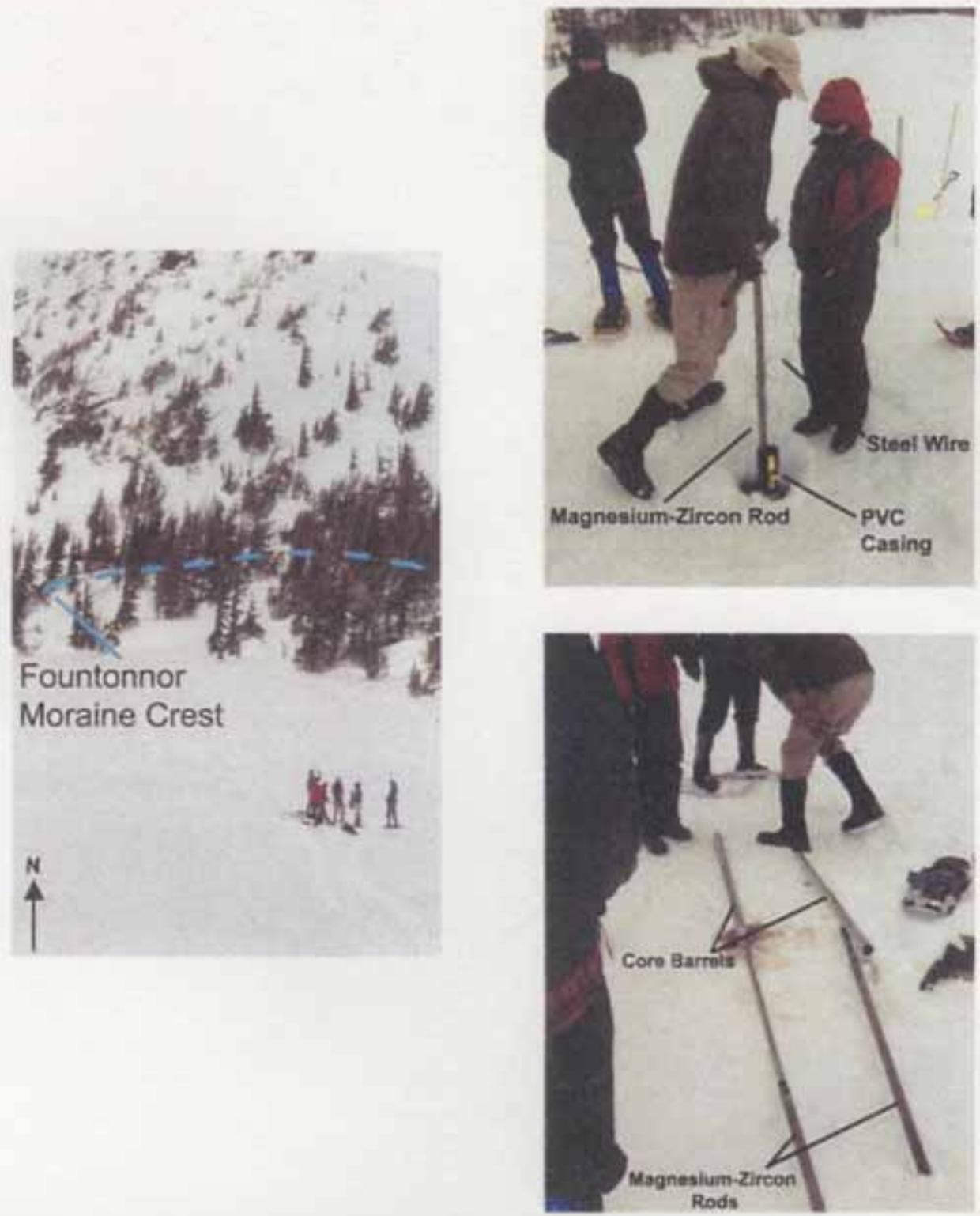

Figure 20: Lake coring photographs from Camp Lake during April of 2005. Doug Clark and Niki Bowerman of Western Washington University shown operating the Livingston corer.

Radiocarbon dates for the collected organic material were analyzed by BETA Analytic Inc. Radiocarbon ages were calibrated using the CALIB program (Stuiver and Reimer, 1993) and were reported using the $2 \sigma$ confidence interval. Tephra 
deposits collected from the auger pits and river exposures were identified on the basis of descriptions by Scott (1987) and Scott et al. (1990).

\subsubsection{Auger Pit and River Exposure Stratigraphy:}

Auger cores were typically $100 \mathrm{~cm}$ deep with the modern soil comprising the first 5-30 $\mathrm{cm}$ and the rest of the core consisting of sand to gravel sized outwash (Figure 21). The cores typically contained no organic materials and were almost always underlain by impenetrable gravel and cobble-sized glacial outwash or moraine deposits. Tephras found in the cores were either from the local South Sister vents ( $2100 \pm 400$ yrs. B.P.) or from the ancient Mount Mazama eruption ( 7.7 ka yrs. B.P.). The stratigraphy from these cores follows the idealized depositional environment from the left scenario of Figure 19, where an impenetrable cobble layer limited the depth of each core. The only exception was at Site 18 , where the core was limited by the collapsing core walls. The majority of the sediments collected from these cores were sand to gravel in size. These sediments were likely glacial outwash and alluvial deposits from the LIA and modern glaciers. 

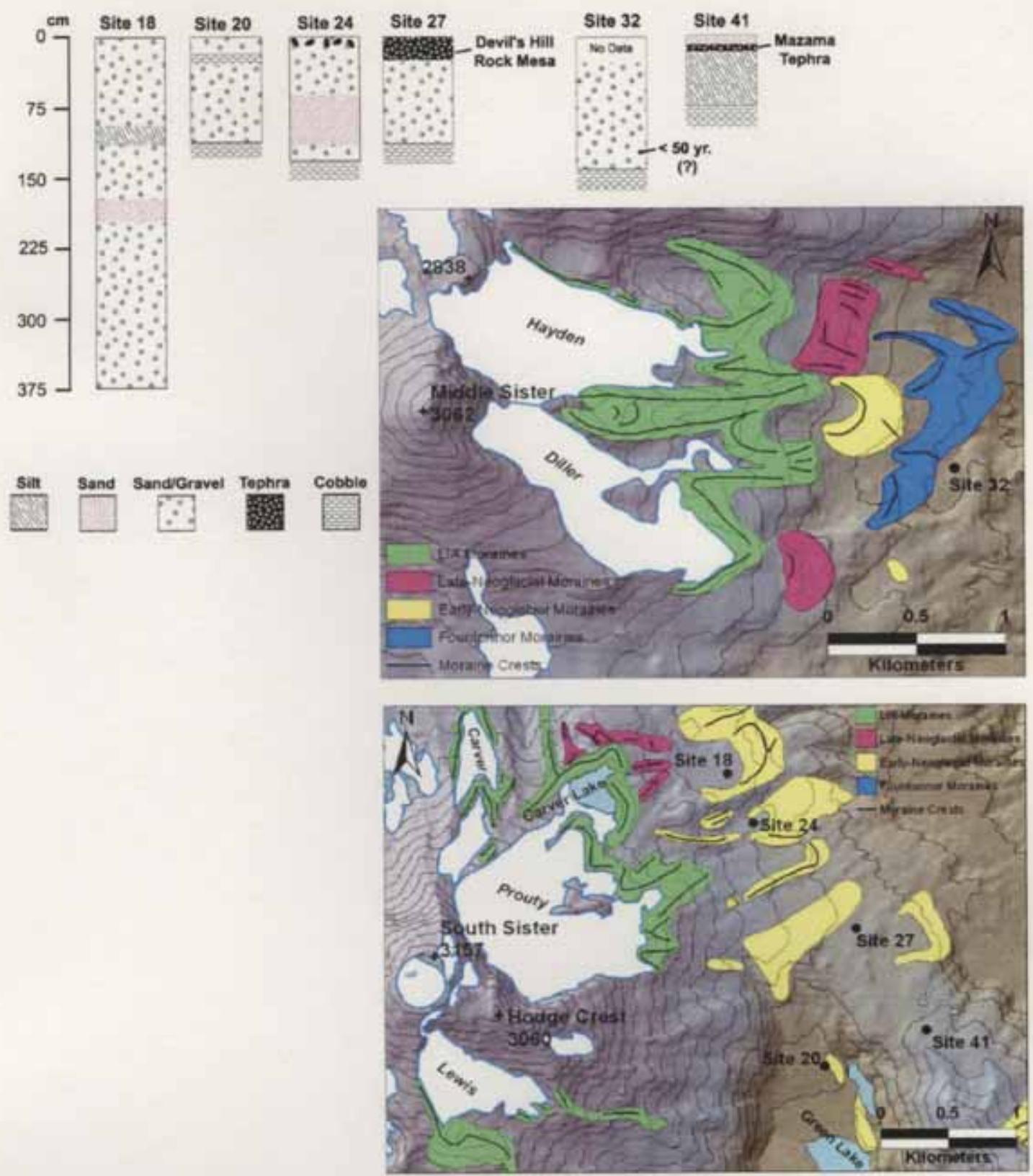

Figure 21: Stratigraphic columns from six auger cores recorded near South and Middle Sisters. No organic rich lake deposits were found in these cores. Detailed stratigraphic sections of these cores are in Appendix. 
The auger cores from Sites 16 and 43, and the river exposures of the North Fork of Squaw Creek, were deeper and revealed more of the stratigraphy than the other cores (Figure 22). The auger cores were 150 to $330 \mathrm{~cm}$ deep, with silt- to claysized particles making up the bulk of the core sediments. The stratigraphy from these auger cores follows the idealized depositional environment from the right schematic of Figure 19, where the cores were far enough away from the glacial outwash of the younger moraines that the lake sediments could be sampled. 

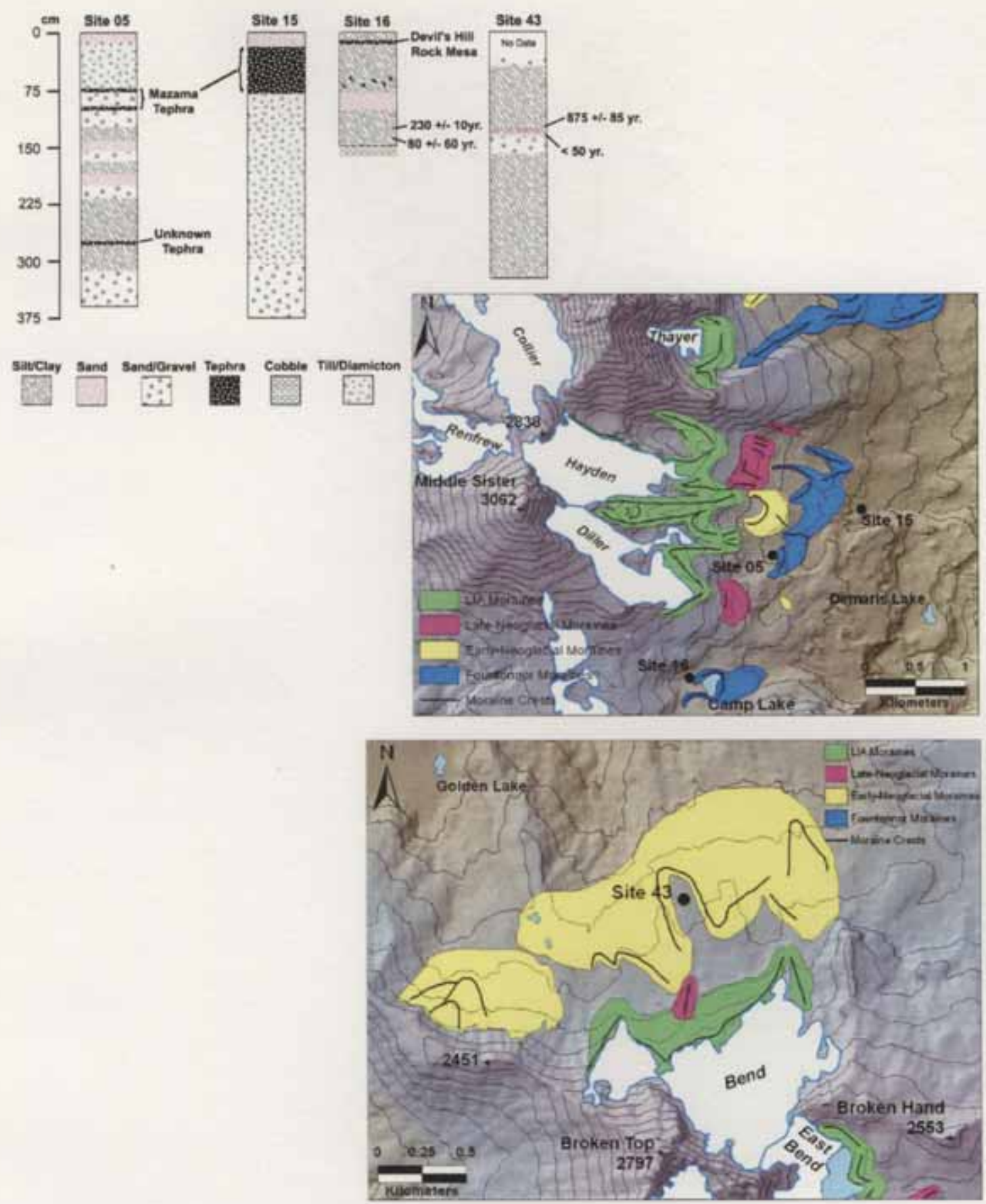

Figure 22: Stratigraphic columns from two auger cores (Sites 16 \& 43) and river exposures (Sites $05 \& 15)$ recorded near Middle Sister and Broken Top Mountain. The only organic rich lake sediments were found at Site 43. Detailed stratigraphic sections of these cores are in Appendix. 
The core at Site 16 near Camp Lake is directly downslope of the Fountonnor glacial deposits. The core collected at the site had a distinct tephra horizon of the Devil's Hill and/or Rock Mesa eruptions ( $2100 \pm 400$ yrs. B.P.) at $20 \mathrm{~cm}$ depth and small pieces of detrital wood near the bottom of the core $(150 \mathrm{~cm})$. These wood fragments dated to $80 \pm 60 \mathrm{yrs}$. B.P. and $230 \pm 10 \mathrm{yrs}$. B.P. If the tephra deposit was in-place, then the organic materials were likely contaminated for radiocarbon analysis during transport to the lab or are younger materials that fell into the core during augering. Alternatively, the tephra deposit could be reworked from the adjoining hills, which would make the dates of the wood fragments valid.

The core at Site 43 near Broken Top Mountain is directly upslope of the EarlyNeoglacial deposits and probably represents the location of a prehistoric, morainedammed lake. The core contained no distinct tephra horizon, and instead abundant organic materials (grass) were found at 60 to $180 \mathrm{~cm}$ depth. Dates from the grass within the organic-rich mud rendered varying ages. I interpret the date of $875 \pm 85 \mathrm{yr}$. B.P. as more representative of the actual age of the organic material rather than the post-1950 date, which was most likely from collapsed sediments near the top of the hole. Regardless, neither of these dates can be used as a minimum age of the EarlyNeoglacial moraines because the core never reached lakebed deposits. At approximately $180 \mathrm{~cm}$ depth, the mud layer liquefied as it came into contact with the water table, making further extractions impossible.

The river exposures along the North Fork of Squaw Creek ranged from a few meters in the upper reaches (Site 05) to several meters further downslope (Site 15). 
The river exposure at Site 05 has a distinct Mazama tephra layer that underlies a glacial outwash deposit. Several silt, sand, and gravel beds underlie the tephra layer. From $130 \mathrm{~cm}$ to $225 \mathrm{~cm}$, the sediments grade from gravel at the base to silt at the top. These gradational beds may represent a time when Squaw Creek was meandering across the surface before it incised the path it follows today. Laminated silt deposits sit below the gradational beds. These silts were likely part of the moraine-dammed lake deposit. Macroscopic organic matter in the silt layers was absent precluding radiometric dating. Approximately $600 \mathrm{~m}$ downslope of Site 05 , the exposure of rivercut sediments increased to $\sim 10 \mathrm{~m}$. At Site 15, a clearly visible Mazama tephra deposit directly overlies what I have interpreted as a Fountonnor till, thus giving a perfect relative age marker for the moraine deposit (Figure 23).

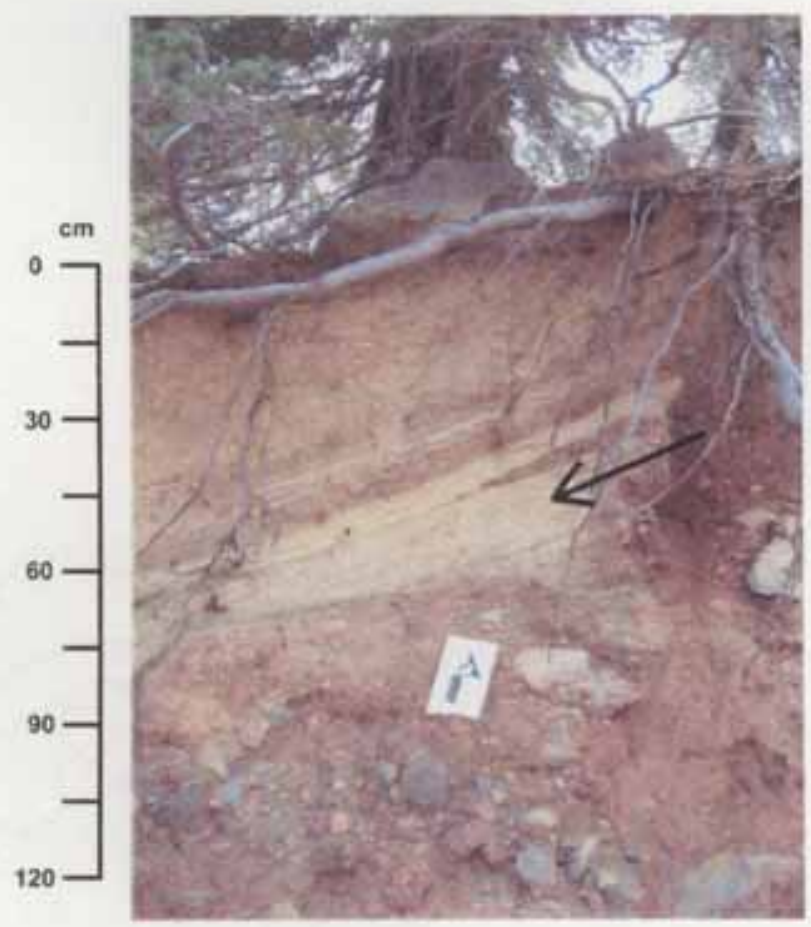

Figure 23: Photograph of Fountonnor till directly overlain with Mazama tephra (arrow). 


\subsubsection{Lake Core Stratigraphy:}

A single lake core was collected between Middle and South Sister at Camp Lake, which is dammed by a Fountonnor end moraine (Figure 24). The core was 160 $\mathrm{cm}$ long and was composed of fine silt- and clay-sized lake sediments and sand- to gravel-sized tephra deposits (Figure 25). No apparent organic material for radiocarbon dating was recovered from the core (e.g. sticks, leaves, seeds, etc.). The first $45 \mathrm{~cm}$ of the core was composed of lake muds that alternated in color from light to dark brown (Munsell color code: 10YR - 2/2, 3/2, 3/3, 3/4, 4/3, and 4/4) (Figure 26). This alternating color pattern indicates that there was little or no mixing in the lake, otherwise the deposits would be more massive and uniform. A small $(\sim 5 \mathrm{~cm})$ deposit of fine sand at $\sim 15 \mathrm{~cm}$ depth, with sharp contacts, was found within the mud layer. Directly underlying the lake muds between $45-50 \mathrm{~cm}$ depth was a basaltic tephra probably erupted from Collier Cone near North Sister at $1500 \pm 200$ yrs. B.P. (Figure 27) (Scott, 2005). Below the basaltic tephra deposit was $5 \mathrm{~cm}$ of lake muds, followed by $45 \mathrm{~cm}$ of Devil's Hill / Rock Mesa tephra (50 - $95 \mathrm{~cm}$ depth) that was deposited $2100 \pm 400 \mathrm{yrs}$. B.P. The rhyolitic tephra contained small pieces $(<1 \mathrm{~cm})$ of red cinters below $\sim 70 \mathrm{~cm}$ depth (Figure 28). The remainder of the core $(95-155 \mathrm{~cm}$ ) was composed of red oxidized mud ( $2.5 \mathrm{YR}-3 / 4$ and $3 / 6)$, with faint remnants of alternating color bands, similar to the mud at the beginning of the core, but faded due to the oxidation (Figure 29). The oxidation of these lake sediments was most likely caused by the lake drying up, thus exposing the sediments to the surface where they began to oxidize. Because Camp Lake is glacier-fed, this drying of the lake may 
indicate a glacial retreat. The large increase in the magnetic susceptibility through the bottom-most mud layer is consistent with the oxidized state of the core. The very bottom of the core contained some gravel-sized pieces of basalt that were impenetrable during coring.

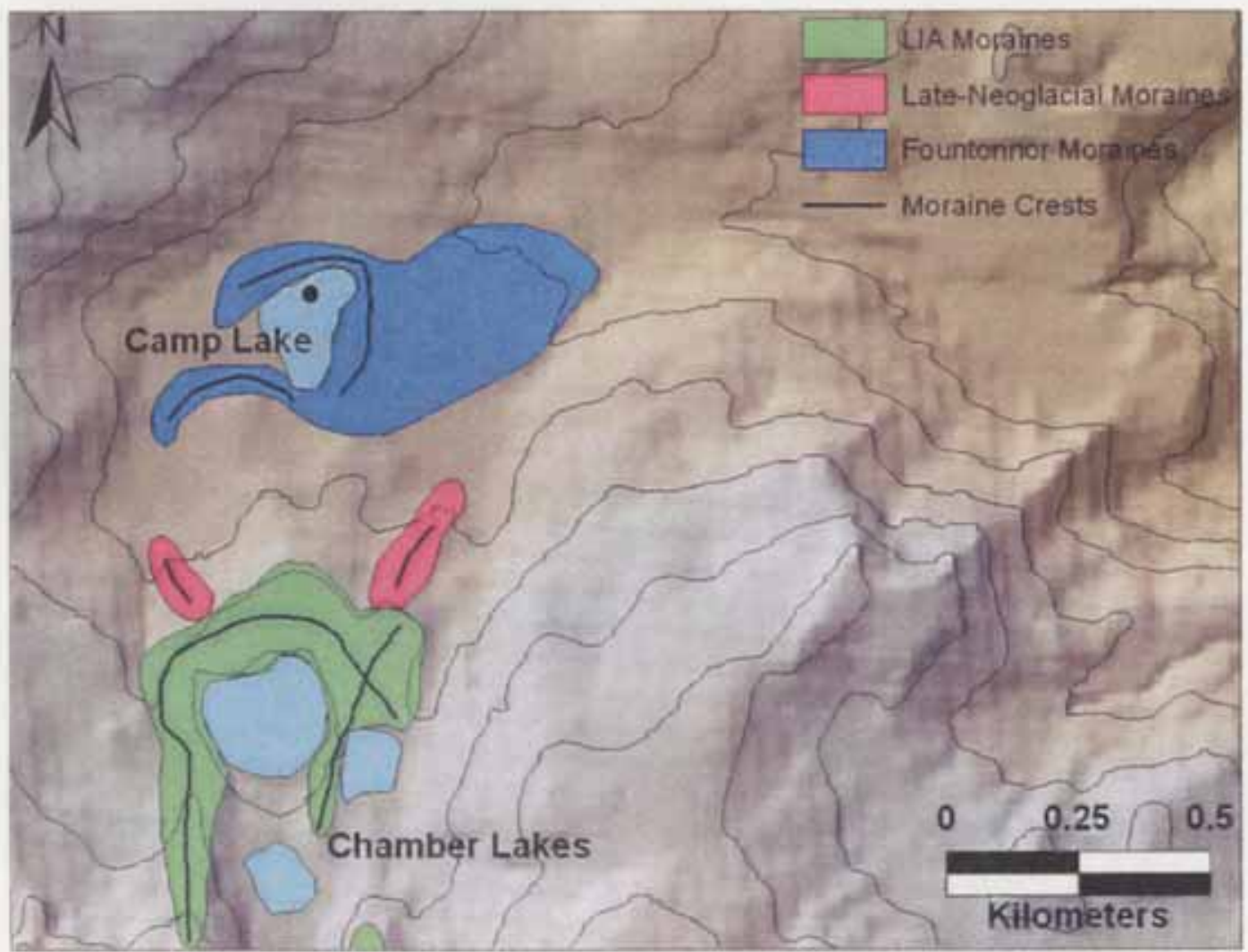

Figure 24: Geomorphologic map of glacial deposits and moraine crests near Camp and Chamber Lakes between Middle and South Sisters. The black dot is where the sediment core for Camp Lake was collected. Contour interval is $50 \mathrm{~m}$. 


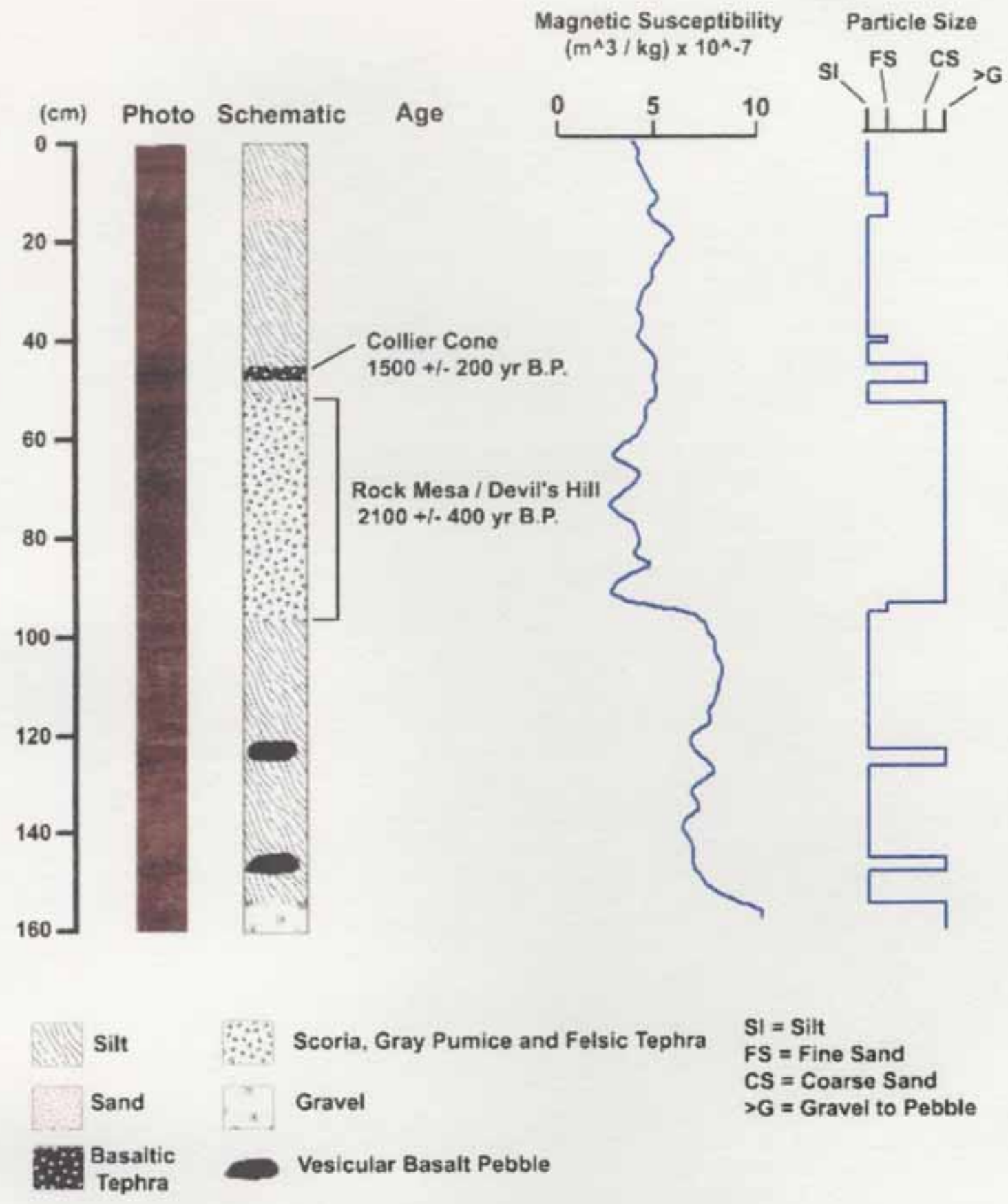

Figure 25: Diagram of Camp Lake core with magnetic susceptibility and generalized particle sizes. 


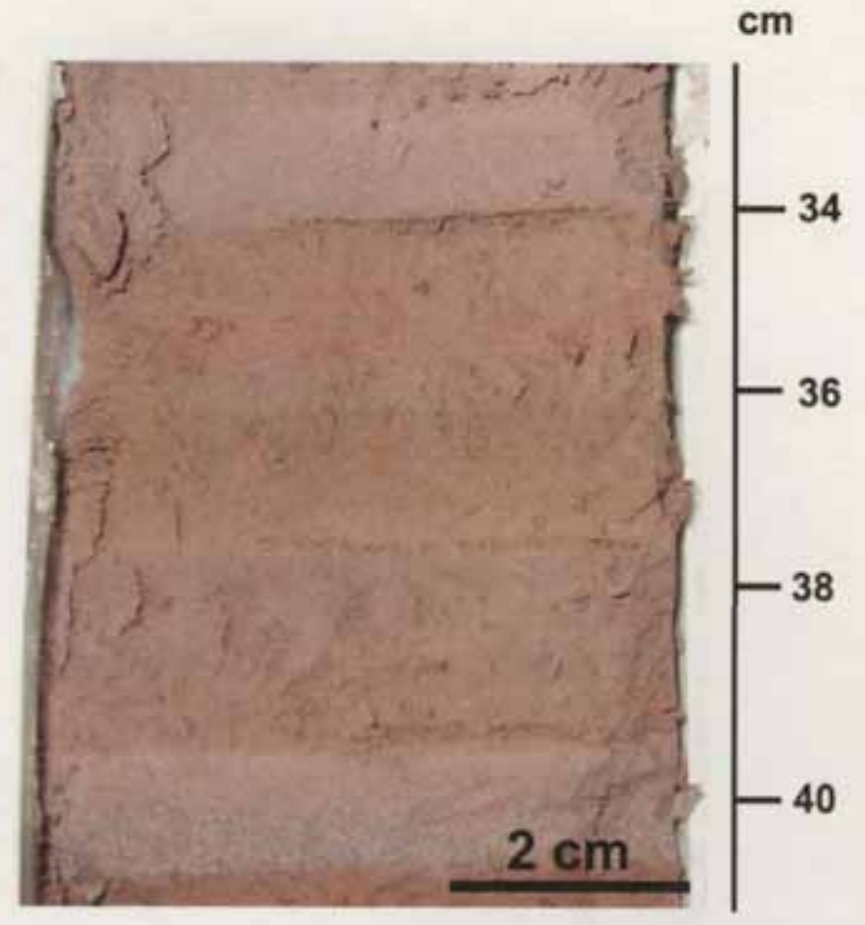

Figure 26: Photo of alternating colors in lake muds in upper section of core $(33-41 \mathrm{~cm})$.

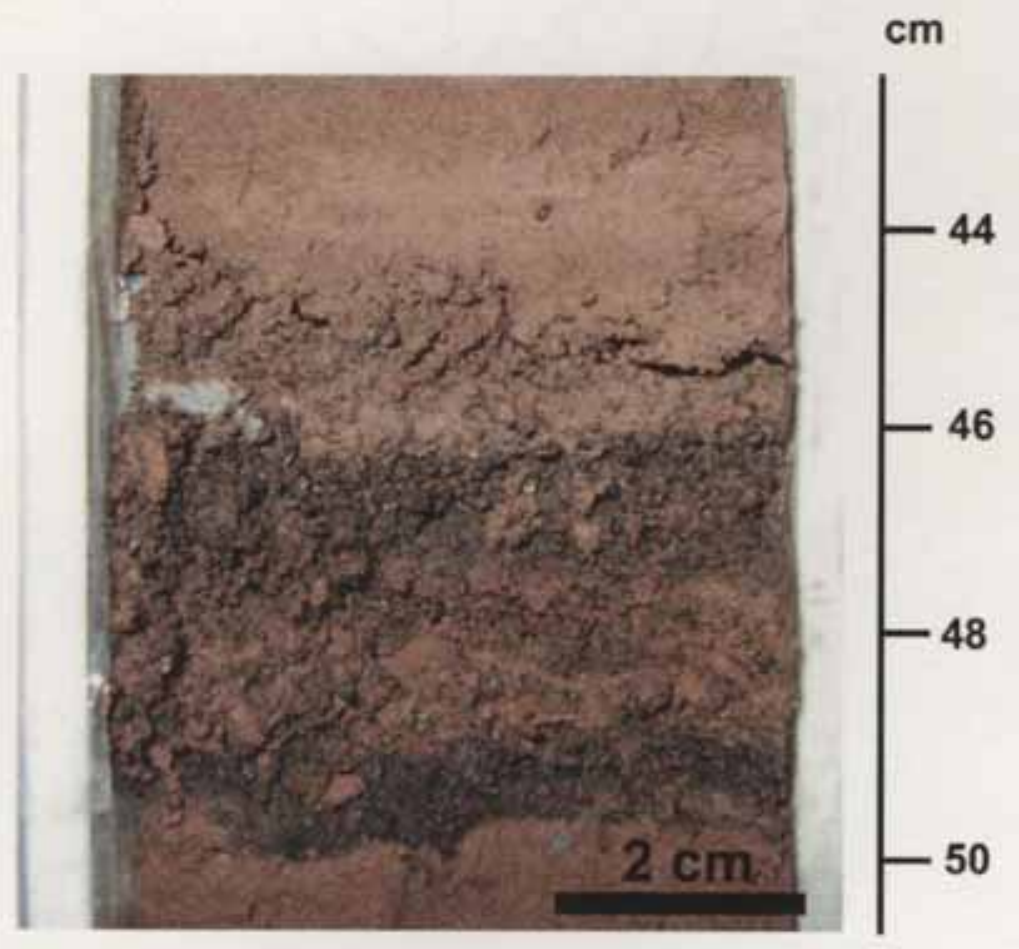

Figure 27: Photo of Collier Cone tephra deposit underlying lake muds $(45-50 \mathrm{~cm})$. 


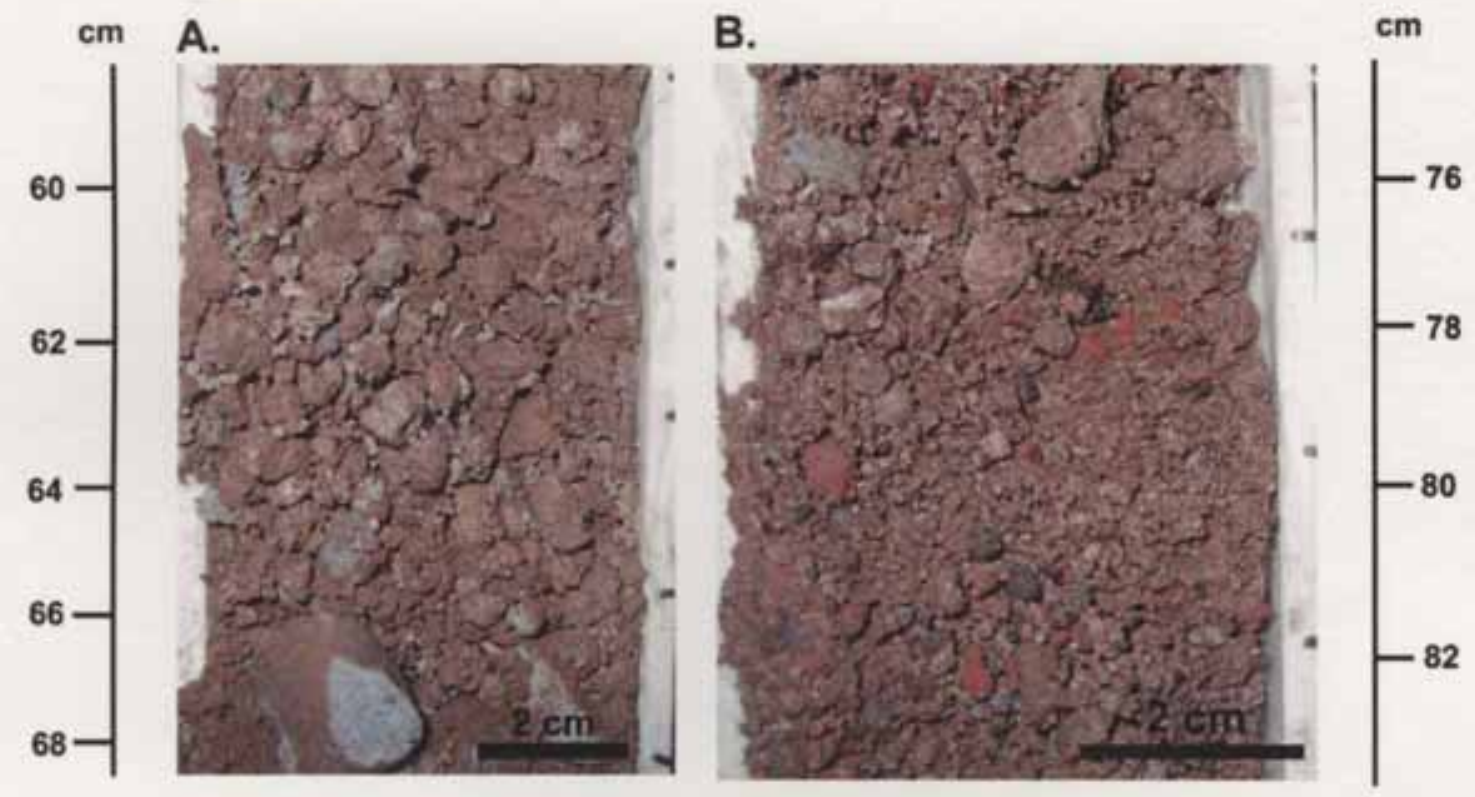

Figure 1: Photos of Devil's Hill / Rock Mesa rhyolitic tephra. Photo A is of the first $10 \mathrm{~cm}$ of the tephra and photo B (with the red sinters) is part of the lower section of the tephra $(75-82 \mathrm{~cm}$ ).

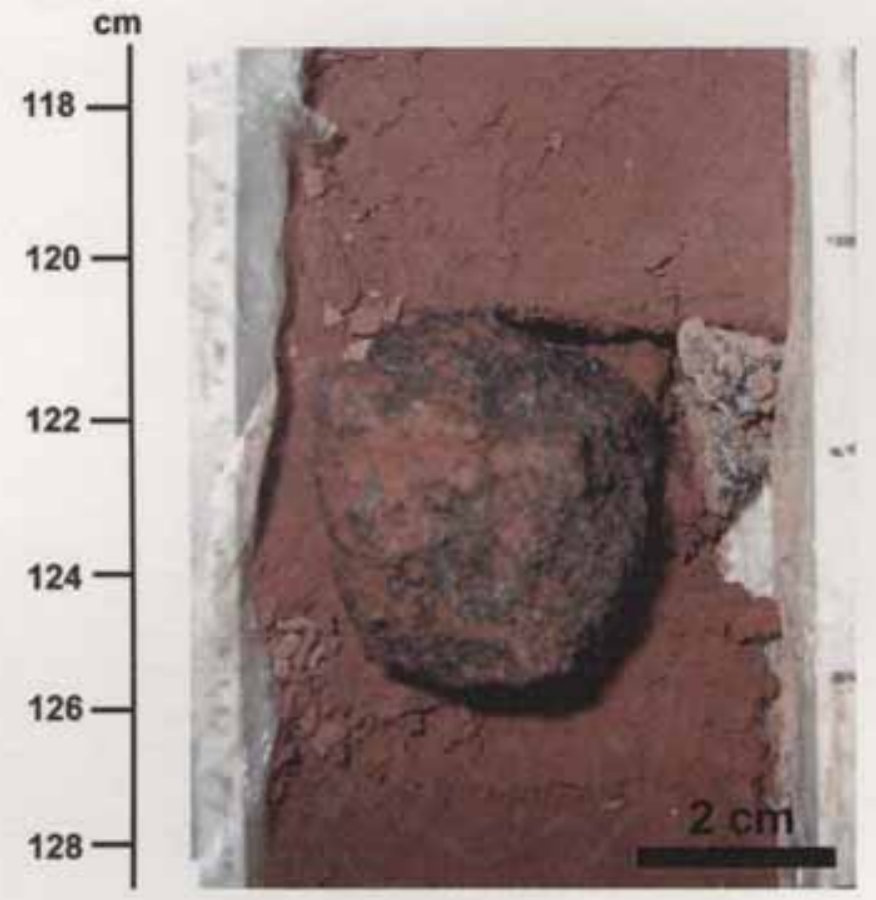

Figure 2: Oxidized lower mud layer with basalt pebble $(118-128 \mathrm{~cm})$. Notice rusty color of the mud layer. 
Because no organic material was found within the mud units, an alternative method of dating the core has been used. Assuming that the deposition of the first 45 $\mathrm{cm}$ of the lake mud was constant, and that the sand unit within the mud was deposited from a short-lived event, such as a flood, the average rate of deposition for the topmost mud unit was $0.028 \pm 0.004 \mathrm{~cm} / \mathrm{yr}$., using the Collier Cone date of $1500 \pm 200$ yrs. B.P. If the rate of deposition was the same for the bottom mud unit, then the lake sediments were deposited in $2210 \pm 320$ years, making the bottom of the oxidized mud about $4310 \pm 720$ yrs. B.P., using the Devil's Hill / Rock Mesa date of $2100 \pm 400$ yrs. B.P. This date is likely a minimum date because it neglects the time it would have taken the bottom mud unit to oxidize to its current state. If the bottom of the core is $4300 \pm 700$ yrs. B.P. and the bottom-most mud unit was oxidized from the lake drying up due to glacial retreat, then the Early-Neoglacial stand of the glaciers must have occurred between the Mazama Ash deposit (7.7 ka B.P.) and some time after the lake dry up at $4300 \pm 700$ yrs. B.P.

\subsection{Summary}

Based on moraines at Three Sisters and Broken Top mountain, the LIA glacial advance at Three Sisters extended 1-2 km from the glacial headwalls. Several small recessional type moraines inside the larger lateral moraine sets suggest other small standstills of the glaciers as they retreated to present positions. Locally, the deposits are similar geomorphically and stratigraphically to the LIA moraines described at Mt. Hood by Lillquist (1988), the phase 1 and 2 moraines of the Jefferson Park advance at 
Mt. Jefferson (Scott, 1974), the LIA moraines of Mount Bachelor (Scott et al., 1990), the Neoglacial II deposits at Mt. McLoughlin (Carver, 1972) and the Lathrop phase 1 and 2 moraines of Mt. Thielson (LaFrenz, 2001). In these local studies the moraine deposits lack Mazama tephra, have little to no soil development, are within $0-300 \mathrm{~m}$ of modern glacier termini, and are well developed with sharp crests. This closely matches the LIA deposits found at Three Sisters, where the lateral and end moraines lack Devil's Hill / Rock Mesa (2,100 \pm 400 ka B.P.) and Mazama (7.7 ka B.P.) tephra, have poorly developed soil horizons, are typically within $50 \mathrm{~m}$ of modern glacier termini, have sparse vegetation cover on their slopes, and are $\sim 60 \mathrm{~m}$ high with sharp crests. These LIA deposits are also analogous to young glacial deposits observed in other regions of the western United States such as Washington (Burrows et al., 2000; Crandell, 1969; Miller, 1969) and Utah (Anderson and Anderson, 1981; Madsen and Currey, 1979). From local tree ring records and other land based temperature data, the LIA advance at Three Sisters likely took place within the last $150-200$ yrs. (O'Connor et al., 2001; Wiles et al., 1996), consistent with the previously mentioned local and regional studies.

The remnant Late-Neoglacial moraines are isolated to only a few localities on the Three Sisters and Broken Top mountain and are difficult to reconstruct and correlate with other advances in the western United State because of the lack of existing morainal material. The moraines could represent a still stand of the glaciers during the retreat from the Early-Neoglacial or Fountonnor moraines but confirming this is difficult. What is known about the moraines is that they formed between $\sim 2$ 
and 8 ka B.P. based on the presence of Devil's Hill / Rock Mesa tephra $(\sim 2100 \pm 400$ yrs. B.P.) overlying the moraines, the lack of Mazama ash ( $7.7 \mathrm{ka}$ yrs B.P.) on the moraine slopes, and the small degree of morainal weathering and vegetation cover.

Based on the Early-Neoglacial moraines at Broken Top and South Sister, the glaciers were more extensive than during the LIA and Late-Neoglacial periods, with the glaciers extending $2-3 \mathrm{~km}$ from the glacial headwalls. From the well-developed lateral and end moraines, the glaciers likely stayed at their maximum positions for a prolonged period ( $>100 \mathrm{yrs}$.) before retreating upslope. The Early-Neoglacial stand at Three Sisters occurred during the mid to early Holocene ( $2.5-8.0$ ka. B.P.) based on the presence of Devil's Hill and/or Rock Mesa tephra and the lack of Mazama ash on the moraine slopes (Dethier, 1980a, b). Locally, the Early-Neoglacial moraines are similar to the Neoglacial I deposits at Mt. McLoughlin (Carver, 1972). Both deposits lie stratigraphically above Mazama tephra, are covered with large amounts of lichen and tree cover, do not have much soil development, and are $<3 \mathrm{~km}$ from the termini of modern glaciers.

Based on the moraines at Middle Sister, the Fountonnor stand at Three Sisters was the furthest the glaciers had been since the latest Pleistocene with the ice extending 3-4 km from the glacial headwalls. The multiple end and lateral moraines that have been preserved from this stand suggest that the glaciers were at their maximum positions for an extensive period (>100 yrs.). Locally, the Fountonnor deposits are stratigraphically and geomorphically similar to the Canyon Creek drift of the Cabot Creek advance at Mt. Jefferson (Scott, 1974) and the Zephyr Lake drift in 
the Mountain Lakes Wilderness (Carver, 1972). Both the Canyon Creek and Zephyr Lake drifts are covered with Mazama ash and both sets of moraines have soil development of $15-45 \mathrm{~cm}$, similar to the Fountonnor deposits at Three Sisters. The Fountonnor stand was pre-Mazama and based on the incorporation of the Mazama tephra in the soil deposits and the amount of weathering of the Fountonnor moraines, the stand may have been within the last 10,000-12,000 years. Consequently, the Fountonnor stand may correlate with the post Younger Dryas advances found at Mt. Rainier (10.4 \pm 0.5 ka B.P.) and the Wallowa Mountains (10.2 \pm 0.5 ka B.P.) (Heine, 1997; Licciardi et al., 2004) to Younger Dryas advances in British Columbia (11.5 \pm 0.3 ka B.P.), the Enchantment Lakes Wilderness (>11.3 ka B.P.) and the San Bernadino Mountains (12.5 \pm 0.5 ka B.P.) (Bilderback, 2004; Owen et al., 2003; Reasoner et al., 1994). 


\section{Chapter 3: Equilibrium Line and Paleoclimate Reconstructions}

The balance between glacier extent and climate is based on the equilibrium line altitude (ELA) of a glacier. Reconstructing the glacier's position with time allows inferences about climate change to be made. The ELA represents the boundary on a glacier between the zone of annual net accumulation (mass gain) and the zone of annual net ablation (mass loss) (Patterson, 2001). The position of the ELA is controlled by annual climate based on spatial variations in snow accumulation and mass loss through the surface energy balance. Simplified, the change in the ELA can be attributed to winter precipitation and summer temperature changes (Leonard, 1989; Ohmura et al., 1992; Porter, 1977). Changes in the ELA position through time represent changes in snow accumulation and temperature. By reconstructing the ELAs of pre-existing glaciers and comparing them with modern ELAs, aspects of the former climate can be inferred.

The ELAs for the modern and pre-existing glaciers on the east and north flanks of the Three Sisters volcanoes and the north flank of Broken Top mountain were calculated using both the accumulation area ratio (AAR) (Meier and Post, 1962) and the balance ratio methods (BR) (Furbish and Andrews, 1984). Typical AAR values for modern glaciers in a steady-state condition range from 0.5 to 0.8 (Meier and Post, 1962). Following previous work in Oregon by Scott (1977), Carver (1972), and Bevis (1995), I used an AAR value of $0.65 \pm 0.1$ to determine present and past ELAs. The BR method with a net-balance ratio of 2 , which is representative of maritime midlatitude glaciers (Furbish and Andrews, 1984), was implemented. Both the AAR and 
BR methods account for the area of the glacier residing in the ablation and accumulation zone, but the BR method goes a step further and better accounts for the distribution of glacier area with altitude. The BR method has been proven most useful for glaciers that have a "complex" shape (Benn and Gemmell, 1997; Furbish and Andrews, 1984). Because most of the glaciers at Three Sisters and Broken Top have "complex" geometries that resemble ice cap type glaciers, the BR method was viewed as a better tool in determining the ELA of the glaciers, and its values were utilized in this study. Differences in elevation between the ELAs estimated with the AAR and BR methods averaged $80 \mathrm{~m}$ with the AAR consistently predicting lower ELAs.

Using the BR method (Furbish and Andrews, 1984), the glaciers' ELAs were calculated,

$$
\frac{d b_{n b} / d z}{d b_{n c} / d z}=\frac{z_{c} A_{c}}{z_{b} A_{b}}
$$

where $d b_{n b} / d z$ is the net mass-balance gradient in the ablation zone $\left(y^{-1}\right)$, $\mathrm{db}_{\mathrm{nc}} / \mathrm{dz}$ is the net mass-balance gradient in the accumulation zone $\left(\mathrm{yr}^{-1}\right), \mathrm{z}_{\mathrm{c}}$ is the areaweighted mean altitude of the ablation zone $(\mathrm{m}), \mathrm{z}_{\mathrm{b}}$ is the area-weighted mean altitude of the accumulation zone (m), $A_{c}$ is the area of the accumulation zone $\left(\mathrm{m}^{2}\right)$ and $A_{b}$ is the area of the ablation zone $\left(\mathrm{m}^{2}\right)$. For temperate glaciers, the left hand side of equation (1) is approximately 2 (Furbish and Andrews, 1984). To determine the ELA of any given glacier, one needs to know the area distribution with elevation. For the right hand side of equation (1), one begins by assuming that the ELA is the mean 


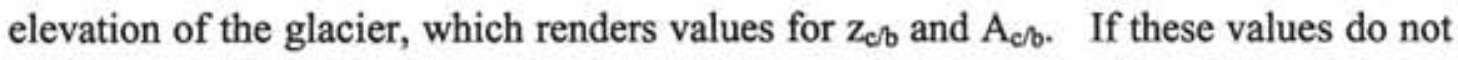
satisfy equation (1), then a new ELA is chosen and tested. One continues this trial and error process until the right hand side of equation (1) equals the left (i.e. 2). I used a computer spreadsheet developed by Benn and Gemmell (1997), which automated this process through a series of iterations. To determine the area distribution with elevation for both the BR and AAR methods, the area of the glaciers were broken up into $60 \mathrm{~m}$ elevation segments (Figure 30 - Figure 31 ). To find the ELA using the AAR method, a cumulative area plot versus elevation was constructed for each of the glaciers and, using an AAR value of $0.65 \pm 0.1$, the ELAs of the glaciers were determined. 

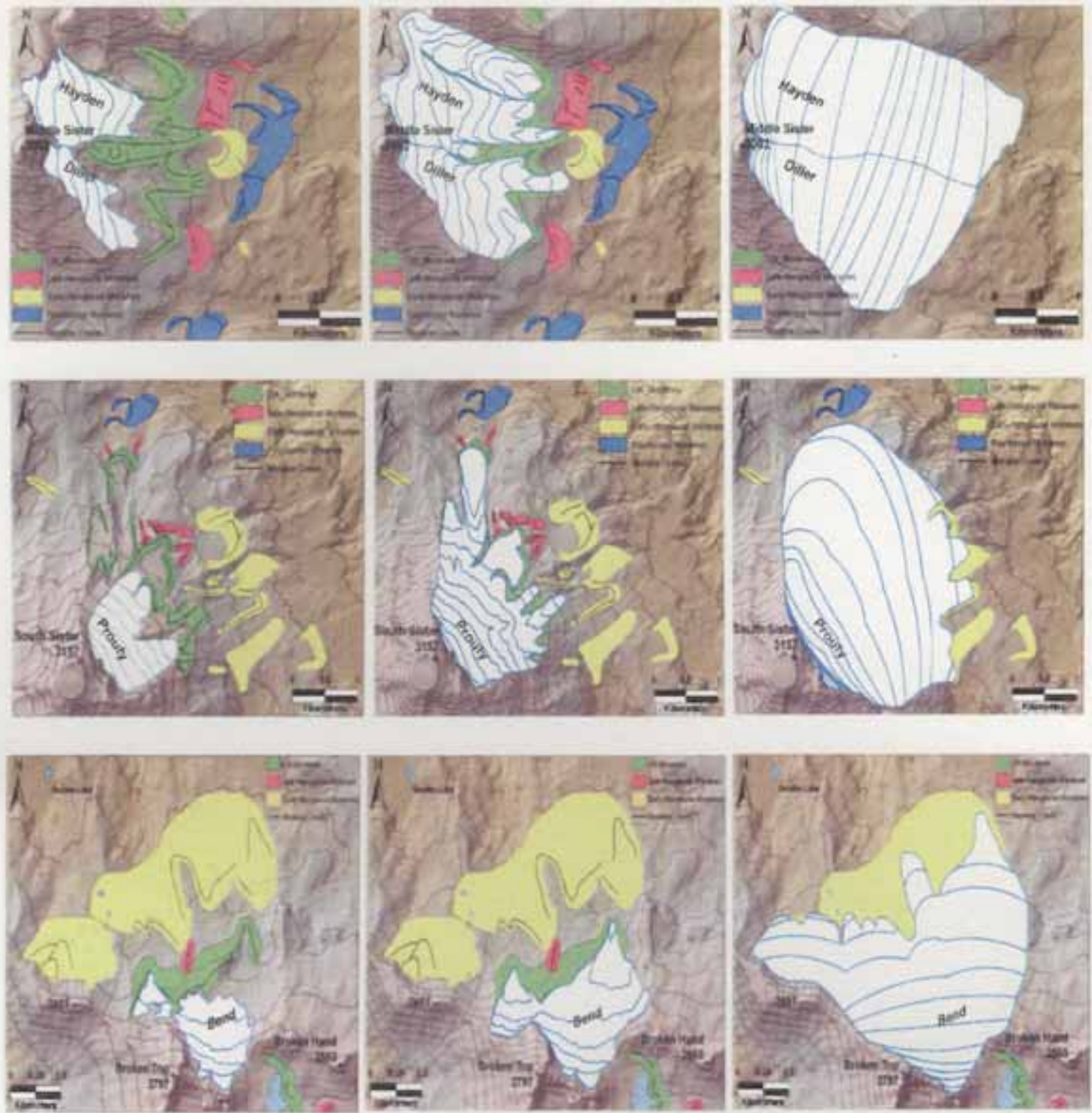

Figure 30: Shape profile used to calculate the area for modern, Little Ice Age, and EarlyNeoglacial at Diller and Hayden glaciers (top), Prouty glacier (middle), and Bend glacier (bottom). 

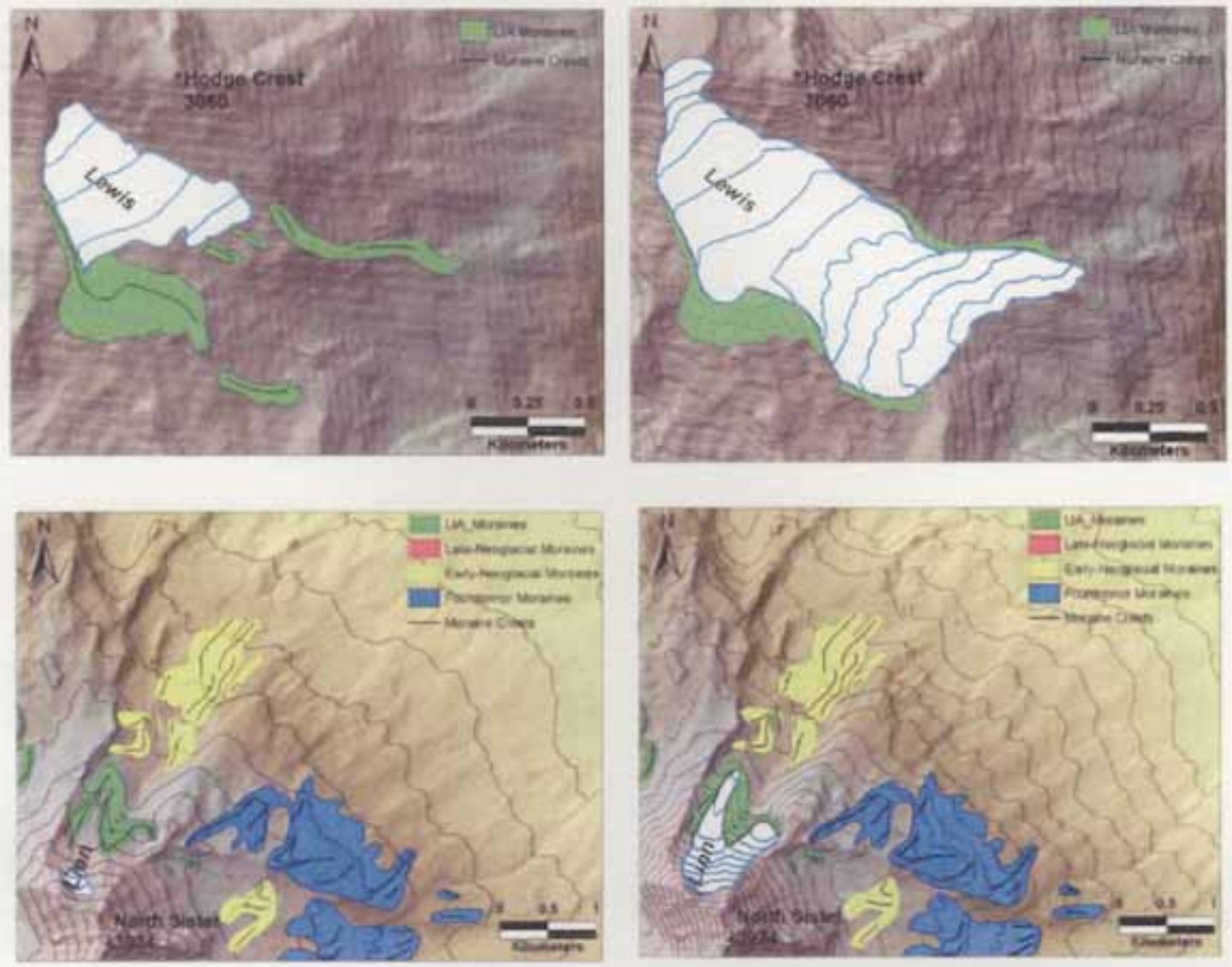

Figure 31: Shape profile used to calculate the area for modern and Little Ice Age at Lewis glacier (top) and Linn glacier (bottom).

The modern glaciers' areas were mapped using black and white aerial photographs taken during the summer of 1995 (GEO, 2005). The reconstructed glaciers for the LIA, Early-Neoglacial, and the Fountonnor extents were mapped using 7.5 minute topographic maps. The Late-Neoglacial glaciers were not reconstructed because the moraines were so few. To determine the glacier contours, 1 used modern contours from the topographic maps for both the present and LIA glaciers. I used existing bedrock elevations for the paleo-contour topography of the Early-Neoglacial and Fountonnor glaciers. This method constructs a zero thickness glacier. While a 
more realistic geometry could be constructed, I felt that the relatively steep and uniform slope of the volcano flanks did not warrant a more realistic reconstruction. Although this approach results in estimated ELAs that are likely $\sim 100 \mathrm{~m}$ too low, it is sufficient because my interest here is ELA change, not absolute ELA.

The results for the balance ratio and accumulation area ratio methods are shown in Table 3 and Table 4. The average ELA increased $40-200 \mathrm{~m}$ from the LIA to present for all the glaciers. Since the Early-Neoglacial and Fountonnor glaciations, the ELA has increased significantly. From the Early-Neoglacial to the present, the ELAs appear to have increased $130 \mathrm{~m}$ at South Sister and $300 \mathrm{~m}$ at Broken Top. From the Fountonnor glaciation, the ELAs have increased $290-320 \mathrm{~m}$ at Middle Sister. These changes in the ELAs could indicate a major shift in climate over the last 10,000 years.

Table 3: Equilibrium line altitudes (BR method) for the glaciers at Three Sisters and Broken Top during the modern, Little Ice Age, Early-Neoglacial, and Fountonnor glacial periods.

\begin{tabular}{|c|c|c|c|c|c|c|c|}
\hline \multicolumn{2}{|l|}{ Modern } & \multicolumn{2}{|c|}{ Little Ice Age } & \multicolumn{2}{|c|}{ Early-Neoglacial } & \multicolumn{2}{|c|}{ Fountonnor } \\
\hline Glacier & $\begin{array}{c}\text { ELA } \\
(\mathrm{m}) \\
\end{array}$ & Glacier & $\begin{array}{c}\text { ELA } \\
(m)\end{array}$ & Glacier & $\begin{array}{c}\text { ELA } \\
(\mathrm{m})\end{array}$ & Glacier & $\begin{array}{c}\text { ELA } \\
(\mathrm{m})\end{array}$ \\
\hline Diller & 2577 & Diller & 2466 & & & Diller & 2291 \\
\hline Hayden & 2633 & Hayden & 2541 & & & Hayden & 2318 \\
\hline Bend & 2466 & Bend & 2428 & Bend & 2332 & & \\
\hline Prouty & 2667 & Prouty & 2542 & Prouty & 2362 & & \\
\hline Lewis & 2768 & Lewis & 2648 & & & & \\
\hline Linn & 2652 & Linn & 2476 & & & & \\
\hline \multicolumn{2}{|c|}{ Average $(m)=2627$} & & 2545 & & 2347 & & 2305 \\
\hline \multicolumn{2}{|c|}{ Standard Deviation $=101$} & & 78 & & 21 & & 19 \\
\hline
\end{tabular}


Table 4: Equilibrium line altitudes (AAR method) for the glaciers at Three Sisters and Broken Top during the modern, Little Ice Age, Early-Neoglacial, and Fountonnor glacial periods

\begin{tabular}{|c|c|c|c|c|c|c|c|}
\hline \multirow{2}{*}{$\begin{array}{l}\text { Modern } \\
\text { Glacier } \\
\end{array}$} & \multicolumn{3}{|c|}{ Little Ice Age } & \multicolumn{2}{|c|}{ Early-Neoglacial } & \multicolumn{2}{|c|}{ Fountonnor } \\
\hline & $\begin{array}{l}\text { ELA } \\
(m)\end{array}$ & Glacier & $\begin{array}{c}\text { ELA } \\
(m)\end{array}$ & Glacier & $\begin{array}{c}\text { ELA } \\
(m)\end{array}$ & Glacier & $\begin{array}{c}\text { ELA } \\
(m)\end{array}$ \\
\hline Diller & $2487 \pm 30$ & Diller & $2363 \pm 35$ & & & Diller & $2188 \pm 55$ \\
\hline Hayden & $2551 \pm 40$ & Hayden & $2452 \pm 60$ & & & Hayden & $2248 \pm 110$ \\
\hline Bend & $2380 \pm 20$ & Bend & $2342 \pm 20$ & Bend & $2298 \pm 25$ & & \\
\hline Prouty & $2579 \pm 30$ & Prouty & $2437 \pm 35$ & Prouty & $2272 \pm 30$ & & \\
\hline Lewis & $2687 \pm 20$ & Lewis & $2566 \pm 70$ & & & & \\
\hline Linn & $2573 \pm 10$ & Linn & $2365 \pm 30$ & & & & \\
\hline \multicolumn{2}{|c|}{ Average $(\mathrm{m})=2543 \pm 30$} & & $2452 \pm 40$ & & $2285 \pm 30$ & & $2218 \pm 80$ \\
\hline Standard Deviation $=$ & 103 & & 84 & & 18 & & 42 \\
\hline
\end{tabular}

To determine the paleoclimate necessary to maintain the lowered ELAs for the Little Ice Age, Early-Neoglacial, and Fountonnor glaciers, I followed the methods described by Leonard (1989). By plotting the highest monthly mean accumulation ( $\mathrm{cm}$ water equivalent (weq.)) against mean summer temperatures $\left({ }^{\circ} \mathrm{C}\right)$ (June - August) at the equilibrium line of 32 modern glaciers (Figure 32), a relationship between summer temperature and winter accumulation is defined for modern climates (Leonard, 1989; Loewe, 1971; Sutherland, 1984). This relationship was mathematically defined using Kotlyakov and Krenke (1982),

$$
\begin{aligned}
& A=1.33(T+9.66)^{2.85} \\
& A=1.33(T+6.66)^{2.85}
\end{aligned}
$$

where $\mathrm{A}$ is winter accumulation (mm weq.) and $\mathrm{T}$ is the mean June-August summer temperature $\left({ }^{\circ} \mathrm{C}\right.$ ), who bound the scatter in the data with two lines (Figure 
32). The envelope between the lines defines the range of conditions for modern glaciers.

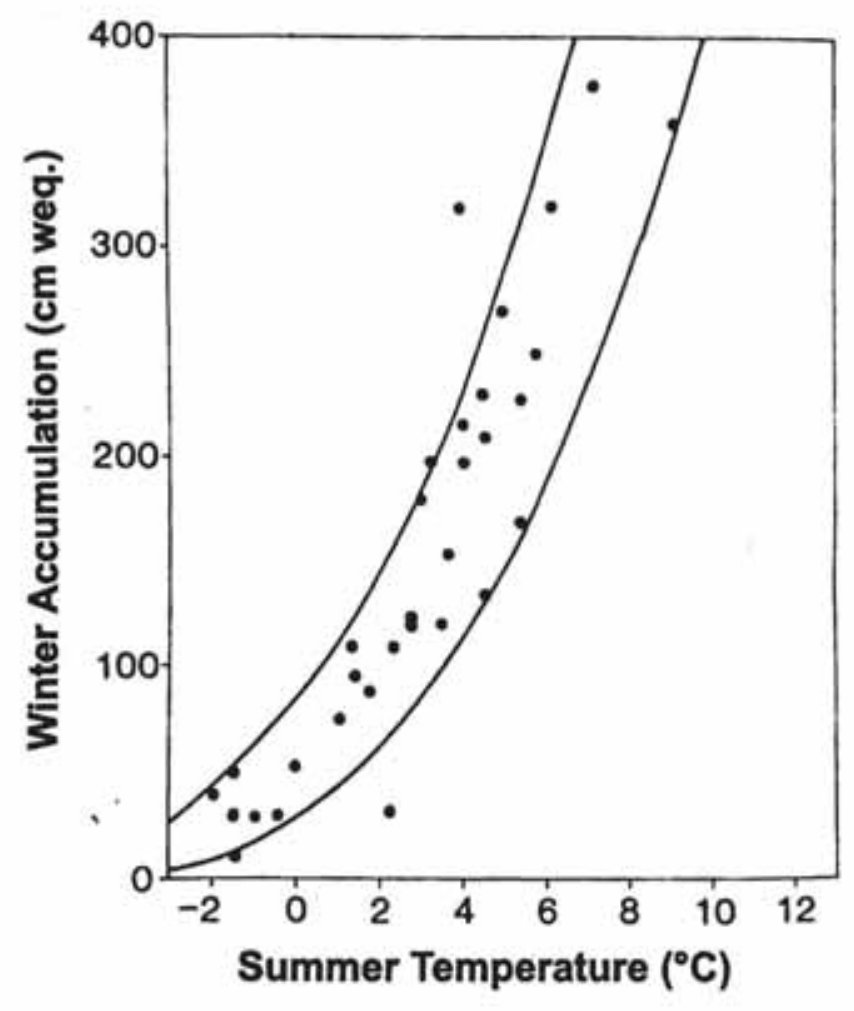

Figure 32: Winter accumulation versus mean summer temperature (June - August) at the equilibrium lines of 32 glaciers with worldwide distribution (Leonard, 1989).

Assuming that the equation (2) developed by Kotlyakov and Krenke (1982) applies to past climatic conditions, I can estimate the paleoclimate. First, the present mean summer temperature $\left({ }^{\circ} \mathrm{C}\right)$ and the highest monthly mean accumulation $(\mathrm{cm}$ weq.) at the paleo and modern ELAs were identified. To establish the temperature and accumulation at Three Sisters, linear lapse rates for mean summer temperature and highest monthly mean accumulation were derived using meteorological stations located at lower elevations. The mean summer temperature lapse rate was calculated 
using historical climate data from 1971-2001 (WRCC, 2005) from six sites in the central Cascades of Oregon between elevations of 451 and $1972 \mathrm{~m}$ (Figure 33). Because altitude and temperature have a high degree of correlation, the six sites chosen for the mean summer temperature were selected according to their elevation and distance from Three Sisters and not whether their position was east or west of the Cascade crest. The lapse rate for the summer temperature versus elevation is $0.53^{\circ} \mathrm{C} /$ $100 \mathrm{~m}$, which is close to the wet adiabatic lapse rate. The mean summer temperature regression line accounted for $96 \%$ of the variance in temperature and was statistically significant within $1 \%(\mathrm{p}=0.01)$.

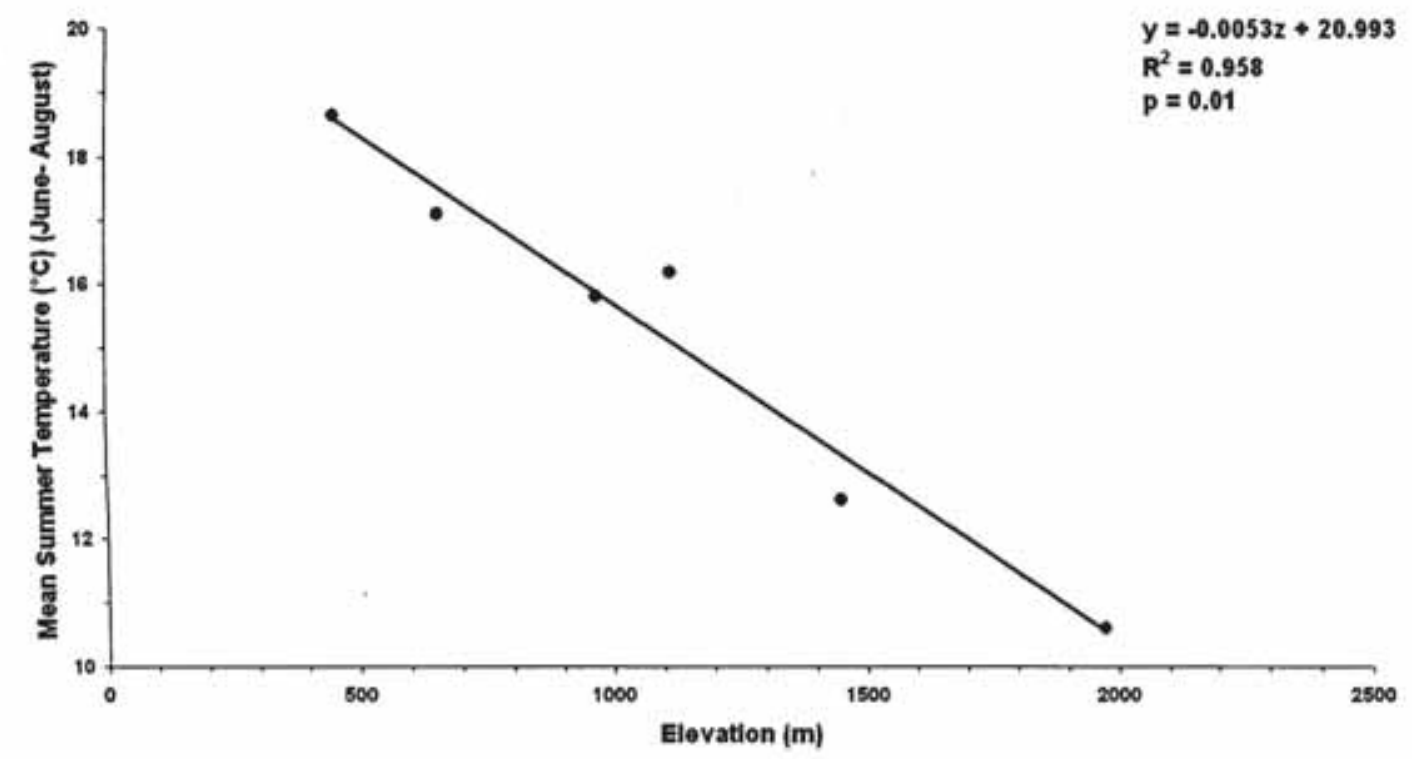

Figure 33: Linear regression line for mean summer temperature $\left({ }^{\circ} \mathrm{C}\right)$ versus elevation $(\mathrm{m})$ for six meteorological stations near the Three Sisters Volcanoes. 
Table 5: Meteorological stations used to calculate linear regression line for mean summer temperature (1971-2001) (WRCC, 2005).

\begin{tabular}{cccc} 
SNOTEL Name & $\begin{array}{c}\text { Latitude and Longitude } \\
\text { (Degrees, Minutes) }\end{array}$ & $\begin{array}{c}\text { Elevation } \\
(m)\end{array}$ & $\begin{array}{c}\text { Average Summer } \\
\text { Temperature } \\
\left({ }^{\circ} \mathrm{C}\right)\end{array}$ \\
\hline McKenzie & $44^{\circ} 11^{\prime}, 122^{\circ} 07^{\prime}$ & 451 & 18.6 \\
Belknap & $44^{\circ} 18^{\prime}, 122^{\circ} 02^{\prime}$ & 655 & 17.1 \\
Sisters & $44^{\circ} 17^{\prime}, 122^{\circ} 33^{\prime}$ & 969 & 15.8 \\
Bend & $44^{\circ} 04^{\prime},\left(122^{\circ} 17^{\prime} \& 122^{\circ} 19^{\prime}\right)$ & 1113 & 16.2 \\
Santiam & $44^{\circ} 25^{\prime}, 122^{\circ} 52^{\prime}$ & 1448 & 12.6 \\
Crater Lake & $42^{\circ} 54^{\prime}, 122^{\circ} 08^{\prime}$ & 1972 & 10.6 \\
\hline
\end{tabular}

Because winter accumulation is sensitive to small changes in local topography and aspect, and not strictly changes in altitude, meteorological stations chosen for the accumulation gradient were east of the Cascade crest and within $\sim 30 \mathrm{~km}$ of the Three Sisters and Broken Top to account for the rain shadow effect. The winter accumulation lapse rate was calculated using historical climate data from 1971-2000 (NRCS, 2005) from four SNOTEL and snow course sites between elevations of 1585 and $1951 \mathrm{~m}$ (Figure 34). The accumulation gradient for the winter accumulation versus elevation is $32.13 \mathrm{~cm} / 100 \mathrm{~m}$. For the winter accumulation, $96 \%$ of the variance was accounted for and was statistically significant within $2.5 \%(\mathrm{p}=0.025)$. 


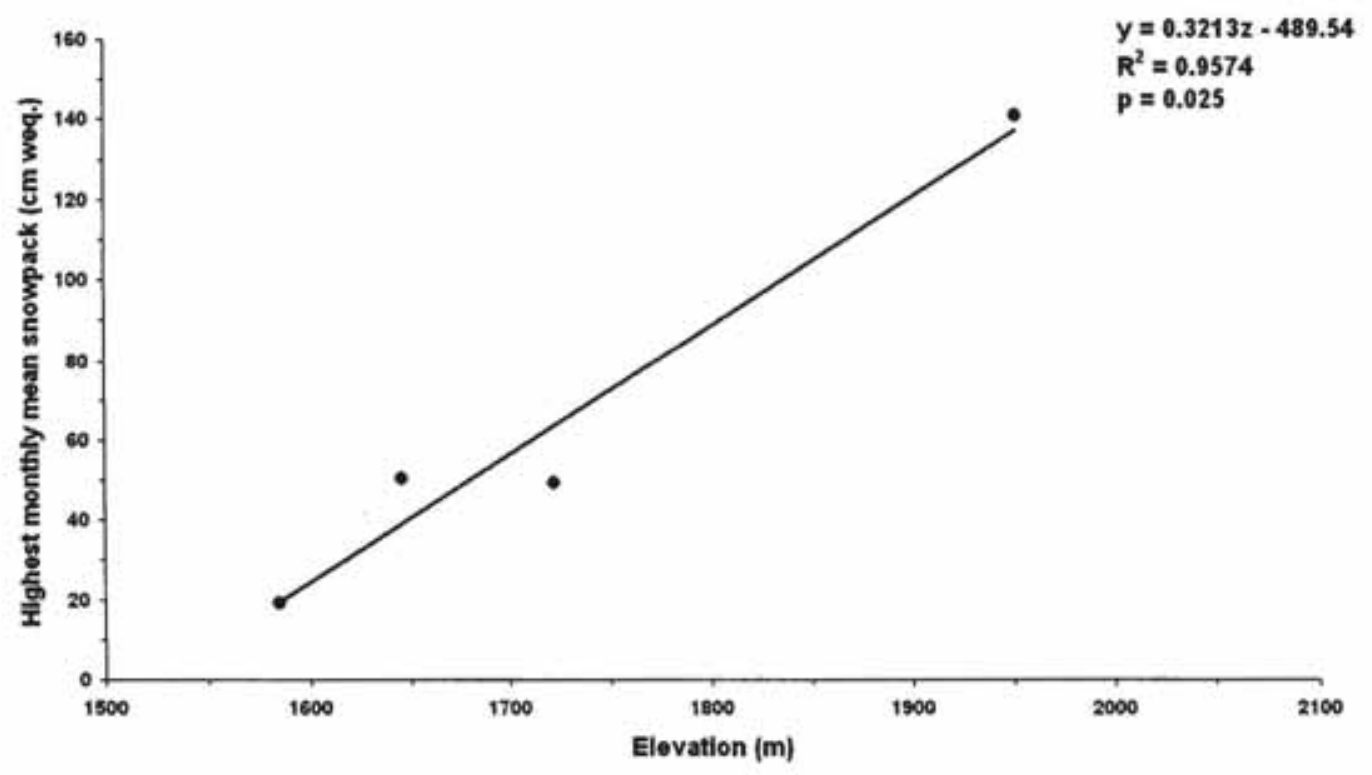

Figure 34: Linear regression line for highest monthly mean winter accumulation (cm weq.) versus elevation $(m)$ for four meteorological stations east of the Three Sisters Volcanoes.

Table 6: Meteorological stations used to calculate linear regression line for mean winter accumulation (1971-2000) (NRCS, 2005).

\begin{tabular}{cccc}
$\begin{array}{c}\text { SNOTEL or } \\
\text { Snow Course Name }\end{array}$ & $\begin{array}{c}\text { Latitude and Longitude } \\
\text { (Degrees, Minutes) }\end{array}$ & $\begin{array}{c}\text { Elevation } \\
(\mathrm{m})\end{array}$ & $\begin{array}{c}\text { Highest Monthly } \\
\text { Mean Snowpack } \\
(\mathrm{cm} \text { weq.) }\end{array}$ \\
\hline Three Creek Butte & $44^{\circ} 09^{\prime}, 121^{\circ} 38^{\prime}$ & 1585 & 19.3 \\
Tangent & $44^{\circ} 01^{\prime}, 121^{\circ} 34^{\prime}$ & 1646 & 50.6 \\
Three Creeks Meadow & $44^{\circ} 09^{\prime}, 121^{\circ} 38^{\prime}$ & 1722 & 49.2 \\
New Dutchman Flat \#3 & $44^{\circ} 00^{\prime}, 121^{\circ} 42^{\prime}$ & 1951 & 140.7 \\
\hline
\end{tabular}

Using the modern lapse rate for temperature and the accumulation gradient, the modern climate at the paleo and modern ELAs were determined (Table 7; Figure 35). For the modern glaciers at Three Sisters, the predicted climate conditions were in close agreement with Figure 32. To determine the past climates required at the ELAs, the current climate for the LIA, Early-Neoglacial and Fountonnor ELAs were plotted 
onto Figure 32 (Figure 36). These points were then adjusted for the climate required to sustain a glacier with that ELA.

Table 7: Estimated modern climate conditions at present and past glacier equilibrium lines (balance ratio).

\begin{tabular}{ccccc} 
& Glacier & ELA & Summer Temperature & Winter Accumulation \\
\hline Modern Glaciers & & $(m)$ & $\left({ }^{\circ}\right)$ & $(c)$ \\
\cline { 2 - 5 } & Diller & 2577 & 7.3 & 338 \\
& Hayden & 2633 & 7.0 & 356 \\
Bend & 2466 & 7.9 & 303 \\
& Prouty & 2667 & 6.9 & 367 \\
& Lewis & 2768 & 6.3 & 400 \\
& Linn & 2652 & 6.9 & 363
\end{tabular}

\begin{tabular}{|c|c|c|c|c|}
\hline \multirow[t]{7}{*}{ LIA Glaciers } & & $(m)$ & $\left({ }^{\circ} \mathrm{C}\right)$ & (cm weq.) \\
\hline & Diller & 2466 & 7.9 & 303 \\
\hline & Hayden & 2541 & 7.5 & 327 \\
\hline & Bend & 2428 & 8.1 & 291 \\
\hline & Prouty & 2542 & 7.5 & 327 \\
\hline & Lewis & 2648 & 7.0 & 361 \\
\hline & Linn & 2476 & 7.9 & 306 \\
\hline \multirow[t]{3}{*}{ Early-Neoglacial } & & (m) & $\left({ }^{\circ} \mathrm{C}\right)$ & (cm weq.) \\
\hline & Bend & 2332 & 8.6 & 260 \\
\hline & Prouty & 2362 & 8.5 & 269 \\
\hline \multirow[t]{3}{*}{ Fountonnor } & & (m) & $\left({ }^{\circ} \mathrm{C}\right)$ & (cm weq.) \\
\hline & Diller & 2278 & 8.9 & 247 \\
\hline & Hayden & 2298 & 8.7 & 255 \\
\hline
\end{tabular}




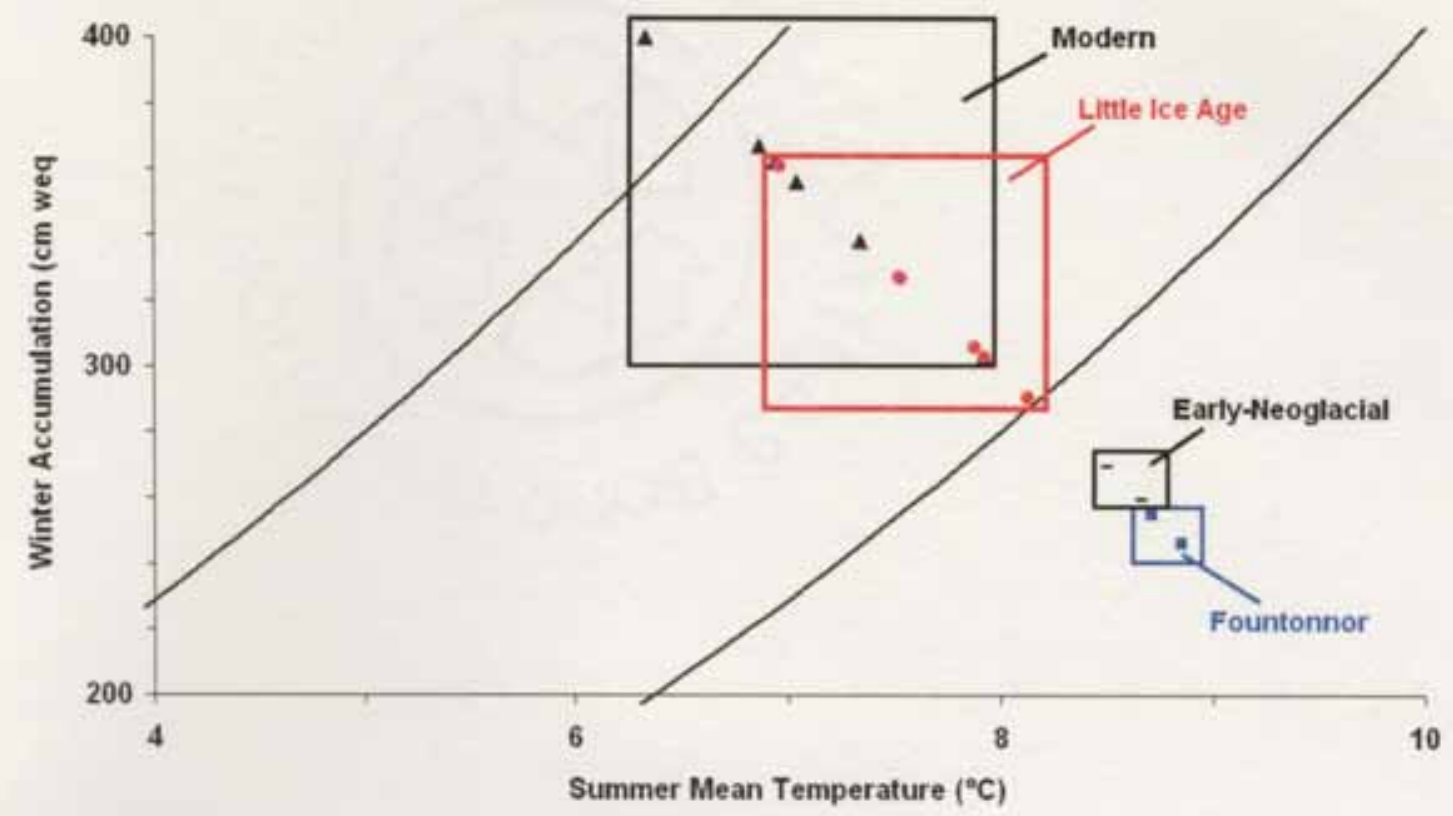

Figure 35: Estimated modern climates at present, LIA, Early-Neoglacial and Fountonnor glacier equilibrium lines (adapted from Leonard, 1989). Black lines are climate envelope defined by Kotlyakov and Krenke (1982) and illustrated in Leonard (1989). 

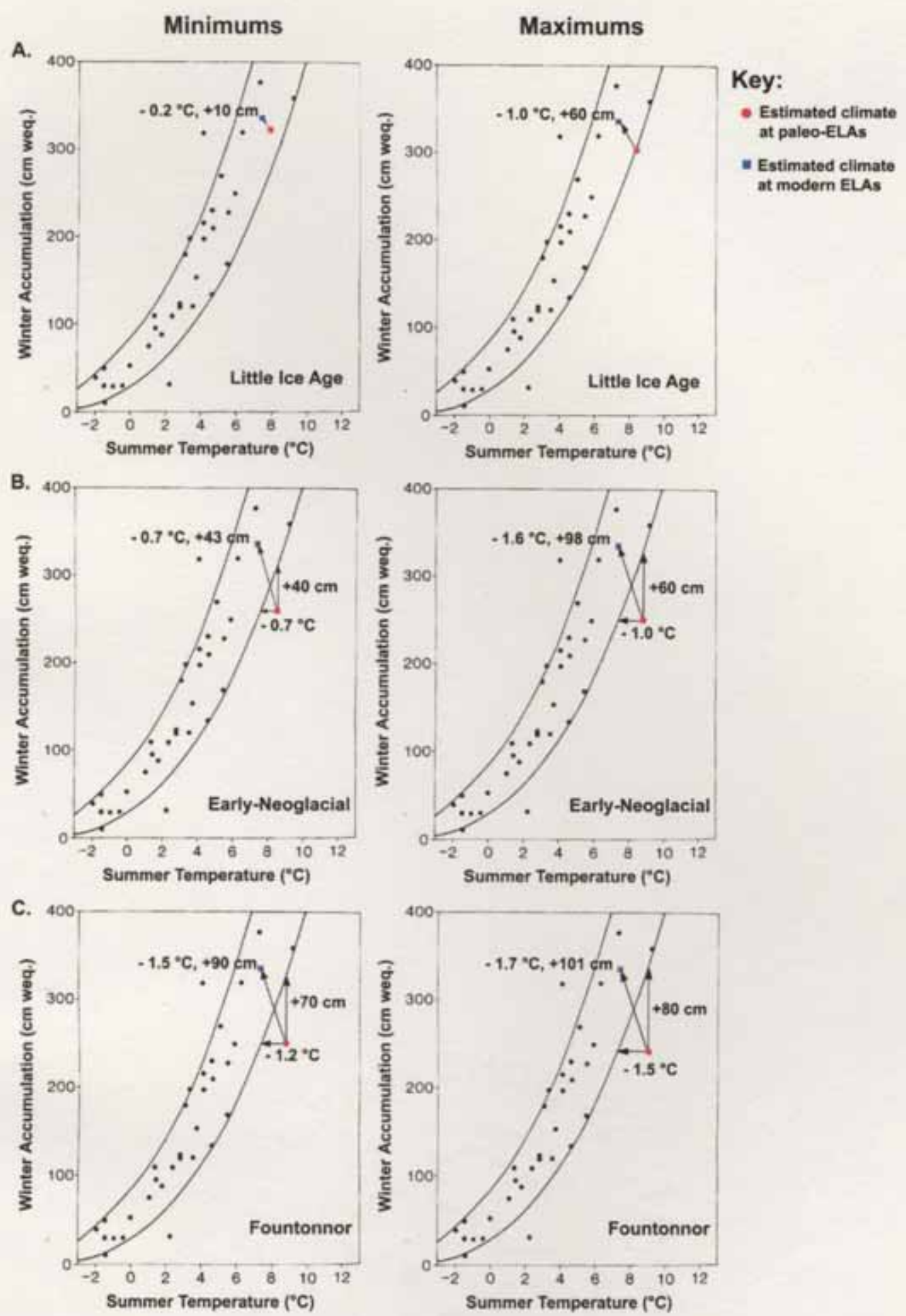

Figure 36: Winter accumulation versus mean summer temperature at the equilibrium lines of glaciers throughout the world (Leonard, 1989). Arrows and numbers indicate minimum and maximum summer temperature depressions and winter accumulation increases needed to shift the paleo-ELAs into modern glacier conditions 
The difference between the modern climate conditions at the present glaciers and those of the LIA is small. The mean summer temperature would need to decrease by $0.2-1.0^{\circ} \mathrm{C}$ and increase in winter accumulation by $10-60 \mathrm{~cm}$ weq. (Figure 36 ). Climate conditions at the Early-Neoglacial equilibrium lines would need to either decrease mean summer temperature by minimum of $0.7^{\circ} \mathrm{C}\left(0.7-1.0^{\circ} \mathrm{C}\right)$ or increase mean monthly winter accumulation by a minimum of $40 \mathrm{~cm}$ weq. $(40-60 \mathrm{~cm}$ weq.) to plot on the bottom climate curve (Figure 36). For the climate at the EarlyNeoglacial glaciers to reach a similar value as the present glaciers, mean summer temperature needs to decrease by a minimum of $0.7^{\circ} \mathrm{C}\left(0.7-1.6^{\circ} \mathrm{C}\right)$ and mean monthly winter accumulation needs to increase by a minimum of $40 \mathrm{~cm}$ weq. $(40-$ $100 \mathrm{~cm}$ weq.). For the Fountonnor glaciers to plot on the bottom of the curve, mean summer temperature needs to decrease by a minimum of $1.2^{\circ} \mathrm{C}\left(1.2-1.5^{\circ} \mathrm{C}\right)$ or increase mean monthly winter accumulation by a minimum of $70 \mathrm{~cm}$ weq. $(70-80$ cm weq.) (Figure 36). For the climate at the Fountonnor glaciers to reach a similar value as the present glaciers, a mean summer temperature needs to decrease by a minimum of $1.5^{\circ} \mathrm{C}\left(1.5-1.7^{\circ} \mathrm{C}\right)$ and mean monthly winter accumulation needs to increase by a minimum of $90 \mathrm{~cm}$ weq. $(90-100 \mathrm{~cm}$ weq. $)$. 


\section{Chapter 4: Discussion and Conclusions}

\subsection{Discussion}

The modern glaciers on the east flanks of the Three Sisters Volcanoes and on the north flank of Broken Top Mountain (Linn, Diller, Hayden, Prouty, Lewis, and Bend glaciers) are on average $\sim 0.60 \mathrm{~km}^{2}$ in area, covering a total area of $\sim 3.50 \mathrm{~km}^{2}$ (Driedger and Kennard, 1986). Maximum ice thicknesses measured with groundpenetrating radar are between $45-75 \mathrm{~m}$ yielding a total ice volume of $\sim 0.07 \mathrm{~km}^{3}$ (Driedger and Kennard, 1986). The glacier extent is bounded by 2100 and $3100 \mathrm{~m}$ elevation. The average ELA is $\sim 2627 \mathrm{~m}$ (balance ratio) or $2543 \pm 30$ (accumulation area ratio), which corresponds well with ELAs measured on the east side of Mt. Jefferson and Three-Fingered Jack $(2590 \pm 35 \mathrm{~m})$ using a similar AAR value of $0.65 \pm$ 0.1 (Scott, 1977).

Based on both lateral and terminal moraines, the LIA glaciers (Linn, Diller, Hayden, Prouty, Lewis, and Bend) primarily existed between 2200 and $3000 \mathrm{~m}$ elevation, and the average ELA for the LIA glaciers was $80 \mathrm{~m}$ (balance ratio) to $90 \mathrm{~m}$ (accumulation area ratio) lower than modern glaciers. The LIA glacial advance at Three Sisters extended 1-2 km from the glacial headwalls and the glaciers likely stayed at their maximum positions for a time sufficient to construct the large $(\sim 60 \mathrm{~m})$ and well developed end and lateral moraines. Based on the lack of Devil's Hill and Rock Mesa tephra $(\sim 2100 \pm 400$ yrs. B.P. $)$ and the lack of developed soil horizons and plant cover on the moraine slopes, the LIA advances at Three Sisters likely 
reached their maximum positions within the last $150-250$ years, which is consistent with temperature depressions recorded in tree rings from Oregon and other land based temperature data (O'Connor et al., 2001; Wiles et al., 1996). The LIA deposits at Three Sisters and Broken Top are correlative in time with LIA moraine deposits in other regions of Oregon (Carver, 1972; LaFrenz, 2001; Lillquist, 1988; Scott, 1974; Scott et al., 1990) and the western United States (Anderson and Anderson, 1981; Burrows et al., 2000; Crandell, 1969; Madsen and Currey, 1979; Miller, 1969).

The remnant Late-Neoglacial moraines are isolated to only a few localities on the Three Sisters and Broken Top mountain and are difficult to reconstruct and correlate with other advances in the western United State. The moraines could represent a still stand of the glaciers during the retreat from the Early-Neoglacial or Fountonnor moraines but confirming this is difficult. The moraines formed between $\sim 2$ and 8 ka B.P. based on the presence of Devil's Hill / Rock Mesa tephra $(\sim 2100 \pm$ 400 yrs. B.P.), the lack of Mazama ash (7.7 ka yrs B.P.), and the small degree of morainal weathering and vegetation cover.

From lateral and end moraines at South Sister and Broken Top, the EarlyNeoglacial glaciers (Prouty and Bend) primarily existed between 2100 and $3000 \mathrm{~m}$ elevation. The average ELA from the two glaciers was $280 \mathrm{~m}$ (balance ratio) to $260 \mathrm{~m}$ (accumulation area ratio) lower than modern glaciers. The Early-Neoglacial glaciers were more extensive than the both the LIA and Late-Neoglacial glaciations with glaciers extending $2-3 \mathrm{~km}$ from the glacial headwalls. The Early-Neoglacial stand at Three Sisters occurred during the mid Holocene ( $2.5-8.0$ ka. B.P.) based on the 
presence of Devil's Hill and/or Rock Mesa tephra $(\sim 2100 \pm 400$ yrs. B.P. $)$ and the lack of Mazama ash (7,700 yrs B.P.) on the moraine slopes (Dethier, 1980a, b). Locally, the Early-Neoglacial deposits are similar to the Neoglacial I deposits at Mt. McLoughlin (Carver, 1972). Both deposits lie stratigraphically above Mazama tephra, are covered with large amounts of lichen and tree cover, do not have much soil development, and are $<3 \mathrm{~km}$ from the termini of modern glaciers. In additions, both the Early-Neoglacial and Neoglacial 1 deposits at Mt. McLoughlin had ELAs that were 200-300 m lower than modern glaciers.

Evidence from lateral and end moraines at Middle Sister suggests that the reconstructed Fountonnor glaciers (Diller and Hayden) extended 3-4 km from the glacial headwalls. The Fountonnor stand was pre-Mazama ( 7500 yrs. B.P.) and based on the incorporation of the Mazama tephra in the soil deposits and the amount of weathering of the Fountonnor moraines, the stand may have been within the last 10,000-12,000 years. Locally, the Fountonnor moraines are stratigraphically and geomorphically similar to the Canyon Creek drift of the Cabot Creek advance at Mt. Jefferson (Scott, 1974) and the Zephyr Lake drift in the Mountain Lakes Wilderness (Carver, 1972). Both the Canyon Creek and Zephyr Lake drifts are covered with Mazama ash and both sets of moraines have medium soil development $(15-45 \mathrm{~cm})$, similar to the Fountonnor deposits at Three Sisters. However, the Fountonnor glaciers' ELAs were only $320 \mathrm{~m}$ (both balance and accumulation area ratio) lower than current glaciers while the Canyon Creek and Zephyr Lake glacier's ELA dropped $700-750 \mathrm{~m}$. The difference in ELA may result from differences in topography causing 
variations in precipitation and temperature between the sites, but because all three sites are within $\sim 150 \mathrm{~km}$ of each other and have comparable elevations $( \pm 500 \mathrm{~m})$, it is unlikely that drastic changes in temperature occurred. Also, large and sustained differences in snowfall are unlikely. I infer that the Fountonnor stand was slightly younger and less extensive than the Canyon Creek and Zephyr Lake drifts and that these drifts may correlate with the apparent glacial deposits that exist further downslope of the Fountonnor moraines. If correct, the Fountonnor stand would be post Younger Dryas, and correlate with advances found at Mt. Rainier $(10.4 \pm 0.5 \mathrm{ka}$ B.P.) and the Wallowa Mountains (10.2 \pm 0.5 ka B.P.) (Heine, 1997 ; Licciardi et al., $2004)$ or the Younger Dryas advances found in British Columbia (11.5 \pm 0.3 ka B.P.), the Enchantment Lakes Wilderness (>11.3 ka B.P.), and the San Bernadino Mountains (12.5 \pm 0.5 ka B.P.) (Bilderback, 2004; Owen et al., 2003; Reasoner et al., 1994).

Climate reconstructions show that to maintain the LIA ELA $(2630 \mathrm{~m})$ the summer temperature would need to decrease by $0.2-1.0^{\circ} \mathrm{C}$ and/or the mean winter precipitation would need to increase by $10-60 \mathrm{~cm}$ weq. From land based temperature data, global temperatures since 1850 (i.e. LIA) have increased by $0.5^{\circ} \mathrm{C}$ (Jones and Bradley, 1992), which closely resembles the changes necessary for the ELA depression at Three Sisters. Locally, tree ring data collected in the Pacific Northwest (Figure 37) indicate summer air temperatures have increased by $\sim 0.6^{\circ} \mathrm{C}$, while annual precipitation is approximately the same ( $<5 \mathrm{~cm}$ difference) (Garfin and Hughes, 1996; Wiles et al., 1996). From both the tree ring data and the work by Jones 
and Bradley (1992), it appears that the LIA ELA depression at Three Sisters may have been due primarily to a decrease in temperature and rather than increased snow fall.

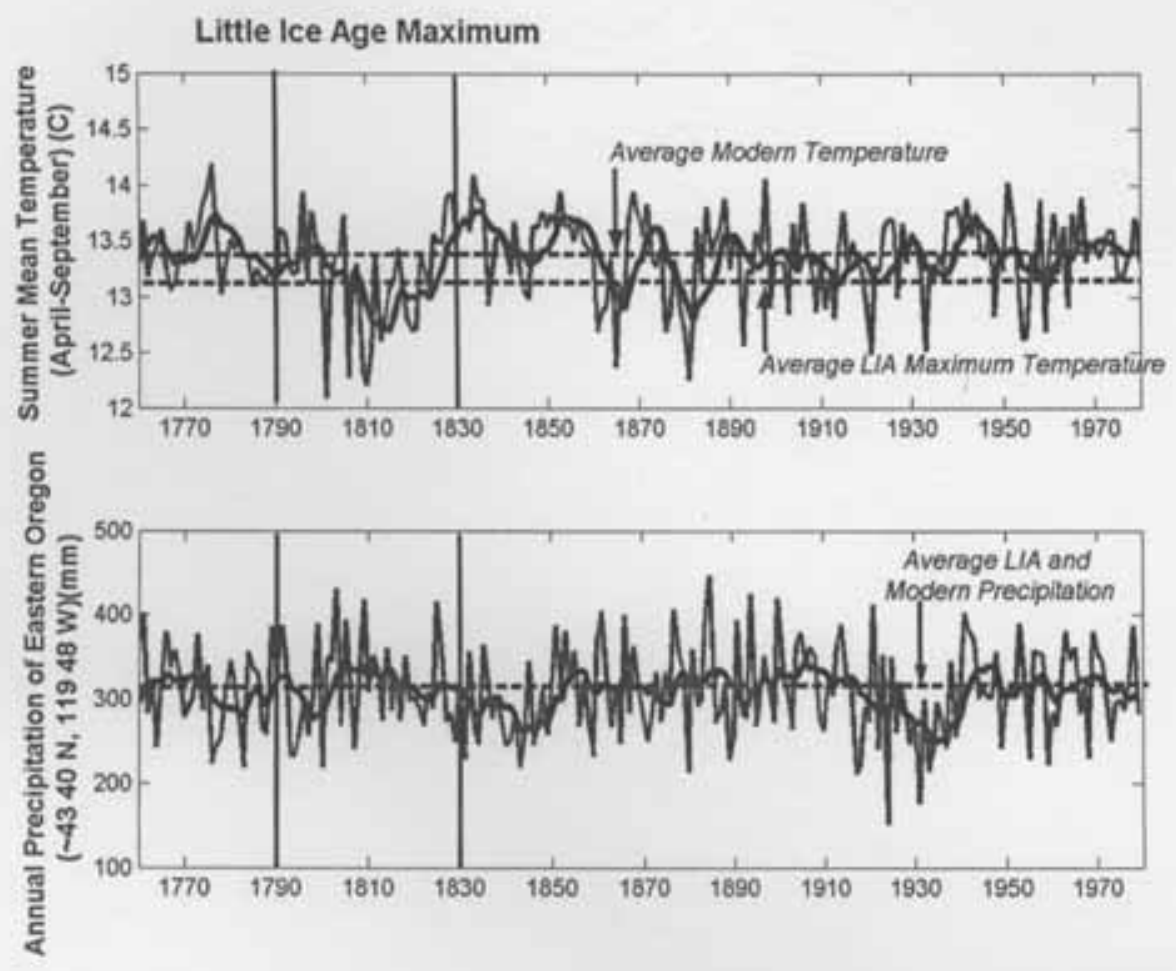

Figure 37: Reconstructed temperature and precipitation data from tree ring-widths and latewood density chronologies for the Pacific Northwest (1760-1980). Bold lines are 7-year moving average of temperature and precipitation data. The upper graph is the reconstructed mean temperature $\left({ }^{\circ} \mathrm{C}\right.$ ) from April to September (Wiles et al., 1996). The lower graph is the reconstructed annual precipitation $(\mathrm{mm})$ for several sites near $43^{\circ} 40^{\prime} \mathrm{N}, 19^{\circ} 48^{\prime}$ W in Eastern Oregon (Garfin and Hughes, 1996).

For the Early-Neoglacial and Fountonnor stands a temperature decrease of 0.7 $-1.6^{\circ} \mathrm{C}$ and/or a winter precipitation increase of $40-100 \mathrm{~cm}$ weq. would have been necessary for the estimated ELA depression of the Early-Neoglacial glaciers $(\sim 280$ $\mathrm{m})$, while the Fountonnor glaciers $(\sim 320 \mathrm{~m})$ would have required a temperature decrease of $1.5-1.7^{\circ} \mathrm{C}$ and a winter precipitation increase of $90-100 \mathrm{~cm}$ weq. 
Evidence of cooling during the early Holocene and latest Pleistocene has come from a high-resolution record of sea surface temperature (SST) reconstructed from alkenones collected off the northern coast of California (ODP Site 1019). From the SST information at Site 1019, it is apparent that a cooling interval, similar in time to the Younger Dryas cooling, affected the eastern Pacific sea surface temperatures dropping them by as much as $4^{\circ} \mathrm{C}$ from modern levels (Figure 38) (Barron et al., 2003). Following this Younger Dryas-like cooling event, there was a brief warming period at $\sim 11.3 \mathrm{ka}$ B.P. followed by another cooling period $\left(\sim 1.5^{\circ} \mathrm{C}\right.$ from modern $)$ at $\sim 11.0 \mathrm{ka}$ B.P. These warming and cooling events during the early Holocene and late Pleistocene accord with a speleothem record collected at the Oregon Caves National Monument (Figure 39) (Vacco, 2003). If the glacial events at Three Sisters are correlative with the temperature data from the SST and speleothem records, then the apparent moraines downslope of the Fountonnor moraines may correlate with the more distinct and much cooler $\left(\sim 4^{\circ} \mathrm{C}\right)$ Younger Dryas cooling while the Fountonnor stand, which was much smaller and associated with a decreased in temperature by only $1.5-1.7^{\circ} \mathrm{C}$, would resemble the post-Younger Dryas cooling $\left(\sim 1.5^{\circ} \mathrm{C}\right)$ at around 11.0 ka B.P (Figure 40). The Early-Neoglacial stand at the Three Sisters was after $\sim 7.7$ ka yrs. B.P. based on the lack of Mazama ash on the moraines. From the SST information at Site 1019, the Early-Neoglacial most likely occurred between 4500 6500 yrs. B.P where the temperature depression recorded from the alkenones $\left(\sim 1.5^{\circ} \mathrm{C}\right)$ was similar to the $0.7-1.6^{\circ} \mathrm{C}$ decrease at Three Sisters. 

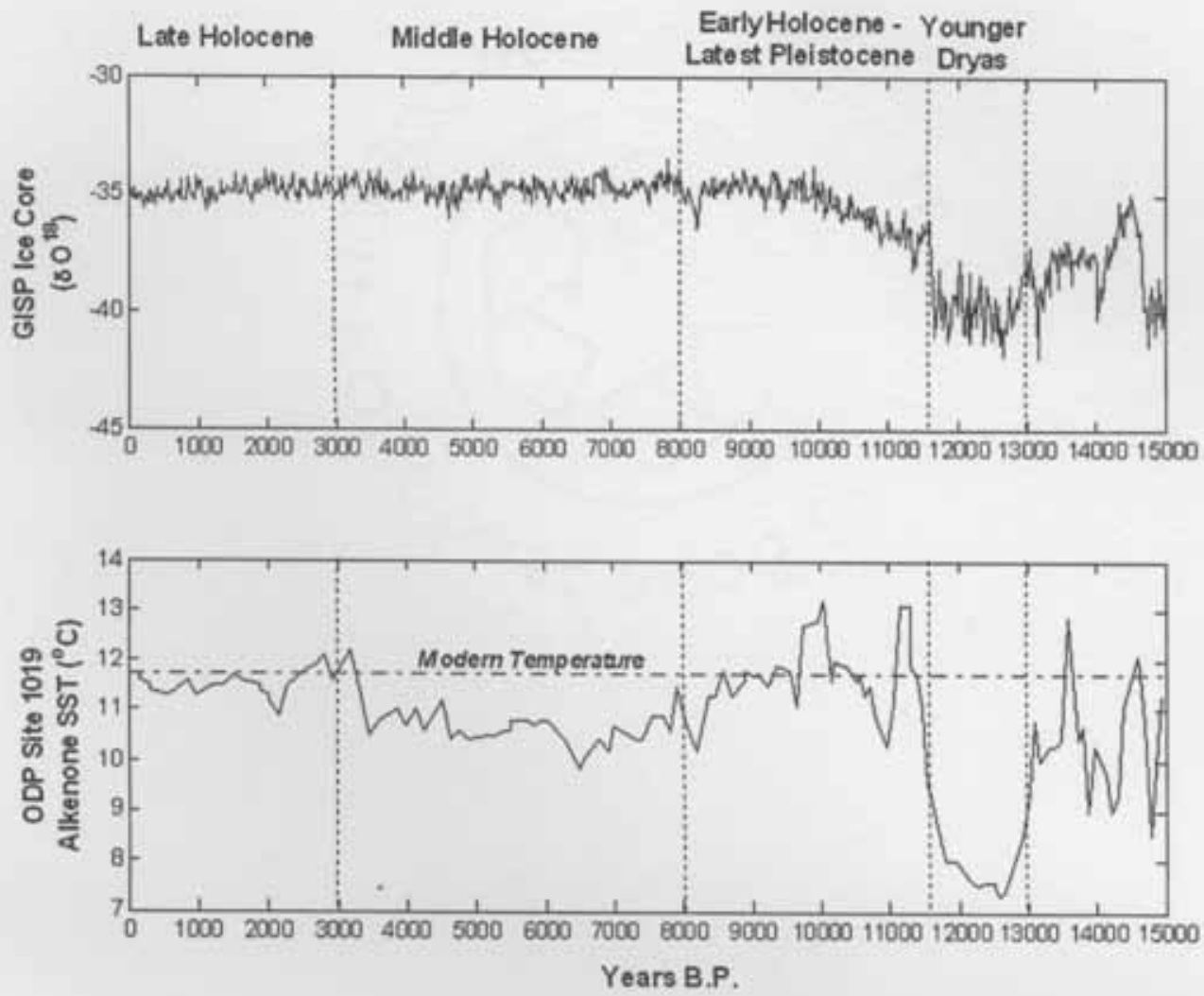

Figure 38: Reconstructed oxygen isotope curve from the GISP2 Ice Core record (top) (Stuiver and Grootes, 2000) and the reconstructed sea surface temperature (SST) from alkenones at Site 1019 in the Pacific Ocean just off the northern coast of California and southern coast of Oregon (bottom) (Barron et al., 2003). 


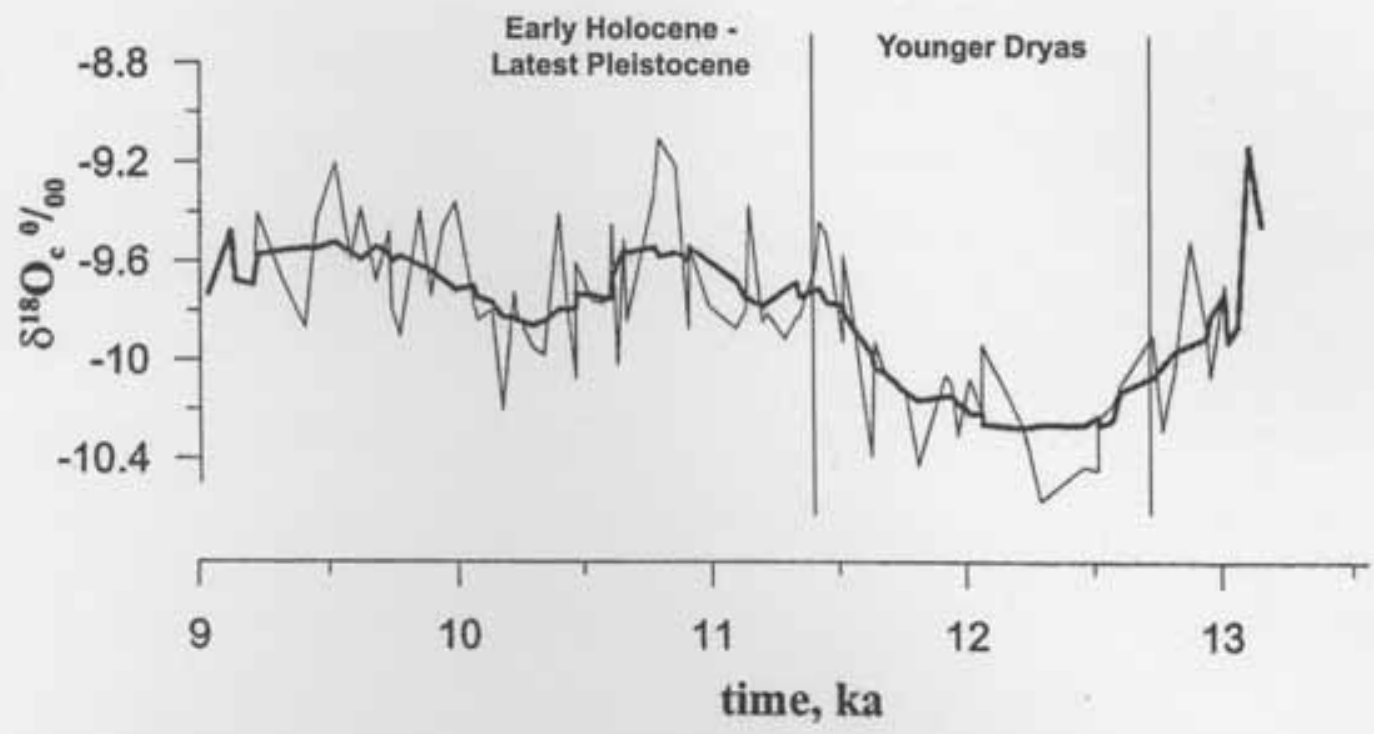

Figure 39: Oxygen-18 record from a stalagmite record (OCNM8-02A) collected from Oregon Caves National Monument in southwestern Oregon (Vacco, 2003). The bold line represents a 10point running mean of the oxygen-18 data. It is apparent that a large cooling event took place during the Younger Dryas time intervals $(13.0-12.0 \mathrm{ka}$ B.P.) followed by a brief warming (12.0 10.8 ka B.P.) and cooling $(10.8-10.0$ ka B.P.) event.

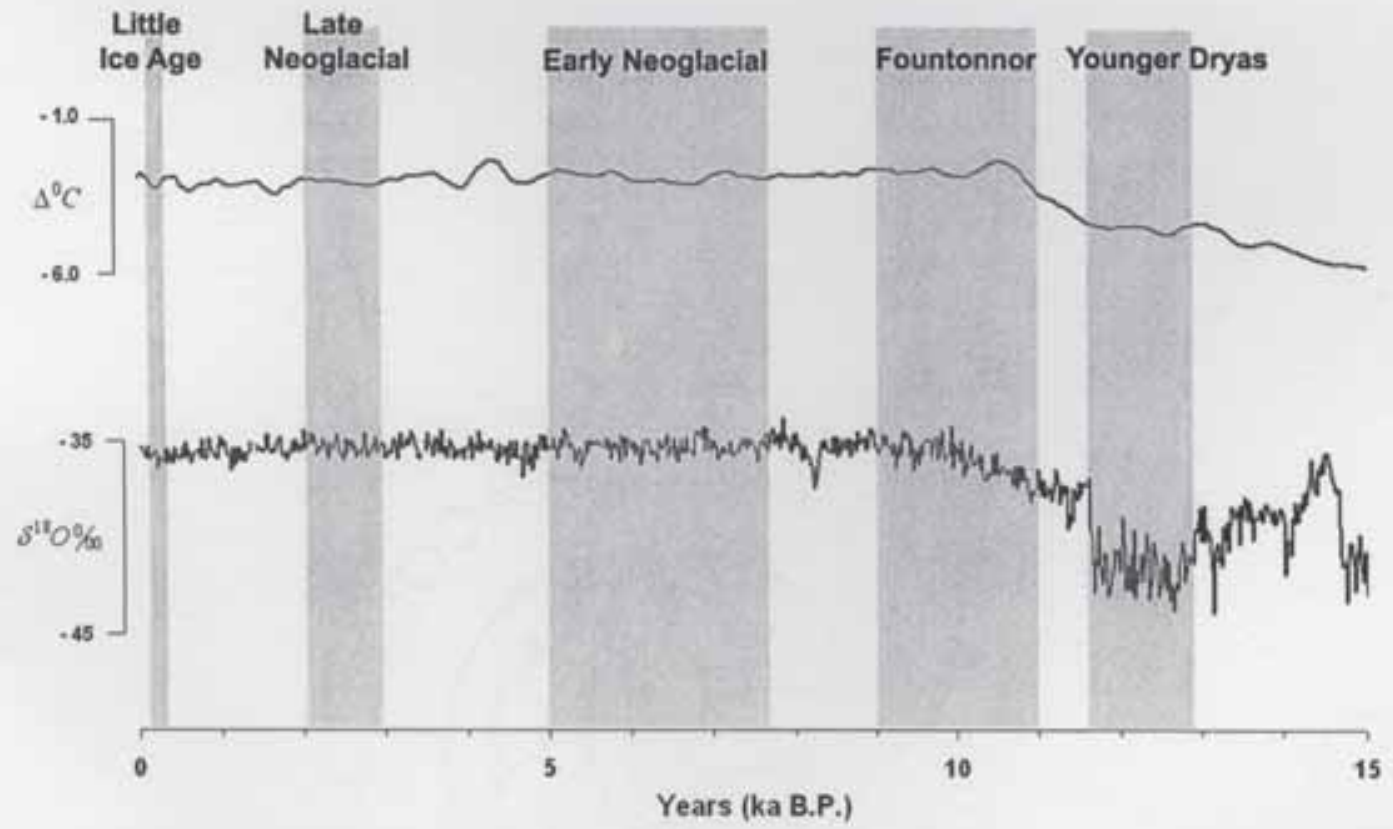

Figure 40: Comparison of glacial advances and stands in the Three Sisters Wilderness with inferred global air temperatures based on the oxygen isotope curve from the Greenland Ice Sheet Project 2 (GISP2) ice core (Stuiver and Grootes, 2000) and the deuterium curve from the Lake Vostok ice core from Antarctica (Lorius et al., 1985; Sowers et al., 1993). 
Other evidence of both the Younger Dryas and post-Younger Dryas warming has come from pollen records collected in lake cores throughout western Oregon. Between 11.0 and 12.4 ka B.P. there was an increase in haploxylon Pinus pollen at Little Lake in the Oregon Coast Range, which would imply cooler winters and drier summers. Additionally, the expansion of $P$. monticola and decline of Pseudotsuga indicate cooler winters and more snowfall (Grigg and Whitlock, 1998; Worona and Whitlock, 1995). Following the cooling interval, the pollen record suggests that the vegetation was similar to modern forests and that there was a decrease in precipitation and warmer, drier summers between 10.2 and 11.0 ka B.P. Why the post-Younger Dryas cooling interval ( 11 ka B.P.) found by Vacco (2003) and Barron et al. (2003) was not seen in the pollen records, is unknown. Perhaps the event was short lived and the vegetation in Oregon did not have time to equilibrate. However, the glacial advances at the Wallowa Mountains (10.2 \pm 0.6 ka B.P.) (Licciardi et al., 2004) and Mt. Rainier (10.4 \pm 0.5 ka B.P.) (Heine, 1997) suggest that a post-Younger Dryas advance did take place in the western United States.

\subsection{Conclusions}

At least four post Last Glacial Maximum glacial advances/stands marked by end and lateral moraines occurred on the eastern flanks of the Three Sisters Volcanoes and the northern flanks of Broken Top mountain in the central Cascade Mountains of Oregon. The youngest of these was the LIA glaciation, which reached its maximum $150-200$ yrs. B.P. and is well defined by the $60 \mathrm{~m}$ high moraines adjacent to the 
modern glaciers. Less than $100 \mathrm{~m}$ downslope from the LIA moraines, a second set of sparsely vegetated lateral moraines mark a Late-Neoglacial stand. These LateNeoglacial moraines predate the local rhyolitic eruptions from the Devil's Hill and Rock Mesa volcanic chain on South Sister $(2.1 \pm 0.4$ ka B.P. $)$ and post date the Mount Mazama eruption ( 7.7 ka B.P.). The moraines were likely deposited between $2-3$ ka B.P. based on moraine weathering and vegetation cover. Beyond the LateNeoglacial moraines, a third set of moraines is present $200-600 \mathrm{~m}$ downslope of the modern glacier termini. These moraines record the Early-Neoglacial stand of the glaciers and also predate the Devil's Hill and Rock Mesa eruptions and postdate the Mazama eruption. From SST temperature data (Barron et al., 2003) and a speleothem record (Vacco, 2003), it is most likely that this advance occurred between 4.5 and 6.5 ka B.P. A fourth set of moraines, which I have termed the Fountonnor moraines, are 500-900 $\mathrm{m}$ downslope of the modern glacier termini and pre-date $\sim 7,700$ yrs. B.P. based on the Mazama ash deposit on their slopes. These moraines may be latest Pleistocene or early Holocene in age inferred from their weathering characteristics, flat crests, vegetation cover, and soil development. An apparent fifth and possible sixth set of moraines exists $700-1500 \mathrm{~m}$ downslope of the modern glacier termini. The moraines are overlain by Mazama ash and are older than the Fountonnor moraines due to their heavier vegetation cover, severe weathering, and flattened moraine profiles.

From the paleoclimate signatures established from the glacial deposits at the Three Sisters and Broken Top, the average summer temperature would have cooled by $1.5-1.7^{\circ} \mathrm{C}$ and the winter precipitation would have had to rise by $90-100 \mathrm{~cm}$ weq. 
during the Fountonnor stand. These changes in temperature during the Fountonnor stand would suggest that during the latest Pleistocene and early Holocene $(\sim 10-11.5$ ka B.P.) the temperature was cooler by $1-2^{\circ} \mathrm{C}$ in the summer and wetter by $50-150 \mathrm{~cm}$ weq. in the winter. This accords with sea surface temperatures records from California (Barron et al., 2003) and similar glacial advances in the Wallowa Mountains (10.2 \pm 0.6 ka B.P.) (Licciardi et al., 2004) and Mt. Rainier (10.4 \pm 0.5 ka B.P.) (Heine, 1997). Following this cooling period, the sea surface temperature data suggests a warming, similar to modern temperature values, until approximately 8 ka B.P. (Barron et al., 2003). Between $3-8$ ka B.P., the Early-Neoglacial ELAs decreased $\sim 280 \mathrm{~m}$ at Three Sisters suggesting cooler summer temperature (0.7 $\left.1.6^{\circ} \mathrm{C}\right)$ and wetter winters $(40-100 \mathrm{~cm}$ weq.). This is consistent with SST records that were $1-2^{\circ} \mathrm{C}$ cooler during the summer (Barron et al., 2003). This cooling and wetting continued to approximately 3.5 ka B.P. until the temperature began to rise to modern values (Barron et al., 2003). Since, two minor summer cooling intervals of $0.2-1.0^{\circ} \mathrm{C}$ and winter precipitation increases of $10-60 \mathrm{~cm}$ weq. at $2,000-3,000(?)$ and $100-500$ years ago have disrupted this warm and dry interval during the late Holocene. Because the moraines from the Late-Neoglacial are few, it is difficult to decipher the ELA depression. However, the LIA moraines are very apparent and average summer temperature would have been $0.2-1.0^{\circ} \mathrm{C}$ lower than present during the LIA to accommodate the $80 \mathrm{~m}$ difference between the modern and LIA ELAs. This is consistent with LIA global temperature cooling (Jones and Bradley, 1992) and local tree ring records (Wiles et al., 1996). These mid and late Holocene advances are 
locally correlative with similar glacial events in the Mt. Hood (Lillquist, 1988), Mt. Jefferson (Scott, 1977), Mt. McLoughlin (Carver, 1972), and Mountain Lakes Wilderness (Carver, 1972) areas.

\subsection{Suggestions for Future Work}

The timing of glacial advances in the Three Sisters Wilderness is still relatively unknown. The majority of the glacial deposits have been dated using relative techniques, such as soil thicknesses and stratigraphic positions relative to tephras and lava flows. In most cases, these techniques are only precise to within $\pm 3000-5000$ yrs. precluding accurate correlation with advances/stands in other regions of western North America. Future research in the Three Sister Wilderness should include a rigorous attempt to find suitable material to date the glacial deposits and correlate their timing with other advances of western North America. This will aid in the refinement of regional and global climate models and will help in understanding how Oregon was affected by global climate anomalies (i.e. Younger Dryas and Heinrich events). Additionally, further detailed mapping of the Pleistocene and Holocene glacial deposits throughout Oregon is needed to help understand the magnitude of glaciation during the past $20 \mathrm{ka}$. 


\section{Works Cited:}

Anderson, L.W., and Anderson, D.S., 1981, Weathering rinds on quartzarenite clasts as a relative age indicator and the glacial chronology of Mount Timpanogos, Wasatch Range, Utah: Arctic and Alpine Research, v. 13, p. 25-31.

Bacon, C.R., 1983, Eruptive history of Mount Mazama and Crater Lake Caldera, Cascade Range, U.S.A.: Journal of Volcanology and Geothermal Research, v. 18, p. $57-115$.

Barron, J.A., Heusser, L., Herbert, T., and Lyle, M., 2003, High resolution climatic evolution of coastal northern California during the past 16,000 years:

Paleoceanography, v. 18, p. 20-1 to 20-14.

Benn, D.I., and Gemmell, A.M.D., 1997, Calculating equilibrium-line altitudes of former glaciers by the balance ratio method: a new computer spreadsheet http://boris.qub.ac.uk/ggg/papers/full/1997/tn011997/tn01.html: Glacial Geology and Geomorphology, 2005.

Berglund, B.E., 1979, The deglaciation of southern Sweden 13,500 - 10,000 B.P.: Boreas, v. 8, p. 89-117.

Bevis, K.A., 1995, Reconstruction of Late Pleistocene Paleoclimatic Characteristics in the Great Basin and Adjacent Areas [PhD. Dissertation]: Corvallis, Oregon State University. 
Bilderback, E.L., 2004, Timing and Paleoclimatic Significance of Latest Pleistocene and Holocene Cirque Glaciation in the Enchantment Lakes Basin, North Cascades, WA [Masters thesis]: Bellingham, Western Washington University.

Burrows, R.A., Kovanen, D.J., Easterbrook, D.J., and Clark, D.H., 2000, Timing and extent of cirque glaciation near Mts Baker and Shuksan, North Cascade Range: Geological Society of America Abstracts with Program, v. 32.

Carver, G.A., 1972, Glacial Geology of the Mountain Lakes Wilderness and adjacent parts of the Cascade Range, Oregon [ $\mathrm{PhD}$. Dissertation]: Seattle, University of Washington.

Clark, C.D., 1997, A new alpine lacustrine sedimentary record from the Sierra Nevada: Implications for Late-Pleistocene paleoclimate reconstructions and cosmogenic isotope production rates: EOS, Transactions American Geophysical Union, v. 78, p. F249.

Clark, D.H., and Gillespie, A.R., 1997, Timing and significance of late-glacial and Holocene cirque glaciation in the Sierra Nevada, California: Quaternary International, v. $38 / 39$, p. $21-38$.

Clark, P.U., and Bartlein, P.J., 1995, Correlation of late Pleistocene glaciation in the western United States with North Atlantic Heinrich events: Geology, v. 23, p. 483486. 
Crandell, D.R., 1969, Surficial geology of Mount Rainier National Park, Washington: U.S. Geological Survey Bulletin 1288.

Dethier, D.P., 1980a, Reconnaissance study of Holocene glacier fluctuations in the Broken Top Area, Oregon (abstract): Geological Society of America Abstracts with Program, v. 11, p. 104.

Dethier, D.P., 1980b, Reconnaissance study of Holocene glacier fluctuations in the Three Sisters Area, Oregon: EOS, Transactions, v. 61, p. 69.

Dorn, R.I., Turrin, B.D., Jull, A.J.T., Linick, T.W., and Donahue, D.J., 1987, Radiocarbon and cation-ratio ages for rock varnish on Tioga and Tahoe morainal boulders of Pine Creek, Eastern Sierra Nevada, California, and their paleoclimatic implications: Quaternary Researh, v. 28, p. 38-49.

Driedger, C.L., and Kennard, P.M., 1986, Ice Volumes on Cascade Volcanoes: Mount Rainier, Mount Hood, Three Sisters, and Mount Shasta: U.S. Geological Survey Professional Paper 1365, p. 28.

Furbish, D.J., and Andrews, J.T., 1984, The use of hypsometry to indicate long-term stability and response of valley glaciers to changes in mass transfer: Journal of Glaciology, v. 30, p. 199-211.

Garfin, G.M., and Hughes, M.K., 1996, Eastern Oregon Divisional Precipitation and Palmer Drought Severity Index from Tree-Rings, Report to the U.S. Forest Service 
Intermountain Research Station, USDA Forest Service Cooperative Agreement PNW $90-174$.

GEO, 2005, Oregon Geospatial Enterprise Office, http://www.oregon.gov/DAS/IRMD/GEO/standards/standards.shtml, April, 2005.

Grigg, L.D., and Whitlock, C., 1998, Late-glacial vegetation and climatic change in western Oregon: Quaternary Research, v. 49, p. 287-298.

Heine, J.T., 1997, Glacier advances at the Pleistocene/Holocene transition near Mount Rainier volcano, Cascade Range, USA: Seattle, University of Washington.

Hostetler, S.W., Bartlein, P.J., Clark, P.U., Small, E.E., and Solomon, A.M., 2000, Simulated influences of Lake Agassiz on the climate of central North America 11,000 years ago: Science, v. 405, p. 334-337.

Jones, P.D., and Bradley, R.S., 1992, Climatic variations in the longest instrumental records, in Bradley, R.S., and Jones, P.D., eds., Climate Since A.D. 1500: London, Routledge, p. 246-268.

Kotlyakov, V.M., and Krenke, A.N., 1982, Investigation of the hydrological conditions of alpine regions by glaciological methods: International Association of Hydrological Sciences Publications, v. 138, p. 31-42.

LaFrenz, M.D., 2001, The Neoglacial History of Mt. Thielsen, southern Oregon Cascades [M.S. thesis]: Portland, Portland State University. 
Larsen, S.J., Longva, O., and Mangerud, J., 1984, Allerod-Younger Dryas climatic inferences from cirque glaciers and vegetational development in the Nordfjord area, western Norway: Arctic and Alpine Research, v. 16, p. 137-160.

Leonard, K.C., 1989, Climatic change in the Colorado Rocky Mountains: estimates based on modern climate at Late Pleistocene equilibrium lines: Arctic and Alpine Research, v. 21, p. 245-255.

Licciardi, J.M., Clark, P.U., Brook, E.J., Elmore, D., and Sharma, P., 2004, Variable responses of western U.S. glaciers during the last deglaciation: Geology, v. 32, p. 8184.

Licciardi, J.M., Clark, P.U., Brook, E.J., Pierce, K.L., Kurz, M.D., Elmore, D., and Sharma, P., 2001, Cosmogenic ${ }^{3} \mathrm{He}$ and ${ }^{10} \mathrm{Be}$ chronologies of the late Pinedale northern Yellowstone ice cap, Montana, USA: Geology, v. 29, p. 1095-1098.

Lillquist, K.D., 1988, Holocene Fluctuations of the Coe Glacier, Mount Hood, Oregon [Masters thesis]: Portland, Portland State University.

Loewe, F., 1971, Considerations on the origin of the Quaternary Ice Sheet of North America: Arctic and Alpine Research, v. 3, p. 331-344.

Lorius, C., Jouzel, J., Ritz, L., Merlivat, L., Barkov, N.I., Korotkevitch, Y.S., and Kotlyakov, V.M., 1985, A 150,000-year climatic record from Antarctica ice: Nature, v. 316 , p. $591-596$. 
Lowe, J.J., and Walker, M.J.C., 1997, Reconstructing Quaternary Environments: Essex, Addison Wesley Longman Limited, 446 p.

Madsen, D.B., and Currey, D.R., 1979, Late Quaternary glacial and vegetation changes, Little Cottonwood Canyon area, Wasatch Mountains, Utah: Quaternary Research, v. 12, p. 254-270.

Mangerud, J., 1987, The Allerod/Younger Dryas boundary, in Berger, W.H., and Labeyrie, L.D., eds., Abrupt Climatic Change: Reidel, Dordrecht, p. 163-171.

Meier, M.F., and Post, A.S., 1962, Recent variations in mass net budgets in western North America: IUGG/IASH committee on Snow and Ice, General Assembly, v. 58, p. 63-77.

Menounos, B., Koch, J., Osborn, G., Clague, J.J., and Mazzucchi, D., 2004, Early Holocene glacier advance, southern Coastal Mountains, British Columbia, Canada: Quaternary Science Reviews, v. 23, p. 1543-1550.

Miller, C.D., 1969, Chronology of Neoglacial moraines in the Dome Peak area, North Cascade, Washington: Arctic and Alpine Research, v. 1, p. 49-66.

NRCS, 2005, Natural Resources Conservation Service, www.wcc.nrcs.usda.gov, April, 2005. 
O'Connor, J.E., Hardison, J.H.I., and Costa, J.E., 2001, Debris flows from failure of Neoglacial age moraine dams in the Three Sisters and Mount Jefferson Wilderness Area, Oregon: U.S. Geological Survey Professional Paper 1606, p. 93.

Ohmura, A., Kasser, P., and Funk, M., 1992, Climate at the equilibrium line of glaciers: Journal of Glaciology, v. 38, p. 397-411.

Owen, L.A., Finkel, R.C., Minnich, R.A., and Perez, A.E., 2003, Extreme southwestern margin of late Quaternary glaciation in North America: Timing and controls: Geology, v. 31, p. $729-732$.

Patterson, W.S., 2001, The Physics of Glaciers: Boston, Butterworth Heinemann, 481 p.

Phillips, F.M., Zreda, M.G., Benson, L.V., Plummer, M.A., Elmore, D., and Sharma, P., 1996, Chronology for fluctuations in late Pleistocene Sierra Nevada glaciers and lakes: Science, v. 274, p. 749-751.

Porter, S.C., 1977, Present and past glaciation threshold in the Cascade Range, Washington, U.S.A.: Topographic and climatic controls, and paleoclimatic implications: Journal of Glaciology, v. 18, p. 101-116.

Porter, S.C., 2004, Glaciation of western Washington, U.S.A., in Ehlers, J., and Gibbard, P.L., eds., Quaternary Glaciations - Extent and Chronology Part III: Seattle, Elsevier. 
Porter, S.C., Pierce, K.L., and Hamilton, T.D., 1983, Late Wisconsin mountain glaciation in the Western United States, in Porter, S.C., ed., Late-Quaternary Environments of the United States, Volume 1: Minneapolis, University of Minnesota Press, p. 71-111.

Porter, S.C., and Swanson, T.W., 1998, Radiocarbon age constraints on rates of advance and retreat of the Puget Lobe of the Cordilleran Ice Sheet during the last glaciation: Quaternary Research, v. 50, p. 205-213.

Reasoner, M.A., Osborn, G., and Rutter, N.W., 1994, Age of the Crowfoot advance in the Canadian Rocky Mountains: A glacial event coeval with Younger Dryas oscillation: Geology, v. 22, p. 439-442.

Scott, W.E., 1974, Quaternary Glacial and Volcanic Environments, Metolius River Area, Oregon [PhD. Dissertation]: Seattle, University of Washington.

Scott, W.E., 1977, Quaternary Glaciation and Volcanism, Metolius River area, Oregon: Geological Society of America Bulletin, v. 88, p. 113-124.

Scott, W.E., 1987, Holocene rhyodacite eruptions on the flanks of South Sister volcano, Oregon, in Fink, J.H., 1987, The Emplacement of Silicic Domes and Lava Flows, ed., Geological Society of America Special Paper 212.

Scott, W.E., 2005, p. Personal Communications. 
Scott, W.E., and Gardner, C.A., 1992, Geologic Map of Mount Bachelor Volcanic Chain and Surrounding Area, Cascade Range, Oregon, Map I-1967, U.S. Geological Survey.

Scott, W.E., Gardner, C.A., and Johnston, D.A., 1990, Field trip guide to the central Oregon High Cascades Part 1: Mount Bachelor-South Sister area: Oregon Geology, v. 52, p. 99-114.

Sherrod, D.R., Taylor, E.M., Ferns, M.L., Scott, W.E., Conrey, R.M., and Smith, G.A., in press, Geologic Map of the Bend 30- by 60-Minute Quadrangle Deschutes, Jefferson, Lane, Linn, and Cook Counties, Central Oregon, in U.S.G.S, ed., U.S. Geological Survey Investigation Map, Volume I-2683.

Sowers, T., Bender, M., Labeyrie, L.D., Jouzel, J., Raynaud, D., Martinson, D., and Korotkevitch, Y.S., 1993, 135,000 year Vostok - SPECMAP common temporal framework: Paleoceanography, v. 8, p. 737-766.

Stuiver, M., and Grootes, P.M., 2000, GISP2 oxygen isotope ratios: Quaternary Research, v. 53, p. 277-284.

Stuiver, M., and Reimer, P.J., 1993, Radiocarbon calibration program Calib Rev 4.4.2: Radiocarbon, v. 35, p. 215-230.

Sutherland, D.G., 1984, Modern glacier characteristics as a basis for inferring former climates with particular reference to the Loch Lomond Stadial: Quaternary Science Reviews, v. 3, p. 291-309. 
Taylor, E.M., 1990, Volcanic history and tectonic development of the Central High Cascade Range, Oregon: Journal of Geophysical Research, v. 95, p. 19,611-19,622.

Taylor, E.M., MacLeod, N.S., Sherrod, D.R., and Walker, G.W., 1987, Geologic Map of Three Sisters Wilderness, Deschutes, Lane, and Linn Counties, Oregon, Miscellaneous Field Studies Map (MF-1952), USGS.

Thackray, G.D., Lundeen, K.A., and Borgert, J.A., 2004, Latest Pleistocene alpine glacier advances in the Sawtooth Mountains, Idaho, USA: Reflections of midlatitude moisture transport at the close of the last glaciation: Geology, v. 32, p. 225-228.

Vacco, D.A., 2003, Developing Climate Records from Speleothems, Oregon Caves National Monument, Oregon [Masters thesis]: Corvallis, Oregon State University.

Wiles, G.C., D'Arrigo, R., and Jacoby, G.C., 1996, Temperature changes along the Gulf of Alaska and Pacific Northwest coast modeled from coastal tree-rings: Canadian Journal for Research, v. 26, p. 474-481.

Worona, M.A., and Whitlock, C., 1995, Late Quaternary vegetation and climate history near Little Lake, central Coast Range, Oregon: Geological Society of America Bulletin, v. 107, p. 867-876.

WRCC, 2005, Western Regional Climate Center, "Historical Climate Information", http://www.wrcc.dri.edu/, April, 2005. 


\section{Appendix: Detailed Stratigraphic Sections}

The following detailed, stratigraphic columns were collected during the summer of 2004. Color descriptions for each section are generalizations and should not be confused with the traditional Munsell soil classification. Particle sizes, sorting, and rounding were determined by hand. Sample numbers (labeled as sample numberlocation-date) correspond to archived soil and rock samples from each unit.

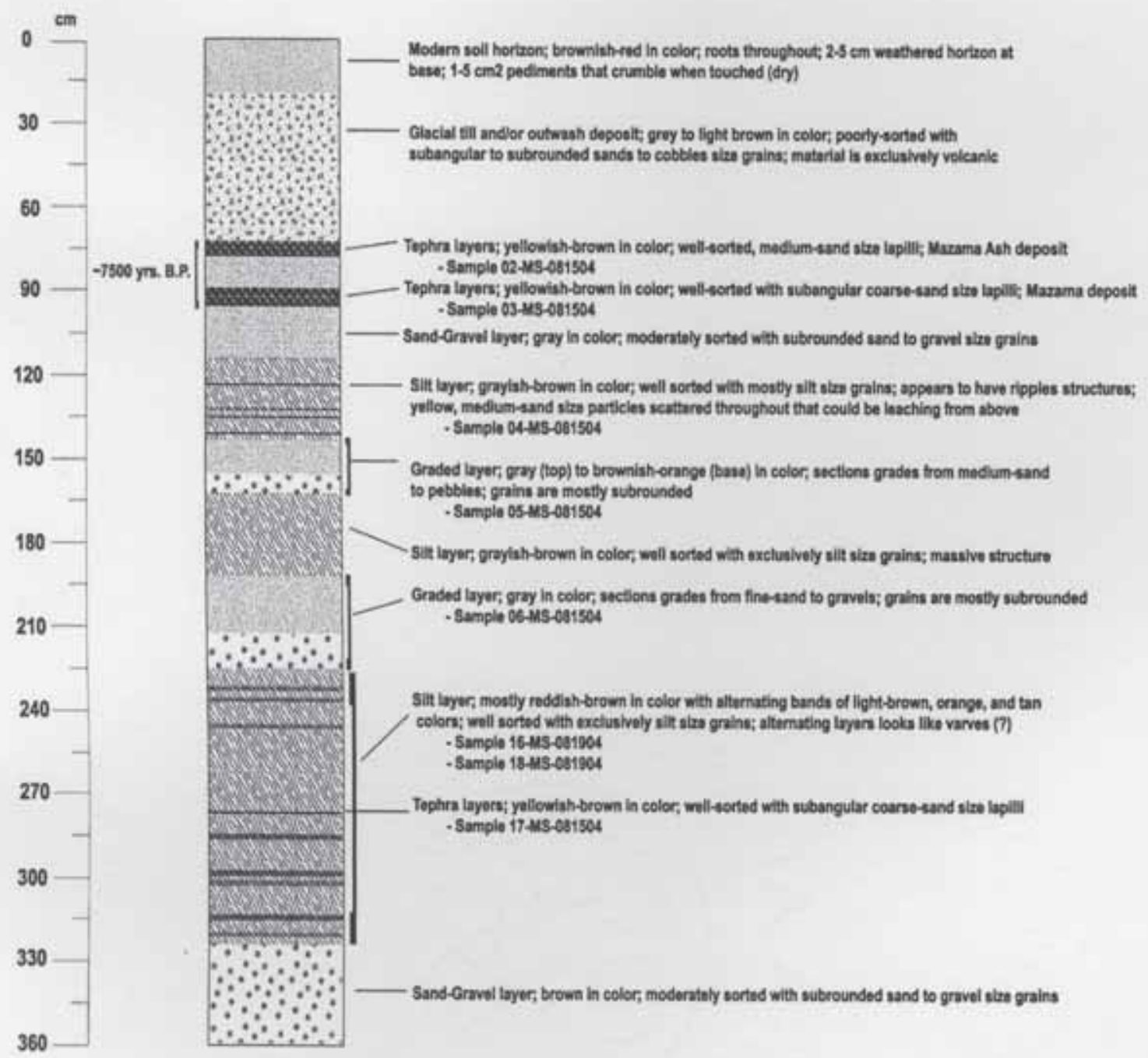

Figure 41: Detailed stratigraphic section of river exposure along the North Fork of Squaw Creek (Site 05) 


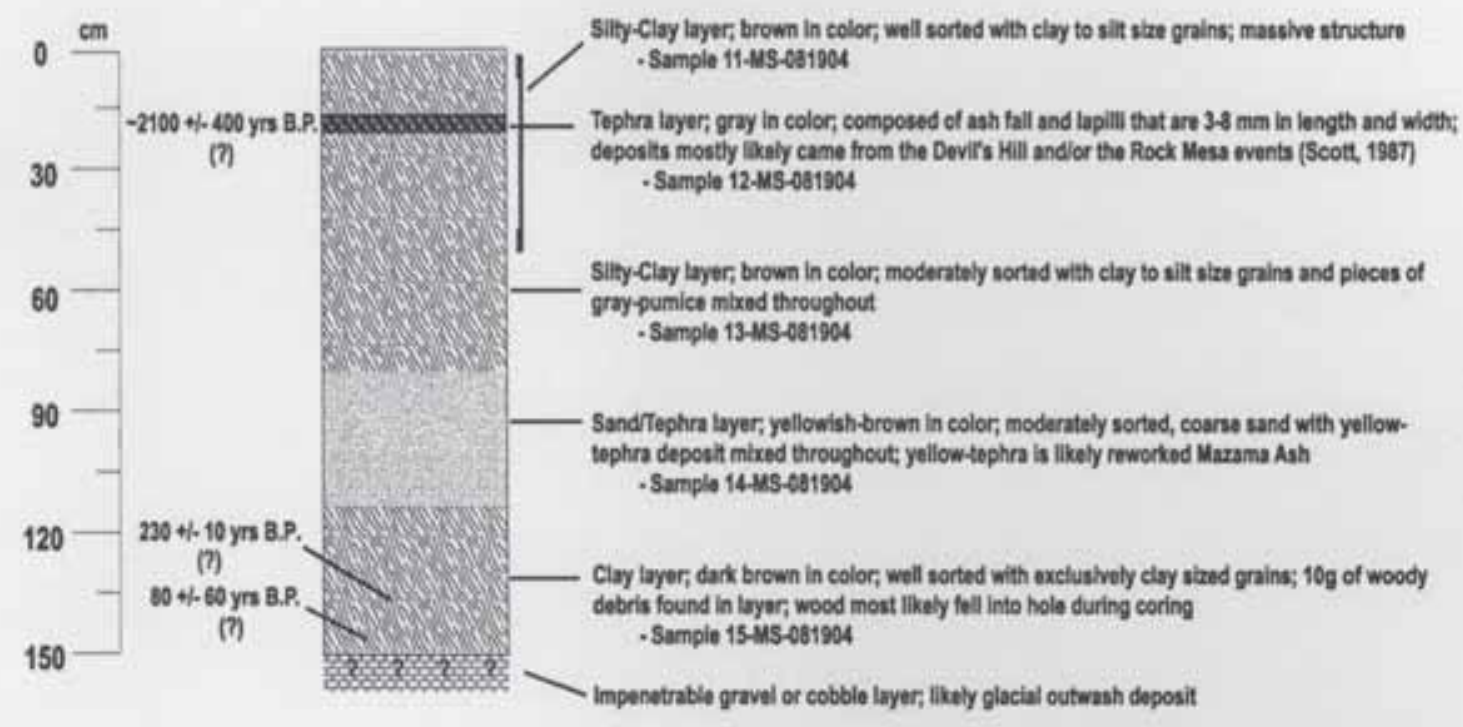

Figure 42: Detailed stratigraphic section of auger pit near Camp Lake between South and Middle Sisters (Site 16). Radiocarbon dates of $230 \pm 10 \mathrm{yrs}$ B.P. and $80 \pm 60 \mathrm{yrs}$. B.P. correspond to Beta numbers 203136 and 200871 , respectively. 


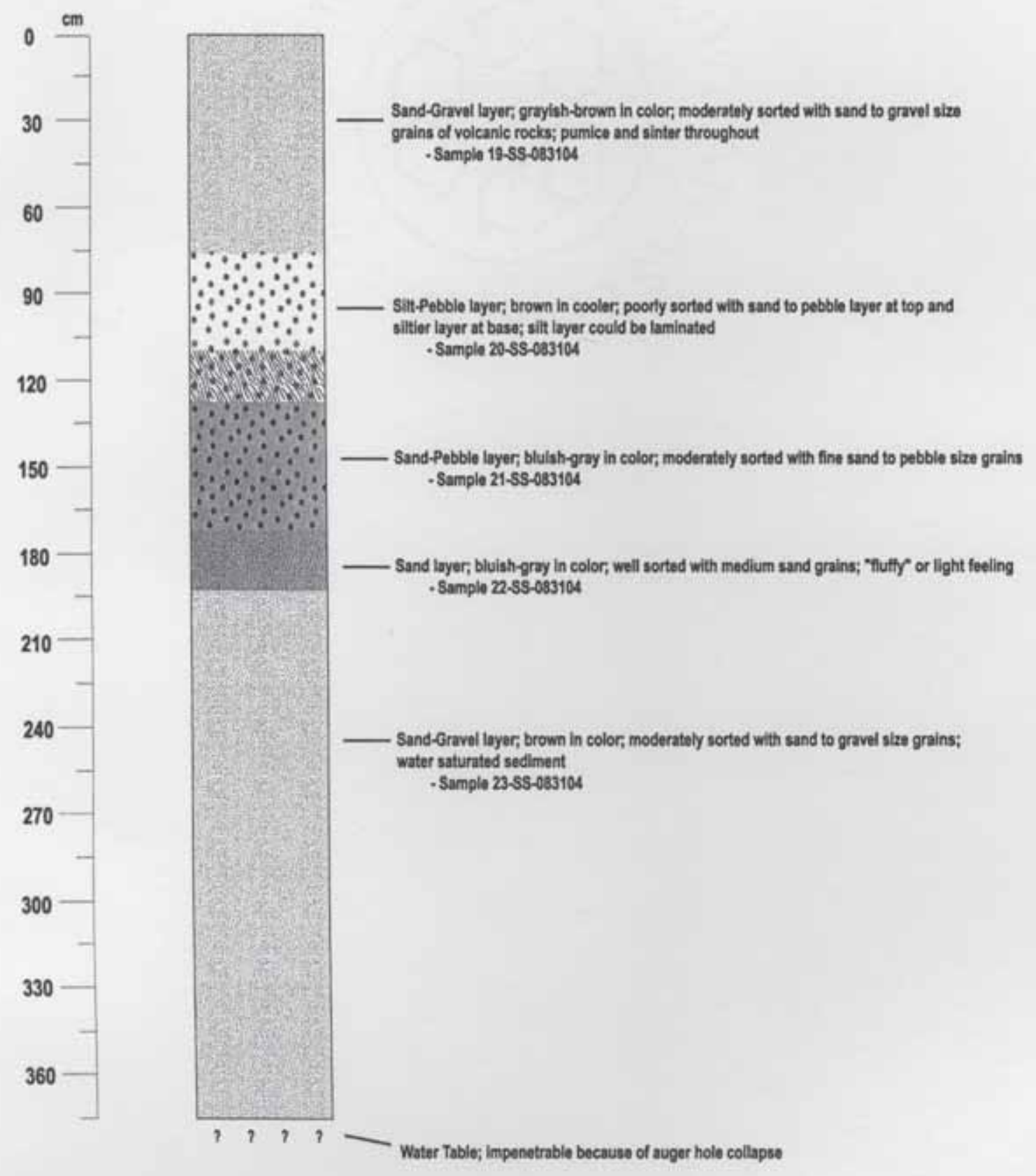

Figure 43: Detailed stratigraphic section of auger pit downslope of Carver Lake on South Sister (Site 18). 


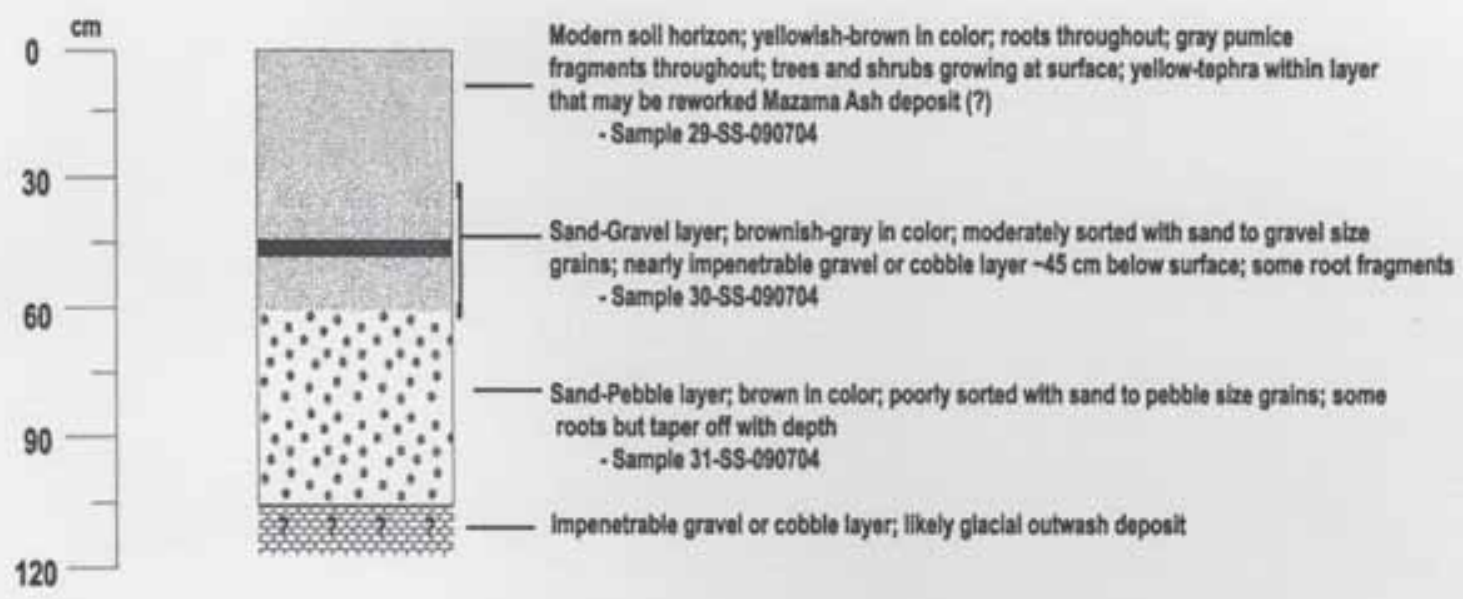

Figure 44: Detailed stratigraphic section of auger pit near Green Lake between South Sister and Broken Top Mountain (Site 20).

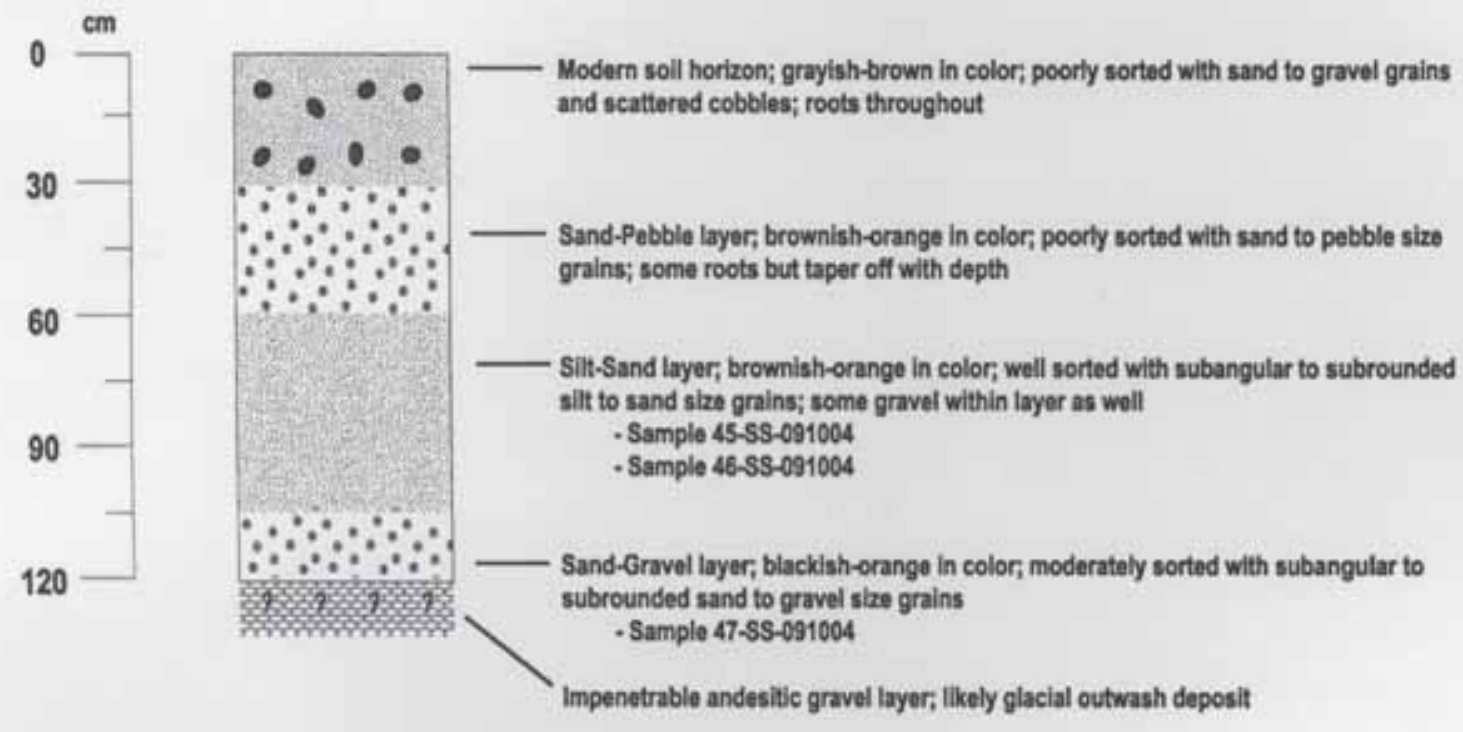

Figure 45: Detailed stratigraphic section of auger pit downslope of Prouty Glacier on South Sister (Site 24). 


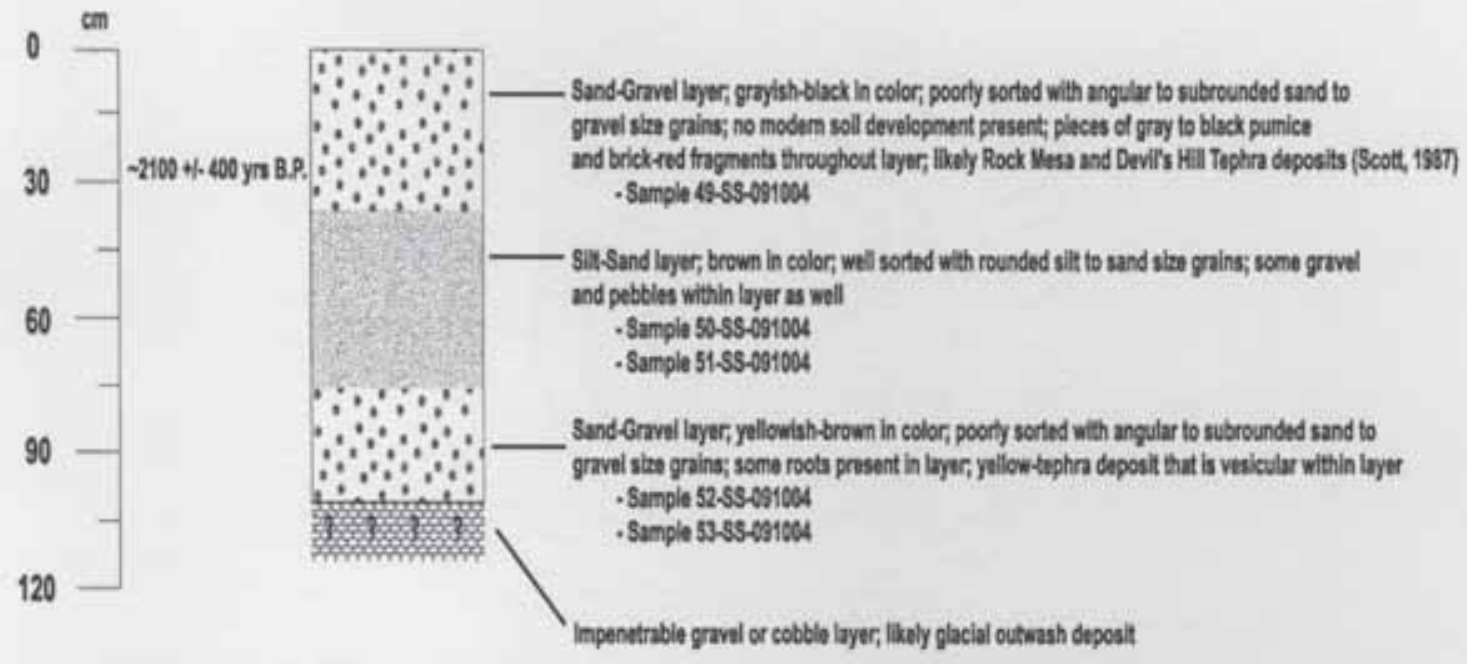

Figure 46: Detailed stratigraphic section of auger pit on saddle north of Green Lake (Site 27).

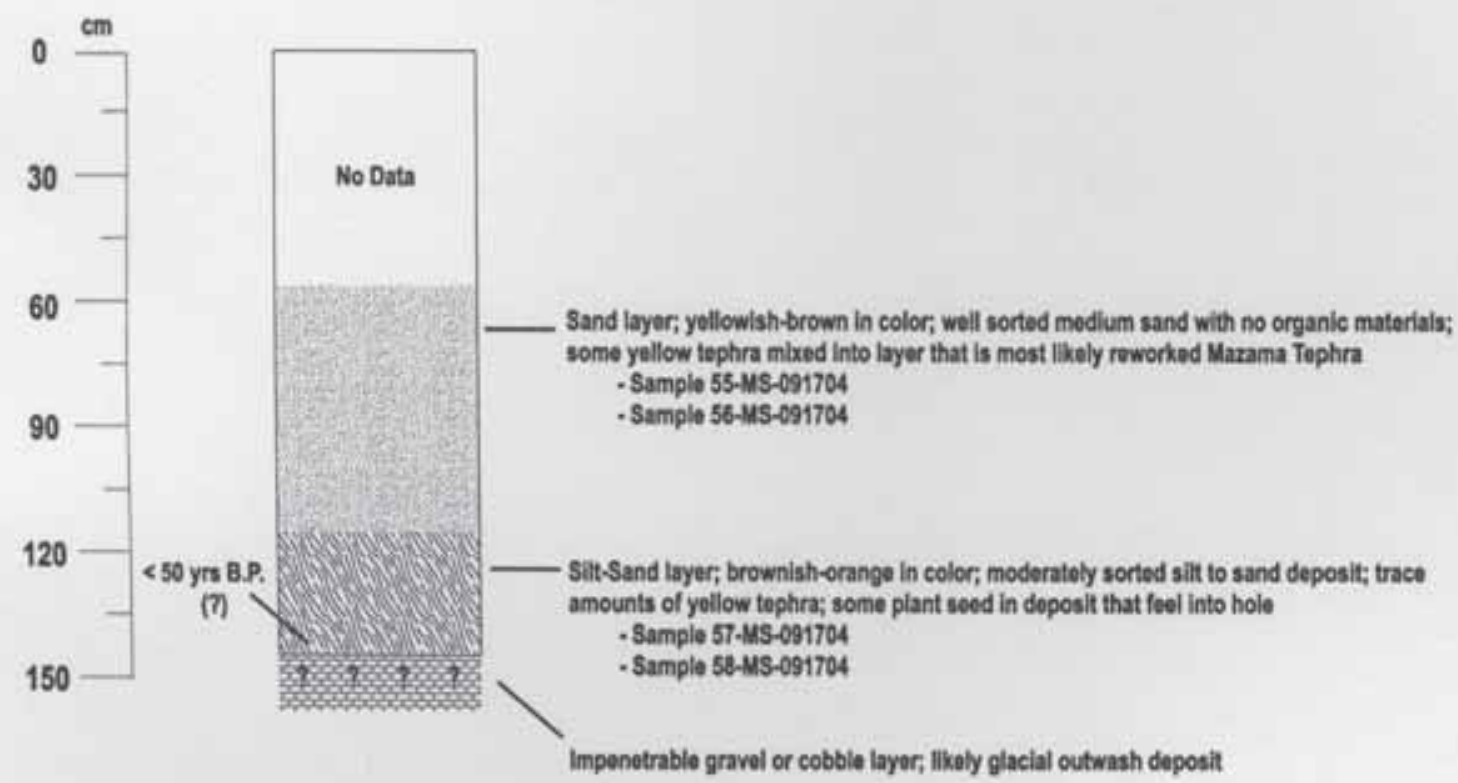

Figure 47: Detailed stratigraphic section of auger pit upslope of an apparent pre-Fountonnor moraine on Middle Sister (Site 32). Radiocarbon dates of $<50$ yrs B.P. corresponds to Beta numbers 200872. 


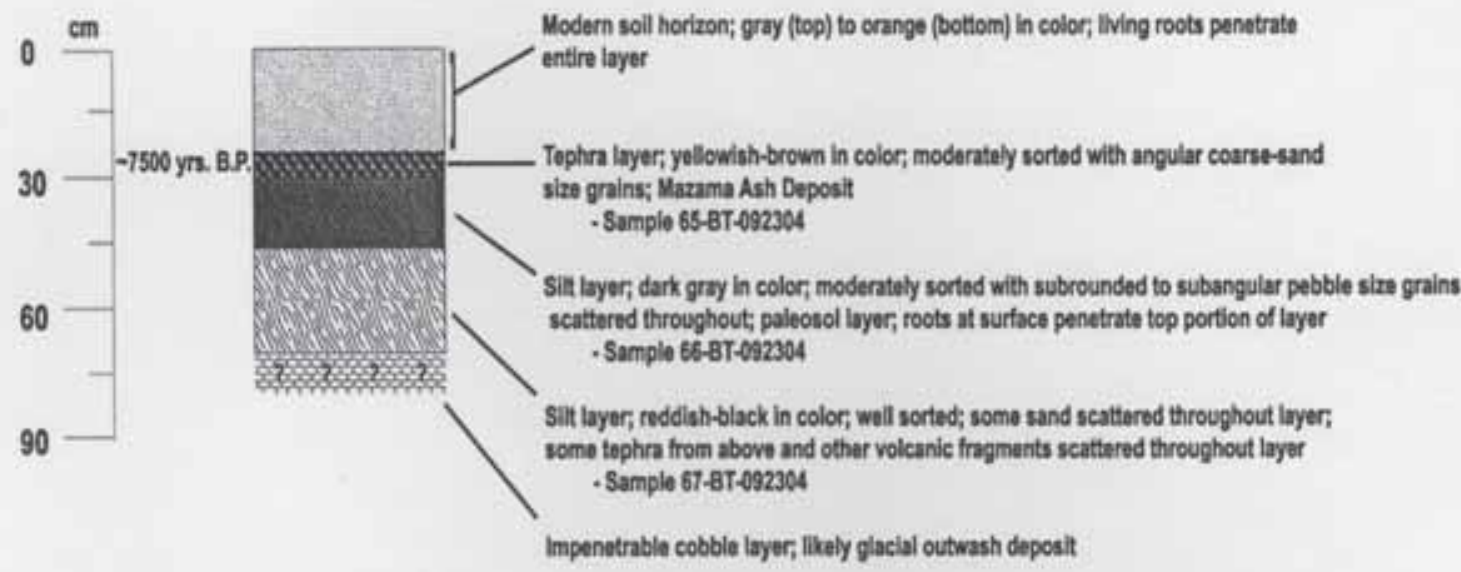

Figure 48: Detailed stratigraphic section of soil pit dug overlying a Fountonnor till or outwash deposit downslope of Broken Top (Site 41). 


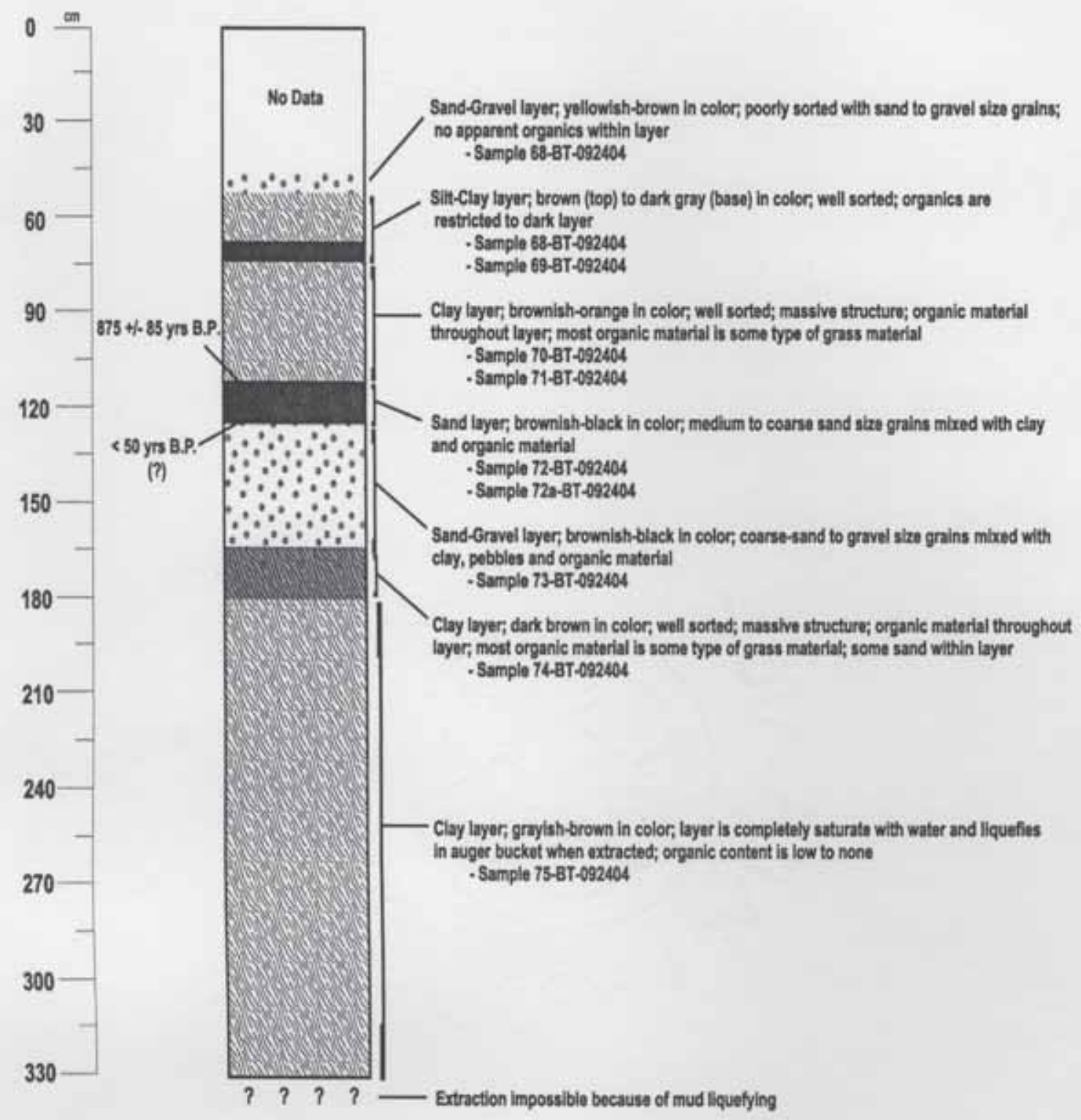

Figure 49: Detailed stratigraphic section of auger pit downslope of Bend Glacier on Broken Top (Site 43). Radiocarbon dates of $875 \pm 85$ yrs. B.P. and $<50$ yrs. B.P. correspond to Beta numbers 200873 and 203137 , respectively. 